\title{
Cochrane
}

Library

Cochrane Database of Systematic Reviews

\section{Interventions for latent autoimmune diabetes (LADA) in adults} (Review)

Brophy S, Davies H, Mannan S, Brunt H, Williams R

Brophy S, Davies H, Mannan S, Brunt H, Williams R.

Interventions for latent autoimmune diabetes (LADA) in adults.

Cochrane Database of Systematic Reviews 2011, Issue 9. Art. No.: CD006165.

DOI: 10.1002/14651858.CD006165.pub3.

www.cochranelibrary.com 
TABLE OF CONTENTS

HEADER 1

ABSTRACT

PLAIN LANGUAGE SUMMARY

SUMMARY OF FINDINGS

BACKGROUND

OBJECTIVES

METHODS

Figure 1.

RESULTS

Figure 2.

Figure 3.

DISCUSSION

Figure 4.

Figure 5.

AUTHORS' CONCLUSIONS

ACKNOWLEDGEMENTS

REFERENCES

CHARACTERISTICS OF STUDIES

DATA AND ANALYSES

Analysis 1.1. Comparison $1 \mathrm{HbA1c}$ mean difference in insulin compared to tablet, Outcome 1 Average mean difference in $\mathrm{HbA1c}$ from baseline to endpoint.

Analysis 1.2. Comparison $1 \mathrm{HbA} 1 \mathrm{c}$ mean difference in insulin compared to tablet, Outcome 2 Mean difference of HbA1c at study end point.

Analysis 2.1. Comparison 2 Sensitivity analysis, Outcome $1 \mathrm{HbA1c}$ at final point.

Analysis 2.2. Comparison 2 Sensitivity analysis, Outcome 2 Mean difference from baseline at study endpoint. ADDITIONAL TABLES

APPENDICES

WHAT'S NEW

CONTRIBUTIONS OF AUTHORS

DECLARATIONS OF INTEREST

SOURCES OF SUPPORT

DIFFERENCES BETWEEN PROTOCOL AND REVIEW

INDEX TERMS 
[Intervention Review]

\section{Interventions for latent autoimmune diabetes (LADA) in adults}

Sinead Brophy ${ }^{1}$, Helen Davies², Sopna Mannan², Huw Brunt ${ }^{3}$, Rhys Williams²

${ }^{1}$ College of Medicine, University of Wales, Swansea, Swansea, UK. ${ }^{2}$ School of Medicine, University of Wales, Swansea, Swansea, UK.

${ }^{3}$ National Public Health Service for Wales, Carmarthen, UK

Contact address: Sinead Brophy, College of Medicine, University of Wales, Swansea, Singleton Park, Swansea, Wales, SA2 8PP, UK. s.brophy@swansea.ac.uk.

Editorial group: Cochrane Metabolic and Endocrine Disorders Group.

Publication status and date: New search for studies and content updated (no change to conclusions), published in Issue 9, 2011.

Citation: Brophy S, Davies H, Mannan S, Brunt H, Williams R. Interventions for latent autoimmune diabetes (LADA) in adults. Cochrane Database of Systematic Reviews 2011, Issue 9. Art. No.: CD006165. DOI: 10.1002/14651858.CD006165.pub3.

Copyright @ 2011 The Cochrane Collaboration. Published by John Wiley \& Sons, Ltd.

\section{A B S T R A C T}

\section{Background}

Latent autoimmune diabetes in adults (LADA) is a slowly developing type 1 diabetes.

\section{Objectives}

To compare interventions used for LADA.

\section{Search methods}

Studies were obtained from searches of electronic databases, supplemented by handsearches, conference proceedings and consultation with experts. Date of last search was December 2010.

\section{Selection criteria}

Randomised controlled trials (RCT) and controlled clinical trials (CCT) evaluating interventions for LADA or type 2 diabetes with antibodies were included.

\section{Data collection and analysis}

Two authors independently extracted data and assessed risk of bias. Studies were summarised using meta-analysis or descriptive methods.

\section{Main results}

Searches identified 13,306 citations. Fifteen publications (ten studies) were included, involving 1019 participants who were followed between three months to 10 years (1060 randomised). All studies had a high risk of bias. Sulphonylurea (SU) with insulin did not improve metabolic control significantly more than insulin alone at three months (one study, $n=15$ ) and at 12 months (one study, $n=14$ ) of treatment and follow-up. SU (with or without metformin) gave poorer metabolic control compared to insulin alone (mean difference in glycosylated haemoglobin $\mathrm{A} 1 \mathrm{c}(\mathrm{HbA1c})$ from baseline to end of study, for insulin compared to oral therapy: $-1.3 \%(95 \%$ confidence interval $(\mathrm{Cl})-2.4$ to $-0.1 ; \mathrm{P}=0.03,160$ participants, four studies, follow-up/duration of therapy: 12, 30, 36 and 60 months; however, heterogeneity was considerable). In addition, there was evidence that SU caused earlier insulin dependence (proportion requiring insulin at two years was $30 \%$ in the SU group compared to $5 \%$ in conventional care group $(P<0.001)$; patients classified as insulin dependent was $64 \%$ (SU group) and $12.5 \%$ (insulin group, $\mathrm{P}=0.007$ ). No intervention influenced fasting C-peptide, but insulin maintained stimulated C-peptide better than SU (one study, mean difference $7.7 \mathrm{ng} / \mathrm{ml}(95 \% \mathrm{Cl} 2.9$ to 12.5$)$ ). In a five year follow-up of GAD65 (glutamic acid decarboxylase formulated with aluminium hydroxide), improvements in fasting and stimulated C-peptide levels ( $20 \mu \mathrm{g}$ group) were maintained after five years. Short term (three months) follow-up in one study $(n=74)$ using Chinese remedies did not demonstrate a significant difference in improving fasting C-peptide levels compared to insulin alone $(0.07 \mu \mathrm{g} / \mathrm{L}(95 \% \mathrm{Cl}-0.05$ to 0.19$)$. One study using vitamin D with insulin showed steady fasting C-peptide levels in the vitamin D group but declining fasting C-peptide levels ( 368 to $179 \mathrm{pmol} / \mathrm{L}, \mathrm{P}=0.006$ ) in the insulin alone group at 12 
months follow-up. Comparing studies was difficult as there was a great deal of heterogeneity in the studies and in their selection criteria. There was no information regarding health-related quality of life, complications of diabetes, cost or health service utilisation, mortality and limited evidence on adverse events (studies on oral agents or insulin reported no adverse events in terms of severe hypoglycaemic episodes).

\section{Authors' conclusions}

Two studies show SU leading to earlier insulin dependence and a meta-analysis of four studies with considerable heterogeneity showed poorer metabolic control if SU is prescribed for patients with LADA compared to insulin. One study showed that vitamin D with insulin may protect pancreatic beta cells in LADA. Novel treatments such as GAD65 in certain doses $(20 \mu \mathrm{g})$ have been suggested to maintain fasting and stimulated C-peptide levels. However, there is no significant evidence for or against other lines of treatment of LADA.

\section{PLAIN LANGUAGE SUMMARY}

\section{Interventions for latent autoimmune diabetes (LADA) in adults}

LADA is a condition that at diagnosis looks like type 2 diabetes (non-insulin requiring diabetes mellitus) but actually is a type 1 diabetes, where the patient will become insulin requiring. In the UK approximately $3.6 \%$ of people who look like they have type 2 diabetes actually have type 1 diabetes, while other studies suggest the prevalence is higher and treatment for these patients may need to be different from that used in type 2 diabetes.

We identified 15 publications (10 studies) looking at 1019 patients who were followed between three months to 10 years. We found many of the publications had poor quality of reporting and had small numbers of participants. However, there does seem to be evidence from this review that the drug sulphonylurea (like glibenclamide or glyburide, gliclazide) could make patients insulin dependent sooner and it does not control blood sugar as well as insulin. Therefore, this suggests that this drug should not be a first line treatment for patients with LADA. In addition, insulin combined with vitamin D, or Chinese herbs may maintain natural insulin production better than insulin alone. Similarly, glutamic acid decarboxylase (GAD65) may maintain natural insulin production. However, there was no conclusive evidence that any of the other remaining treatment methods were better than each other. Studies on oral agents or insulin reported no adverse events in terms of severe hypoglycaemic attacks.

This review represents very early days of our understanding of the best way to treat LADA. It is limited by the poor reporting quality of the studies, small sample sizes, no clear single definition of LADA and many of the studies being carried out in different ethnic groups (China, Japan, Cuba, UK, Sweden) with different clinical care systems.

None of the publications reported on complications of diabetes, health-related quality of life, costs or health service utilisation. All but one of the publications reported there were no deaths.

In summary, this review demonstrates that insulin treatment may be preferable compared to sulphonylurea treatment but there is little evidence regarding other forms of treatment. Future studies are needed, should have a clear definition of LADA, investigate patientimportant outcomes and use a common method of measuring stimulated C-peptide (a marker of natural insulin production reflecting improved beta-cell function of the pancreas). 


\begin{tabular}{|c|c|c|c|c|c|c|}
\hline \multicolumn{7}{|c|}{$\begin{array}{l}\text { S U M M A R Y O F F I N D I N G S } \\
\text { Summary of findings for the main comparison. }\end{array}$} \\
\hline \multicolumn{7}{|c|}{ Insulin compared with sulphonylurea compounds for latent autoimmune diabetes (LADA) in adults } \\
\hline \multirow{4}{*}{\multicolumn{7}{|c|}{$\begin{array}{l}\text { Patient or population: patients with LADA } \\
\text { Settings: Out-patients } \\
\text { Intervention: Insulin } \\
\text { Comparison: Oral antidiabetic drugs (sulphonylureas) }\end{array}$}} \\
\hline & & & & & & \\
\hline & & & & & & \\
\hline & & & & & & \\
\hline \multirow[t]{3}{*}{ Outcomes } & \multicolumn{2}{|c|}{ Illustrative comparative risks* $(95 \% \mathrm{Cl})$} & \multirow{3}{*}{$\begin{array}{l}\text { Relative ef- } \\
\text { fect } \\
(95 \% \mathrm{CI})\end{array}$} & \multirow{3}{*}{$\begin{array}{l}\text { No of Partici- } \\
\text { pants } \\
\text { (studies) }\end{array}$} & \multirow{3}{*}{$\begin{array}{l}\text { Quality of the } \\
\text { evidence } \\
\text { (GRADE) }\end{array}$} & \multirow[t]{3}{*}{ Comments } \\
\hline & Assumed risk & Corresponding risk & & & & \\
\hline & Sulphonylureas & Insulin & & & & \\
\hline $\begin{array}{l}\text { Development of diabetic } \\
\text { complications }\end{array}$ & See comment & See comment & Not estimable & - & See comment & $\begin{array}{l}\text { Not investigat- } \\
\text { ed }\end{array}$ \\
\hline $\begin{array}{l}\text { Adverse events } \\
\text { Follow-up: }\end{array}$ & See comment & See comment & Not estimable & (5 studies) & See comment & $\begin{array}{l}\text { Only } 5 \text { studies } \\
\text { reported data. }\end{array}$ \\
\hline \multicolumn{7}{|l|}{$12+$ months } \\
\hline Health-related quality of life & See comment & See comment & Not estimable & - & See comment & $\begin{array}{l}\text { Not investigat- } \\
\text { ed }\end{array}$ \\
\hline Death from any cause & See comment & See comment & Not estimable & - & See comment & $\begin{array}{l}\text { Not investigat- } \\
\text { ed }\end{array}$ \\
\hline $\begin{array}{l}\text { Health service utilisation } \\
\text { and costs }\end{array}$ & See comment & See comment & Not estimable & - & See comment & $\begin{array}{l}\text { Not investigat- } \\
\text { ed }\end{array}$ \\
\hline $\begin{array}{l}\text { HbA1c at study endpoint } \\
\text { Follow-up: } \\
12+\text { months }\end{array}$ & $\begin{array}{l}\text { The mean } \mathrm{HbAlc} \text { ranged } \\
\text { across control groups from } \\
7.3 \% \text { to } 11.2 \%\end{array}$ & $\begin{array}{l}\text { The mean change in } \mathrm{HbAlc} \text { in the } \\
\text { intervention group was } \\
1.3 \% \text { lower ( } 2.4 \% \text { lower to } 0.1 \\
\text { lower); }\end{array}$ & & $\begin{array}{l}160 \\
\text { (4 studies) }\end{array}$ & $\begin{array}{l}\oplus \oplus \oplus \ominus \\
\text { low } 1\end{array}$ & \\
\hline
\end{tabular}

*The basis for the assumed risk (e.g. the median control group risk across studies) is provided in footnotes. The corresponding risk (and its $95 \%$ confidence interval) is based on the assumed risk in the comparison group and the relative effect of the intervention (and its $95 \% \mathrm{Cl}$ ). 
GRADE Working Group grades of evidence

High quality: Further research is very unlikely to change our confidence in the estimate of effect.

Moderate quality: Further research is likely to have an important impact on our confidence in the estimate of effect and may change the estimate.

Low quality: Further research is very likely to have an important impact on our confidence in the estimate of effect and is likely to change the estimate.

Very low quality: We are very uncertain about the estimate.

1 considerable heterogeneity

HbA1c: glycosylated haemoglobin A1c 


\section{B A C K G R O U N D}

\section{Description of the condition}

Diabetes mellitus is a metabolic disorder resulting from a defect in insulin secretion, insulin action, or both. A consequence of this is chronic hyperglycaemia (that is elevated levels of plasma glucose) with disturbances of carbohydrate, fat and protein metabolism. Long-term complications of diabetes mellitus include retinopathy, nephropathy and neuropathy. The risk of cardiovascular disease is increased. For a detailed overview of diabetes mellitus, please see under 'Additional information' in the information on the Metabolic and Endocrine Disorders Group in The Cochrane Library (see Cochrane Review Groups (CRGs)'). For an explanation of methodological terms, see the main Glossary in The Cochrane Library.

Diabetes is normally classified into two major types: type 1 (insulindependent) diabetes and type 2 (non-insulin-dependent) diabetes. However, there is one form of diabetes which presents with noninsulin requiring diabetes in adults, but with many of the genetic, immune and metabolic features of type 1 diabetes and with a high risk of progression to insulin dependency. Latent autoimmune diabetes in adults (LADA) is a type 1 diabetes which shows slow progression to insulin dependence. A person with LADA will present clinically as an adult who is not insulin dependent at diagnosis. The patient will usually, therefore, be treated as having type 2 diabetes. However, LADA is an autoimmune condition unlike type 2 diabetes and therefore can be distinguished from type 2 diabetes by blood tests for antibodies. LADA is classified by the presence of pancreatic auto-antibodies, such as glutamic acid decarboxylase antibodies (GADA) in an adult initially presenting with non-insulin dependent diabetes. Officially, LADA is classified as type 1 diabetes mellitus by the World Health Organisation. There are different laboratory methods used in GADA analysis such as a radioactiveassay or an Elisa (enzyme linked immunosorbent assay). The GADA radioactive-assay has been shown to obtain $84 \%$ sensitivity and $94 \%$ specificity and varies in cost (Bingley 2003). The GADA Elisa has been reported as a sensitivity of $92 \%$ and a specificity of 99\% in the Diabetes Antibody Standardization Program (DASP) in 2003 (Bingley 2003). Compared to a person with type 2 diabetes, a person with LADA may be younger, thinner and usually insulin deficient rather than insulin resistant (Nabhan 2005). Numerous studies have attempted to establish the prevalence of LADA based on auto-antibody detection amongst adults with diabetes in both European and non-European countries. Recently, a study in the UK found that $3.6 \%$ (95\% confidence interval (CI) $2.1 \%$ to $6.1 \%$ ) of all newly diagnosed people with apparent type 2 diabetes have LADA (Davies 2008). Similarly, the ADOPT study (Zinman 2004) reported that GADA was detected in $4.7 \%$ of their North American cohort and in $3.7 \%$ of their European cohort. The Ehime study (Takeda 2002 ) in Japan also reported similar frequencies of GADA at 3.8\%. The UK Prospective Diabetes study (which recruited people from 25 centres in the UK) examined the number of patients with apparent type 2 diabetes ( $n=3672$ ) who were positive for islet cell antibodies (ICA) and GAD (Turner 1997). They found that $13 \%$ of 25 to 44 year old people were positive for ICA and GAD and of these $94 \%$ required insulin therapy by six years. However, the UKPDS started participant recruitment in 1977 and the number of people with type 2 diabetes has now increased. Another study (Owen 2003) examining 268 people with type 2 diabetes diagnosed age 18 to 45 years found $11.6 \%$ had potential LADA. Based on the latter figures, this means there are more people with LADA than with 'classical' type 1 diabetes. However, in the UK, GAD tests are not routinely performed and patients are treated as having type 2 diabetes, in other countries in Europe GAD tests are performed (Brophy 2006). However, there is much debate regarding the definition of LADA (Gale 2005; Leslie 2006; Stenstrom 2005). It is not clear if antibody positivity marks a distinct condition or simply a risk factor to insulin progression for a type 1 diabetes phenotype. The lack of a clear definition makes conclusions regarding a treatment strategy even more difficult.

\section{Description of the intervention}

Early studies in Japan (58 patients) (Kobayashi 1996; Maruyama 2003; Takino 1998) have suggested that patients with GAD antibodies should start insulin treatment within one year of diagnosis in order to maintain near norm-glycaemic control and this treatment could prevent slowly progressive pancreatic betacell failure. Patients taking insulin had an improved C-peptide response (this is a marker of natural insulin production and reflects improved beta-cell function), stable glycosylated haemoglobin A1c (HbA1c) values and reduced auto-antibody levels. These findings have been supported by studies in Cuba (Cabrera-Rode 2002) and China (Zhou 2004).

Oral agents like thiazolidinediones have anti-inflammatory activity and could potentially also be an effective treatment for patients in the non-insulin dependent stage of LADA (Beales 2002). Rosiglitazone has been given in combination with insulin and was found to maintain C-peptide levels better than insulin alone (Zhou 2004).

Sulphonylurea treatments may be harmful to people with LADA as they may deplete the already low reserves of insulin. LADA patients given sulphonylurea (with or without insulin) have persistent antibodies and poor fasting glucose concentrations compared to people on insulin alone (Kobayashi 2002; Takino 1998; Zhou 2004). This review aims to examine the effects of a range of interventions aimed at improving treatment in people with LADA.

\section{Interventions used in diabetes and adverse effects associated with these interventions}

Serious long-term complications can result such as eye complications, heart disease, kidney and foot problems if blood sugar levels are poorly controlled. Insulin is the primary treatment for all patients with type 1 diabetes and for type 2 diabetic patients who cannot adequately control their blood sugar by diet and exercise or oral hypoglycaemic agents, or both. However, insulin can cause hypoglycaemia (low blood sugar) and requires a change in life style. There are six major types of oral antidiabetic drugs and a new type of antidiabetic medication (injection) which are glucagon like peptide 1 (GLP-1) analogues (such as exenatide) and liraglutide (Amori 2007) that can be used to control blood sugar in type 2 diabetes; biguanides (metformin (Saenz 2005) is now the only one available), sulphonylureas (glibenclamide, gliclazide to name a few), thiazolidinediones, i.e. pioglitazone (Richter 2006) and rosiglitazone (Richter 2007), meglitinides (Black 2003) (nateglinide and repaglinide), acarbose (van de Laar 2006) and dipeptidyl peptide-4 (DPP-4) inhibitors (Richter 2008) (such as vildagliptin, sitagliptin and saxagliptin). The most common side effects of metformin (biguanides) are digestive in nature; feeling or being sick, diarrhoea, abdominal pain, loss of appetite and a metallic taste. Metformin can very rarely cause lactic acidosis in certain individuals at risk and 
can cause hypoglycaemia. Sulphonylureas can encourage weight gain, and because they stimulate insulin release they can cause hypoglycaemia, and can lead to early depletion of insulin, leading perhaps to earlier insulin requirement. Sulphonylureas can also cause mild gastroenterological disturbances. On rare occasions they may cause allergic reactions. The most common side effects of the thiazolidinediones are weight gain, oedema and congestive heart failure. Infrequently, they may cause liver problems. Recently, the drug rosiglitazone was taken off the market in Europe and has severe restrictions in the US due to cardiovascular morbidity associated with its use. Side effects of meglitinides are rare, but include hypoglycaemia, mild digestive side effects and allergic reactions. The main side effect associated with acarbose is flatulence. All these interventions should be avoided in people with kidney or liver problems. Side effects of DPP-4 inhibitors in particular sitagliptin include upper respiratory tract infections, headaches, and diarrhoea. The GLP-1 analogues most common reported side effects are nausea and abdominal fullness.

\section{Why it is important to do this review}

This is an update of the systematic review conducted in 2006 and no other systematic reviews have been conducted on this topic to date. However, a number of reviews and editorial articles exist (Appel 2009; Nabhan 2005; Naik 2003; Naik 2009; Palmer 2002; Pozzilli 2001; Schernthaner 2001) . These suggest that there is no established intervention strategy for patients with LADA. Also, there are new clinical therapies being used in the management of people with diabetes since the last review.

\section{O B JECT IVES}

To compare interventions used for latent autoimmune diabetes in adults (LADA).

\section{METHODS}

\section{Criteria for considering studies for this review}

\section{Types of studies}

Studies were included if they were randomised controlled trials (RCT) or controlled clinical trials (CCT).

\section{Types of participants}

Adults (age 18 years and over) diagnosed with latent autoimmune diabetes in adults (LADA) or those diagnosed with type 2 diabetes with islet autoantibodies.

This review excludes interventions specifically addressed at children, adolescents, people with type 2 diabetes without antibodies or those diagnosed with type 1 diabetes and insulin treated at diagnosis. Those specifically diagnosed with type 1 diabetes (presence of ketones, insulin dependent for life) were defined within this review as having 'classical' type 1 diabetes and not LADA. It is know that in these patients insulin at diagnosis is the only treatment. This review is intended to examine the best treatment for patients who have type 1 diabetes but are not insulin dependent at diagnosis.

\section{Diagnostic criteria}

The diagnosis of LADA may differ between studies. Patients classified as LADA within a study are included and assumed to have LADA. However, a record of each definition for LADA from each study was included to give a summary of the different classification methods currently in use within the literature. The way LADA is classified will influence the characteristics of the people selected as 'LADA'. For example, selecting patients with high glutamic acid decarboxylase (GAD) levels will favour the leaner, younger patient with other autoimmune conditions; selecting patients who have not been treated with insulin for more than 12 months will select those with low GAD titre's, more insulin resistance and higher body mass index (Lohmann 2001).

\section{Types of interventions}

\section{Intervention}

Interventions aimed at treating LADA including: oral antidiabetic agents, insulin, diet, exercise and other possible 'life style' changes

\section{Control}

- no treatment;

- diet;

- placebo;

- another intervention aimed at LADA (e.g. insulin compared to a sulphonylurea compound).

No minimum duration of intervention or follow-up was defined.

\section{Types of outcome measures}

\section{Primary outcomes}

- development of complications (diabetic retinopathy, diabetic neuropathy, diabetic cardiovascular disease, diabetic nephropathy);

- metabolic control: glycosylated haemoglobin A1c (HbA1c) levels, fasting glucose and progression to insulin therapy;

- adverse events (such as hypoglycaemia episodes, ketoacidosis).

\section{Secondary outcomes}

- C-peptide levels;

- health service utilisation and costs;

- health-related quality of life (ideally, measured using a validated instrument);

- hypertension;

- hyperlipidaemia;

- lipid profile;

- microalbuminuria;

- total mortality.

\section{Timing of outcome measure}

Short term: 0 to 6 months.

Medium term: more than 6 to 12 months.

Long term: more than 12 months.

There was no minimum trial follow-up duration.

\section{Potential covariates, effect modifiers, confounders}

Time from diagnosis (disease duration), definition of LADA, level of antibody positivity, age of patient, ethnicity and gender. 


\section{Search methods for identification of studies}

\section{Electronic searches}

The following electronic databases were searched:

- The Cochrane Library (Issue 4, 2010);

- Dissertation Abstracts (up to 2010);

- EMBASE (up to 2010);

- ISI Science Citation Index (up to 2010);

- MEDLINE (up to 2010);

- PREMEDLINE (up to 2010);

- National Research Register (up to 2010);

- SIGLE (System for Information on Grey Literature) (up to 2010);

- BIDS (up to 2010);

- British Nursing Index (up to 2010);

- Applied Social Science database (ASSIA) (up to 2010);

- Caredata abstracts (up to 2010).

- Social Services Abstracts (up to 2010);

- Web of Knowledge (up to 2010).

The year limitation within the search was from January 1990 to December 2010. The term latent autoimmune diabetes in adults (LADA) was introduced in a paper published in 1993, and was defined as adult diabetic patients initially non-insulin-requiring but with immune markers of type 1 diabetes that, in a number of cases, progress to insulin dependency (Tuomi 1993).

We also searched databases of ongoing trials: Current Controlled Trials (www.controlled-trials.com - with links to other databases of ongoing trials).
For detailed search strategies please see under Appendix 1.

\section{Searching other resources}

Conference proceedings (American Diabetes Association (ADA), European Association for the Study of Diabetes (EASD) and Diabetes UK) and reference lists of studies and reviews identified were systematically searched, and lead researchers identified and contacted for the identification of relevant unpublished studies. Manual hand searching of Diabetes Care, Diabetic Medicine and Diabetologia was undertaken for the years 1990 to 2010.

\section{Data collection and analysis}

\section{Selection of studies}

Two authors (HD and SB) independently scanned the titles and abstract sections of every record retrieved. Full articles were retrieved for further assessment if the information suggested that the study:

- included patients with latent autoimmune diabetes in adults (LADA);

- evaluated an intervention.

Wherever there was any doubt regarding the existence of these criteria, the complete article was retrieved for clarification. Interrater agreement for study selection was measured using the kappa score (Cohen 1960). Any difference of opinion was discussed and, if necessary, resolved by a third party (RW). If the authors did not agree, a third person (RW) adjudicated. Studies were chosen for further examination if they met the inclusion criteria, or if the authors were in any doubt that they might meet the inclusion criteria. A PRISMA (preferred reporting items for systematic reviews and meta-analyses) flow-chart of study selection (Figure 1) is attached (Liberati 2009). 
Figure 1. Study flow diagram.

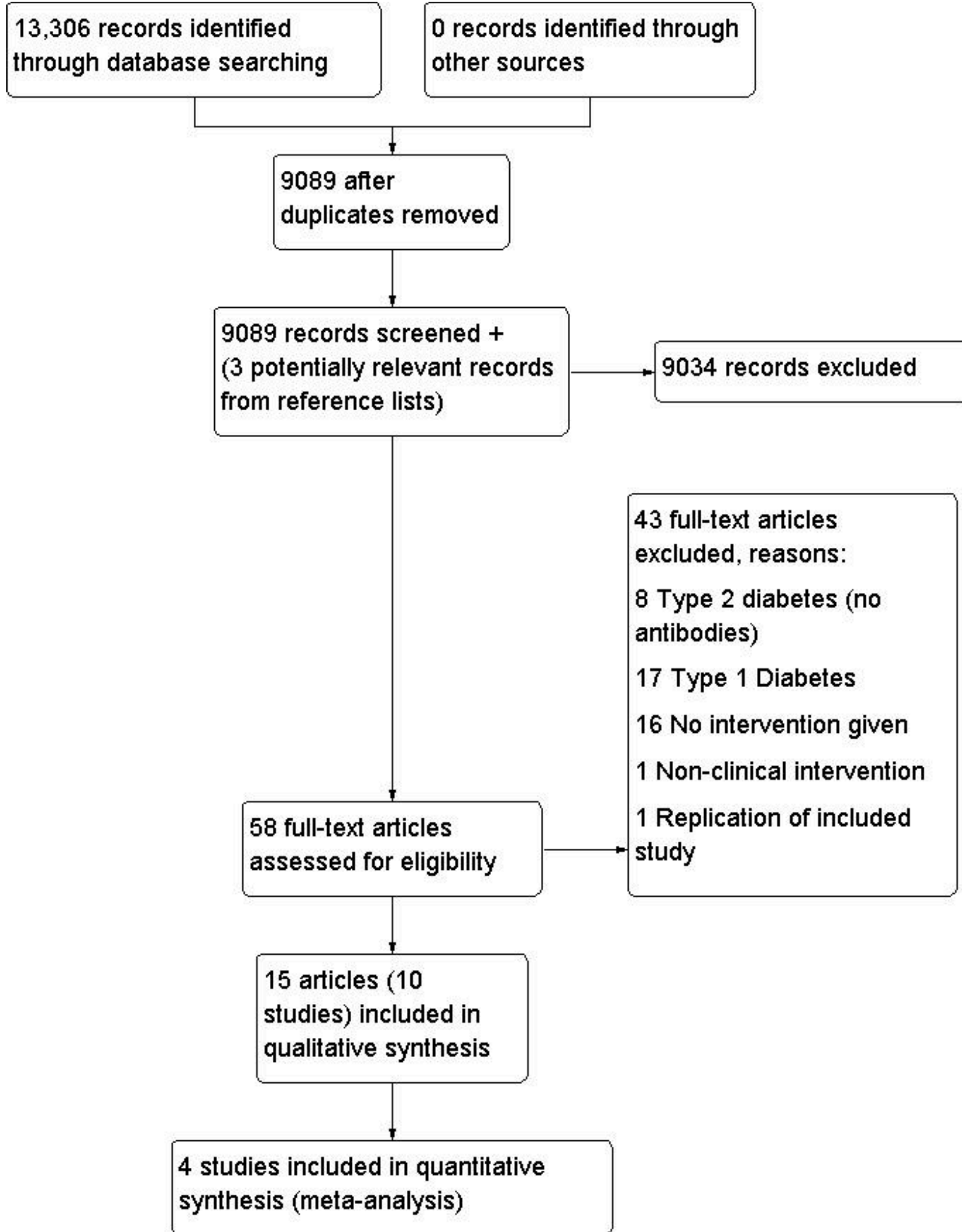




\section{Data extraction and management}

Data were extracted using standard data extraction forms provided by the Cochrane Metabolic and Endocrine Disorders Group (for details see Characteristics of included studies and Table 1, Appendix 2). We recorded country of origin, year of study, LADA definition used, average disease duration of participants, average age of participants, intervention used, glycosylated haemoglobin Alc $(\mathrm{HbAlc})$, fasting glucose and C-peptide at baseline and at specific time periods after intervention or placebo, as well as antibody measures. Data extraction and data entry were performed independently in duplicate by two evaluators (SB, SM, HD or HB). Differences in data extraction were discussed, and if necessary, resolved by consensus by a third independent author. If data were missing in a published report, the authors contacted the corresponding author.

\section{Dealing with duplicate publications}

In the case of duplicate publications and companion papers of a primary study, we tried to maximise yield of information by simultaneous evaluation of all available data. We had one case of a duplicate publication. In this case the original publication (the oldest version) obtained priority.

\section{Assessment of risk of bias in included studies}

Two independent authors (SB, HD) assessed the risk of bias of the included studies. As recommended by the Cochrane Handbook for Systematic Reviews of Interventions (Higgins 2011), the following methodological domains were assessed.

Sequence generation - was the method used to generate the allocation sequence appropriate to produce comparable groups?

Allocation sequence concealment - was the method used to conceal the allocation sequence appropriate to prevent the allocation being known in advance of, or during, enrolment?

Blinding of participants, personnel and outcome assessors - were measures used to blind study participants, personnel, and outcome assessors from knowledge of which intervention a participant received?

Incomplete outcome data - how complete were the outcome data for the primary outcomes? Were drop-out rates and reasons for withdrawal reported? Were missing data imputed appropriately? We considered an overall completion rate of $80 \%$ or higher as a low risk of bias. If completion rates were only provided by group, a less than $80 \%$ completion rate in the treatment group was considered a high risk of bias.

Selective outcome reporting - were appropriate outcomes reported and were any key outcomes missing?

Other potential threats to validity (considering external validity, e.g. relevant use of co-interventions) - what was the funding source of each of the studies?

We explicitly judged each of these criteria. Two authors (HD or $\mathrm{SB}$ or SM or HB) assessed each trial independently. Possible disagreement was resolved by consensus, or with consultation of a third party in case of disagreement. We planned to explore the influence of individual quality criteria in a sensitivity analysis (see under 'sensitivity analyses'). Interrater agreement for key quality indicators (for example concealment of allocation) was calculated using the kappa statistic (Cohen 1960). In cases of disagreement, the rest of the group would have been consulted and a judgement would have been made based on consensus.

\section{Measures of treatment effect}

\section{Dichotomous data}

Dichotomous outcomes (for example diabetic retinopathy yes/no) were expressed as odds ratios (OR) or relative risks (RR) with 95\% confidence intervals $(\mathrm{Cl})$.

\section{Continuous data}

Continuous outcomes (for example metabolic control as measured by glycosylated haemoglobin $\mathrm{Alc}(\mathrm{HbAlc})$ ) were expressed, if possible, as mean differences with $95 \% \mathrm{Cl}$.

\section{Time-to-event data}

Time-to-event outcomes (for example time until kidney failure) were expressed as hazard ratios (HR) with $95 \% \mathrm{Cl}$.

\section{Unit of analysis issues}

We planned to take into account the level at which randomisation occurred, such as cross-over trials, cluster-randomised trials and multiple observations for the same outcome.

\section{Dealing with missing data}

Relevant missing data were sought from authors. Evaluation of important numerical data such as screened, eligible and randomised patients as well as intention-to-treat and per-protocol population were carefully performed. Drop-outs, missing to followup and withdrawn study participants were investigated. Issues of last-observation-carried-forward (LOCF) were critically appraised and compared to specification of primary outcome parameters and power calculation.

\section{Assessment of heterogeneity}

Heterogeneity was investigated using inspection of forest plots (Lewis 2001) and $\mathrm{Chi}^{2}$ test at a significance level of $\alpha=0.1$. 
Heterogeneity was quantified using the $\mathrm{I}^{2}$ statistic (which describes the proportion of variability that is due to heterogeneity rather than sampling error), where $1^{2}$ values of $50 \%$ and more indicate a substantial level of heterogeneity (Higgins 2002; Higgins 2003; Higgins 2005).

\section{Assessment of reporting biases}

Funnel plots were planned to be used to assess potential existence of small study bias. There are a number of explanations for the asymmetry of a funnel plot, including true heterogeneity of effect with respect to study size, poor methodological design of small studies and publication bias (Sterne 2001). Thus, this exploratory data instrument may be misleading and we did not plan to place undue emphasis on this tool (Lau 2006).

\section{Data synthesis}

Data were summarised statistically, where they were sufficiently similar and of sufficient quality. Review Manager 5.0 was used to collect, record and analyse data.

\section{Subgroup analysis and investigation of heterogeneity}

Subgroup analysis would have been performed if one of the primary outcome parameters had demonstrated statistically significant differences between treatment groups. The following subgroup analyses were planned:

- age;

- sex;

- ethnicity of participants.

\section{Sensitivity analysis}

Sensitivity analysis was performed to include one large study in which the standard deviation of the outcome measures was not available but was estimated using the interquartile range.

In the original review it was anticipated that we would perform sensitivity analyses in order to explore the influence of the following factors on effect size:

- repeating the analysis excluding unpublished studies;

- repeating the analysis taking account risk of bias, as specified above;

- repeating the analysis excluding any very long or large studies to establish how much they dominate the results;

- repeating the analysis excluding studies using the following filters: language of publication, source of funding (industry versus other), country;

- repeating the analysis using different diagnostic criteria of LADA.

The robustness of the results would also be tested by repeating the analysis using different measures of effects size (risk difference, odds ratio etc.) and different statistical models (fixed-effect model and random-effects model). However, there were few studies identified and therefore, these analyses could not be performed.

\section{RES U L T S}

\section{Description of studies}

\section{Results of the search}

Electronic searches (including MEDLINE, EMBASE, Web of Knowledge) and hand searches undertaken in December 2010, identified 13,306 citations, of which 4217 were duplicates. Duplicates were identified by collating all citations into one Endnote database. A duplicate search was then carried out and each citation checked to ensure that it was a duplicate and not an additional paper. The titles and abstracts of 9089 citations were independently reviewed by SB and HD and 61 citations either met the inclusions criteria or required sight of the full paper before a decision could be made. Three citations were also retrieved as they were reviews which could have contained relevant articles in the reference list. No abstracts required translation. Four papers required translation, two were written in Chinese (Xu 2008; Zhou 2005), one in German (Schories 2004) and one in Japanese (Matsumoto 2005). Two abstracts from conference proceedings were identified. We wrote to authors and had confirmation that these abstracts had not been written as papers yet. For a PRISMA (preferred reporting items for systematic reviews and metaanalyses) flow-chart of study selection (Liberati 2009) please see Figure 1.

Agreement was calculated between the authors with a kappa statistic of 0.91 (difference of opinion on 2/56 publications), foreign language articles were read only by one author. The two manuscripts where there were differences of opinion were resolved by discussion between the authors.

\section{Included studies}

A total of fifteen publications, reporting ten studies, met the inclusion criteria. One trial was carried out in Japan giving pilot data, four year follow-up and five year follow-up (Kobayashi 1996, Kobayashi 2002; Maruyama 2003, Maruyama 2008), four studies have been carried out in China (Li 2009; Xu 2008; Zhu 2004; Zhou 2005) and three year follow-up of one of these trials is now available (Yang 2009), three studies were conducted in Sweden (Agardh 2005; Agardh 2009; L-Hallin 1999 and Thunander 2010), one in Cuba (Cabrera-Rode 2002) and one in the UK (Davis 2005).

\section{Study design}

All publications included in the review were randomised controlled trials. There were two publications reporting short term followup (0 to 6 months: L-Hallin 1999 Xu 2008), three publications on medium term follow-up (7 to 12 months: Cabrera-Rode 2002; Li 2009; Zhu 2004) and ten publications on long-term follow-up (more than 12 months: Agardh 2005; Agardh 2009; Davis 2005; Kobayashi 1996; Kobayashi 2002; Maruyama 2003; Maruyama 2008; Thunander 2010; Yang 2009; Zhou 2005).

\section{Participants}

A total of 1019 participants (1060 randomised) were included in the fifteen publications (ten studies). The smallest study included 14 participants and the largest 488 participants. All trials recruited adults with a diagnosis of type 2 diabetes with the presence of antibodies. However, the selection criteria to define latent autoimmune diabetes in adults (LADA) varied with each study (Appendix 2). Two papers were included as they reported findings 
for type 2 antibody positive patients (Davis 2005; L-Hallin 1999) . However, these patients were not labelled as LADA within these trials and these were not intervention trials specifically for LADA. The selection criteria for these trials were: Type 2 diabetes patients who failed treatment with sulphonylureas alone (L-Hallin 1999), and people with type 2 diabetes aged 25 to 65 years (Davis 2005). In both these studies an extract of results of those positive was provided by the authors. No trials reported ethnicity, therefore we have to assume that the patients recruited were mainly of the ethnicity of the country conducting the trial. There were no selection criteria for disease duration of the participants at entry for the majority of studies. For example, L-Hallin 1999 had a mean disease duration of 9.9 years in one arm of the study, Cabrera-Rode 2002 had one participant with a disease duration of 7 years and seven participants with a duration less than one year. The duration was selected as newly diagnosed for one study (Davis 2005) and diagnosed within five years for five studies (Kobayashi 1996; Li 2009; Maruyama 2008; Yang 2009; Zhou 2005) and in four trials the average disease duration was not described (Agardh 2005; Agardh 2009; Kobayashi 2002; Xu 2008; Zhu 2004).

\section{Interventions}

All trials examined interventions for LADA or antibody positive type 2 diabetes. One trial examined GAD65 immunomodulation at three different doses compared to placebo (Agardh 2005 \& Agardh 2009), one examined insulin compared to insulin and sulphonylurea (Cabrera-Rode 2002), one study (pilot, main trial and follow-up in Japan) examined insulin compared to sulphonylurea alone (Kobayashi 1996 \& Kobayashi 2002; Maruyama 2003; Maruyama 2008), one examined insulin and sulphonylurea given together with one group having withdrawal of sulphonylurea after four months (L-Hallin 1999), one examined insulin compared to insulin and rosiglitazone (Zhou 2005 \& Yang 2009), one examined the protective effects of vitamin D in LADA (Li 2009) and one examined insulin compared to conventional treatment (diet+/- OHA, metformin and/ or sulphonylurea) (Thunander 2010). In addition, Xu 2008 examined Chinese medicine, Tangyikang, combined with insulin, compared to insulin alone and finally there were two three-armed trials (Zhu 2004 examined insulin compared to insulin and Chinese medicine together compared to sulphonylurea alone and Davis 2005 examined insulin compared to sulphonylurea compared to diet treatment).

\section{Outcome measures}

None of the trials reported on the development of complications such as retinopathy, neuropathy or cardiovascular disease. However, seven studies reported on the development of adverse events (Agardh 2005 \& Agardh 2009; Kobayashi 1996 \& Maruyama 2003 \& Maruyama 2008; L-Hallin 1999; Li 2009; Thunander 2010; Yang 2009 Zhou 2005). Fourteen papers reported measures of metabolic control, eleven reported glycosylated haemoglobin A1c ( $\mathrm{HbA1C}$ ) and nine reported fasting glucose levels. The only study not reporting metabolic control was Maruyama 2003. No trials reported health service utilisation or costs or health-related quality of life. No studies reported on hypertension, hyperlipidaemia, lipid profile, microalbuminuria or mortality rates.

\section{Excluded studies}

Forty three articles were excluded after reading the full text. Reasons for exclusion were: not LADA (classical type 1 with insulin dependence at diagnosis or type 2 diabetes without antibodies), or no intervention given, or not a randomised or control trial (please see Characteristics of excluded studies). One paper was excluded (Kobayashi 2002) as it was thought to be a summary publication of two other included papers (Kobayashi 1996; Maruyama 2003). Therefore, it did not contribute any new data. One was excluded as we could not separate the antibody positive (LADA) patients from the antibody negative (type 2 diabetes) patients (E-Longmire 2004). Another which examined LADA and the usefulness of early insulin therapy was excluded as it was not a randomised or controlled study (Rosario 2007).

\section{Risk of bias in included studies}

Two of the studies were pilot studies and therefore did not present power calculations (Agardh 2005; Kobayashi 1996). Other studies which were not presented as pilot studies also did not present power calculations (Cabrera-Rode 2002; Davis 2005; Li 2009; Maruyama 2003; Thunander 2010; Xu 2008; Zhu 2004; Zhou 2005). L-Hallin 1999 did present a power calculation but this was for the whole group and not just for the antibody positive patients.

\section{Allocation}

Of the ten randomised controlled trials, Thunander 2010 reported that strict randomisation was not performed, since some patients refused randomisation to possible insulin treatment and they were referred to the control group. Maruyama 2008 reported a centralized, masked-draw system and Xu 2008 reported using a random number table. However, none of the other studies described the method of randomisation.

\section{Blinding}

Blinding to treatment was not possible in the majority of studies, with the exception of Agardh 2005, and Agardh 2009 which was a double-blind trial. Details of blinding the outcome assessors was not described in any of the studies.

\section{Incomplete outcome data}

There were no losses to follow-up in four RCT's (Cabrera-Rode 2002; Kobayashi 1996; Li 2009, Zhu 2004). In one RCT it was unclear how many patients were randomised in the beginning so it was difficult to tell if there were losses to follow-up (Matsumoto 2005). The text in Maruyama 2003 states that 56 patients were analysed, but the baseline characteristics are only given for 54 patients. Davis 2005 did not provide information on numbers lost to follow-up given in the paper or in communication with the authors. In the remaining five studies loss to follow-up was reported: Agardh 2009 40/47 patients completed the five year study; Zhou 2005, there were no losses at six months, six (26\%) losses at 12 months and nine (39\%) at 18 months; Yang 2009 (the follow-up study to Zhou 2005) with additional study groups (SUR group and RSG group) reported no losses to follow-up; L-Hallin 1999 there was one out of $15(7 \%)$ lost at four months and another one (13\%) lost at eight months; Thunander 2010 there was $90 \%$ follow-up (18/20 (insulin group) and $15 / 17$ (conventional group) to 36 months.

Maruyama 2008 and Thunander 2010 reported to use intentionto-treat analysis. Of the remaining eight randomised controlled trials, none specifically stated that intention to treat analysis (ITT) was performed, however communication with the authors of Davis 2005 confirmed that the results that they gave us were based on ITT. Four RCTs (Cabrera-Rode 2002; Kobayashi 1996; Li 2009; Zhu 2004) did not have any losses to follow-up. L-Hallin 1999 provided 
their raw data so we could perform an intention-to-treat analysis ourselves. Zhou 2005 did not perform intention-to-treat analysis, there were loses to follow-up and only those remaining in the end were analysed. Maruyama 2003 did not report to use ITT and it was unclear how may patients were included in the beginning.

\section{Selective reporting}

The majority of studies reported $\mathrm{HbAlc}$ with the exception of Cabrera-Rode 2002 and Li 2009. A measure of C-peptide was measured in the majority of studies with the exception of Davis 2005. However, in all studies the methods to estimate the C-peptide differed and therefore could not be compared.

\section{Other potential sources of bias}

Studies which had funding from a pharmaceutical company which could directly gain from the findings included Agardh 2005 \& Agardh 2009, Davis 2005 and L-Hallin 1999. Specifically, Agardh 2005 and Agardh 2009 was supported by Diamyd Therapeutics, Davis 2005 was funded by a range of companies including Novo-Nordisk, Bayer, Bristol Myers Squibb and Lilly, L-Hallin 1999 was supported by grants from Hoechst AG (Sanofi-Aventis). Maruyama 2008 and Zhou 2005 did not report on who gave funding and sponsorship.

\section{Effects of interventions}

See: Summary of findings for the main comparison

For details see Appendix 3.

\section{Primary outcomes}

\section{Development of diabetic complications}

No study reported on development of diabetic complications.

\section{Metabolic control}

\section{Glycosylated haemoglobin A1c (HbA1c) and fasting blood glucose (FBG)}

\section{Short term (0 to 6 months)}

L-Hallin 1999 was an observational study with insulin and sulphonylureas (SU) given together (15 patients), then patients were randomised to insulin only or insulin with SU. The following results were provided by authors in personal communication: In this study SU was withdrawn at four months (three patients randomised but one lost due to hypoglycaemia) and in the remaining patients ( $n=12$, with one lost to follow-up) insulin and SU were continued. An observational follow-up of the first four months showed that glutamic acid decarboxylase (GAD) positive patients $(n=15)$ had a change of HbAlc of $9.4 \%$ (SD 1.5) to $7.2 \%$ (SD 1.5) or an improvement of $-2.3 \%$ (95\% confidence interval (CI) $-1.2 \%$ to $-3.4 \%$ ) using a combination of insulin and SU together. After randomisation the insulin only group had an $\mathrm{HbAlc}$ of $8.2 \%$ (SD 1.6, $\mathrm{n}=2$ ) and the insulin and SU group had an HbA1C of $7.8 \%$ ( $S D 1.1 ; n=12, P=0.6$; mean difference $-0.4 \%(95 \% \mathrm{Cl}-2.4$ to 1.6$)$ ). The FBG at baseline was $12.6 \mathrm{mmol} / \mathrm{L}$ (SD 3.3) and at the end of the first four months was $8.3 \mathrm{mmol} / \mathrm{L}$ (SD 1.6), after randomisation the insulin only group was $10.7 \mathrm{mmol} / \mathrm{L}$ (SD 5.9) and the insulin plus SU group was $11.2 \mathrm{mmol} / \mathrm{L}$ (SD 2.5) (mean difference $0.45 \mathrm{mmol} / \mathrm{L}$ ( $95 \%$ $\mathrm{Cl}-4.6$ to $5.5, \mathrm{P}=0.8$ ). Therefore, there was no significant difference in the two groups examining 14 patients (two in one group and 12 in the other).
Agardh 2005 was an RCT of GAD65 which showed improved HbA1c when compared to those treated with placebo at six months ( $\mathrm{n}$ = 49). There were increased HbAlc levels in the placebo $(+0.6 \%$ (SD 0.3)) and $4 \mu \mathrm{g}(+0.3 \%$ (SD 0.2)) dose group but not in the dose groups receiving higher dose levels of GAD65 subcutaneous injections (-0.1\% (SD 0.2) and +0.1 (SD 0.3)) in the $100 \mu \mathrm{g}$ and $500 \mu \mathrm{g}$, respectively $(P=0.029)$. In terms of FBG the placebo and low dose $(4 \mu \mathrm{g})$ both showed an increase in FPG at 24 weeks $(+1.2 \mathrm{mmol} / \mathrm{L}$ (SD 0.7) and +1.3 (SD 1.4), respectively), but the higher dose groups showed a decrease $(P=0.038)(-0.7(S D 1.1)$ at $20 \mu \mathrm{g},-0.3(S D 0.5)$ at $100 \mu \mathrm{g}$ and -0.9 (SD 1.2) at $500 \mu \mathrm{g}$. Therefore, patients receiving the higher dose $(100 \mu \mathrm{g}$ and $500 \mu \mathrm{g})$ showed improved metabolic control.

Xu 2008 was an RCT examining the effect and mechanism of Tangyikang (TYK) a herb decoction for improving pancreatic islet $B$ cell function in patients with LADA. 74 participants were followed up for three months. The insulin and TYK group $(n=37)$ showed no difference in $\mathrm{HbAlC}(7.17 \pm 0.59)$ compared with insulin alone group $(7.11 \pm 0.51, n=37)$. Similarly, in terms of FBG there was no difference in either group.

\section{Medium term ( 7 to 12 months)}

Zhu 2004 was a three armed RCT examining insulin alone $(n=33)$, insulin and Chinese medicine $(n=31)$ and SU alone $(n=20)$. Baseline HbA1c measures were 8.9\% (SD 2.4), 9.0 (SD 2.6) and 8.7 (SD 1.9) for insulin alone, insulin and Chinese medicine and SU, respectively. $\mathrm{HbA1C}$ at 12 months was 6.6 (SD 2.1), 6.1 (SD 1.8) and 7.3 (SD 1.6). Comparing insulin alone with $\mathrm{SU}$ alone there was no significant difference in the groups (mean difference of $-0.7 \%(95 \% \mathrm{Cl}-0.3$ to 1.7)); insulin and Chinese medicine compared to SU alone show a significant difference at 12 months (mean difference $1.2 \%(95 \% \mathrm{Cl}$ 0.25 to 2.1 ) and there was no significant difference between insulin alone and insulin with Chinese medicine (mean difference 0.5\% ( $95 \% \mathrm{Cl}-0.5$ to 1.5$)$. The mean baseline FBG was 9.7 (SD 3.2) in the insulin only group, 9.8 (SD 4.5) in the insulin and Chinese medicine group and 9.7 (SD 2.8) in the SU group. At 12 months there was no significant difference in the insulin compared to the SU group. Results were $6.9 \mathrm{mmol} / \mathrm{L}$ (SD 2.7) in the insulin only group and 7.6 $\mathrm{mmol} / \mathrm{L}$ (SD 2.4) for the SU group, mean difference 0.7 (95\% Cl -2.1 to 0.7 ), but there was a significant difference between insulin with Chinese medicine and the SU group. Results were $6.2 \mathrm{mmol} / \mathrm{L}$ (SD $2.5)$ in the insulin and Chinese medicine group compared to 7.6 $\mathrm{mmol} / \mathrm{L}$ (SD 2.4) in the SU group, mean difference 1.4 (95\% Cl 0.03 to 2.8). There was no difference between insulin alone and insulin with Chinese medicine groups (mean difference 0.7 (95\% Cl: -0.6 to 2.0). Therefore in summary, insulin and Chinese medicine showed improved metabolic control compared to SU.

Zhou 2005 was an RCT of insulin alone $(n=12)$ compared to insulin with rosiglitazone $(n=11)$. Baseline HbAlc was a median of $8.1 \%$ (range 5.3 to 16.1) and 7.2 (range 4.7 to 13.0), respectively. Results of 17 patients (nine in insulin only group and eight in the insulin plus rosiglitazone group) at 12 months showed no significant difference from baseline in the insulin group (median HbA1c 6.8\% (range 5.8 to 11.5), but a significant difference from baseline in the insulin and glitazone group (median HbA1c 5.6\% (range 5.3 to 9.2), $\mathrm{P}<0.05$ ), but no significant difference between groups. FBG was not recorded within this study.

Cabrera-Rode 2002 was an RCT of insulin and glibenclamide $(\mathrm{n}=$ 6 ) compared to insulin alone $(n=8)$. HbAlc was not recorded in 
this study. Baseline FBG was $10 \mathrm{mmol} / \mathrm{L}$ (SD 3.0) in the insulin plus glibenclamide group and $7.8 \mathrm{mmol} / \mathrm{L}$ (SD 2.9) in the insulin only group (no significantly difference $(95 \% \mathrm{Cl}-0.9$ to 5.3$)$. At 12 months the insulin plus glibenclamide group showed a FBG of $11.5 \mathrm{mmol} /$ $L$ (SD 5.5) and the insulin only group a FBG of $4.6 \mathrm{mmol} / \mathrm{L}$ (SD 2.8) (mean difference $6.9(95 \% \mathrm{Cl} 2.0$ to 11.7$), \mathrm{P}=0.0023)$.

Thunander 2010 was a block randomised trial with incomplete randomisation (i.e. patients randomised to insulin who refused insulin were analysed within the tablet arm instead of within the insulin arm as with intention to treat analysis). This study examined insulin ( $\mathrm{n}=20$ ) compared to OHA (metformin and/or SU, $\mathrm{n}=17)$ and baseline $\mathrm{HbA1c}$ was 7.3 (SD 1.3) in the insulin group compared to 7.0 (SD 1.3) in the tablet arm, and at 12 months 7.1 (SD 1.0) and 6.7 (SD 1.4) respectively. Giving no significant difference between insulin and conventional treatment in terms of change from baseline.

\section{Long-term (more than 12 months)}

Zhou 2005 examined insulin alone $(n=12)$ compared to insulin with rosiglitazone $(n=11)$. Baseline HbA1c is given above. Results of 14 patients (seven in each group) at 18 months showed no significant differences from baseline in either group and no significant differences between groups (median $7.7 \%$ (range 6.3 to 9.8 ) in the insulin only group and median $6.3 \%$ (range 5.0 to 9.3 ) in the insulin plus rosiglitazone group). FBG was not recorded in this study.

Yang 2009 appears to be a three year follow-up of Zhou's study with addition comparison groups. This study compared four groups, insulin alone $(n=12)$, insulin with rosiglitazone $(n=12)$, SU $(n=$ 14) and RSG $(n=15)$ for the beneficial effects on beta cell function. 54 LADA patients were assigned to either the rosiglitazone group (GADA $<175$ WHO Units $/ \mathrm{mL}$ and FCP $>0.3 \mathrm{nmol} / \mathrm{L}$ ) or a early insulin group (GADA $\geq 175$ WHO Units $/ \mathrm{mL}$ and $\mathrm{FCP} \leq 0.03 \mathrm{nmol} / \mathrm{L}$ ). Then, those patients were randomly assigned to receive sulphonylureas (SU group, $n=14$ ) or rosiglitazone (RSG group, $n=15$ ) therapy, or to receive insulin alone (INS group, $\mathrm{n}=12$ ) or rosiglitazone plus insulin (INS + RSG group, $n=12$ ). In the insulin alone group baseline HbA1c was $7.50 \pm 3.20$ and at 36 months $8.73 \pm 2.80$. In the insulin with RSG the baseline $\mathrm{HbA} 1 \mathrm{c}$ was $8.11 \pm 2.74$ and at 36 months $8.25 \pm 1.91$. In the SU group at baseline HbA1c was $7.78 \pm 2.16$ and at 36 months was $8.23 \pm 2.54$, and in the RSG alone group baseline $\mathrm{HbA1c}$ was 8.31 and at 36 months $6.80 \pm 1.08$. Thus, in those patients with low GADA and $\mathrm{FCP}>0.3 \mathrm{nmol} / \mathrm{L}$ there was no significant difference in $\mathrm{HbAlc}$ change from baseline for those treated with SU compared to RSG (mean difference: -1.92 (95\% Cl: -4.2 to 0.33$)$ ). Simularly, in those patients with high GADA and $\mathrm{FCP}<0.3 \mathrm{nmol} / \mathrm{L}$ treated with insulin or insulin and RSG there was no significant difference in terms of HbA1c. FBG was not recorded in this study.

Kobayashi 1996 was a pilot RCT examining insulin alone $(n=5)$ compared to SU alone $(n=5)$. Baseline $\mathrm{HbAlc}$ was $7.8 \%$ (SD 0.4) and $8.5 \%$ (SD 0.6) in the insulin compared to SU groups, respectively. Results at 30 months of follow-up showed a significant difference in the two groups with an end of study HbAlc of $7.3 \%$ (SD 0.9 ) and $11.2 \%$ (SD 1.3), respectively and a mean difference of $3.9 \%(95 \% \mathrm{Cl}$ 2.5 to 5.2), $P<0.05$ ). Baseline FBG was $9.6 \mathrm{mmol} / \mathrm{L}$ (SD 1.4) in the insulin group and $9.6 \mathrm{mmol} / \mathrm{L}$ (SD 1.9) in the SU group. At 30 months this had changed to $7.3 \mathrm{mmol} / \mathrm{L}$ (SD 1.7) and $10.1 \mathrm{mmol} / \mathrm{L}$ (SD 1.4), respectively. This was a significant difference between the groups with a mean difference of $2.8 \%(95 \% \mathrm{Cl} 0.9$ to 4.7$), \mathrm{P}=0.02)$. Two of the five patients in the SU group were being treated with insulin at the end of the study. Therefore, comparison of insulin versus SU was a comparison of $100 \%$ on insulin compared to $40 \%$ on insulin at 30 months.

Davis 2005 was a three armed study examining conventional treatment $(n=100)$ compared to insulin $(n=95)$ compared to SU $(n=140)$ in patients with a fasting blood glucose measure of 6.0 to $14.9 \mathrm{mmol} / \mathrm{L}$ at baseline and examining insulin $(n=65)$ compared to $\mathrm{SU}(\mathrm{n}=88)$ in patients with a FBG of more than $15 \mathrm{mmol} / \mathrm{L}$. Results (provided by authors in personal communication) showed at baseline an HbA1c of $6.7 \%$ (SD unknown), $7.1 \%$ and $7.0 \%$ for conventional, insulin and SU groups, respectively. At four years the $\mathrm{HbA1c}$ was $8.4 \%$ (conventional treatment), $7.5 \%$ (insulin) and $7.1 \%$ (SU). At 10 years results were $9.6 \%$ (conventional treatment), $8.2 \%$ (insulin) and $8.7 \%$ (SU) in the FBG group of 6.0 to $14.9 \mathrm{mmol} / \mathrm{L}$. In the FBG group of more than $15 \mathrm{mmol} / \mathrm{L}$ the baseline $\mathrm{HbA1c}$ was $10.5 \%$ (insulin) and $11.2 \%$ (SU), at four years this was $8.3 \%$ (insulin) and $9.1 \%(\mathrm{SU})$ and at 10 years $8.8 \%$ (insulin) and $8.8 \%$ (SU). However, Davis 2005 reported $60 \%$ of the patients with a FBG greater than $15 \mathrm{mmol} / \mathrm{L}$ became insulin requiring within two years of diagnosis when allocated to SU treatment. Therefore, measures after two years are comparing a $100 \%$ insulin group with a $60 \%$ to $80 \%$ insulin group. In the FBG 6.0 to $14.9 \mathrm{mmol} / \mathrm{L}$ group approximately $30 \%$ of SU patients were treated with insulin at four years. FBG was not recorded in this study. In addition, this was an intention to treat analysis and losses to follow-up in the whole study (antibody positive and negative patients together) accounted to $48 \%$.

Maruyama 2008 was a 5 year follow-up RCT examined insulin alone $(n=30)$ compared to SU alone $(n=30)$. The HbAlc levels at the end of the follow-up (insulin group, $7.2 \pm 1.6 \%$; SU group, $7.7 \pm$ $1.4 \%)$ did not significantly differ from those at baseline. The $2-\mathrm{h}$ BG levels were significantly increased at the completion of study in both groups (insulin group; $352 \pm 107 \mathrm{mg} / \mathrm{dl}(19.5 \pm 5.9 \mathrm{~mol} /$ litre), $\mathrm{P}$ $=0.004$ vs baseline; SU group: $388 \pm 116 \mathrm{mg} / \mathrm{dl}(21.5 \pm 6.4 \mathrm{mmol} / \mathrm{L})$, $\mathrm{P}<0.001$ vs baseline). The FBG value at 60 months in the SU group $[184 \pm 65 \mathrm{mg} / \mathrm{dl}(10.2 \pm 3.6 \mathrm{mmol} / \mathrm{L})]$ was significantly increased compared with baseline $(P<0.001)$, whereas the insulin group [153 $\pm 59 \mathrm{mg} / \mathrm{dl}(8.5 \pm 3.3 \mathrm{mmol} / \mathrm{L})]$ was not. The FBG value at 60 months in the insulin group was lower that in the SU group $(P=0.04)$.

Agardh 2009 was a 5 year follow-up of Agardh 2005 a RCT of GAD65 in 47 people. $\mathrm{FBG}$ and $\mathrm{HbA1c}$ was reported on in 4 months followup as outlined earlier. FBG was only collected in patients without insulin treatment at baseline, 2,6,9, and 12 months and thereafter every half year up to 5 years. HbA1c was similarly measured from 3 months. The results for FBG and HbA1c were not reported in Agardh 2009.

Thunander 2010 was a 3 year follow-up study examining insulin alone $(n=20)$ compared to OHA (metformin and/or SU, $n=17)$ and baseline HbA1c was 7.3 (SD 1.3) in the insulin group compared to 7.0 (SD 1.3) in the tablet arm, and at 36 months 7.2 (SD 0.7 ) and 7.5 (SD 1.5) respectively. Giving no significant difference between insulin and conventional treatment in terms of change from baseline. FBG was not reported.

Meta-analysis: A meta-analysis examining insulin alone compared to tablet treatment ( $\mathrm{SU}+/$ - metformin) was performed combining: Kobayashi 1996 (30 months follow-up, tablet SU), Maruyama 2008 (60 months follow-up, tablet SU), Thunander 2010 (36 months follow-up, tablet metformin+/-SU) and the insulin arm and SU arm in Zhu 2004 (12 months follow-up). Yang 2009 was excluded as 
the SU arm and insulin only arm were not comparable as the selection criteria stratified the patients based on GADA and FCP level. Davis 2005 was excluded from the initial analysis because the standard deviations of the $\mathrm{HbAlc}$ values were not available and patients were stratified based on FBG level. This meta-analysis shows the combined difference in $\mathrm{HbAlc}$ change from baseline to study endpoint of $-1.3 \%(95 \% \mathrm{Cl}-2.4$ to -0.1$) ; \mathrm{P}=0.03,160$ participants, 4 trials, Figure 2 . These are the first results of a random-effect meta-analysis and represent the average from the distribution of treatment effects across studies. Heterogeneity is caused by Kobayashi 1996 which has the smallest sample size and so more studies will be needed to give more certainty to the intervention effect. Davis 2005 was excluded from this analysis as we did not have the standard deviations for the HbAlc. However, the interquartile range was published as 6.2 to 9.5. This can be used to estimate a standard deviation $(3.3 / 1.3489=2.4)$. This estimated standard deviation (which assumes a normal distribution and assumes that the groups stratified on FBG level have the same standard deviation - both assumptions suspected to be false) was used to examine if the addition of the Davies study changes the findings. Taking those patients stratified with high FBG did not change the findings of the meta-analysis (Figure 3, Analysis 2.1). In addition, the considerable heterogeneity due to Kobayashi 1996 would mean there is still uncertainty in the effect of insulin compared to SU (+/- metformin).

\section{Figure 2. Forest plot of comparison: Insulin compared to tablet, Outcome: Average mean difference in HbA1c from} baseline to study endpoint.

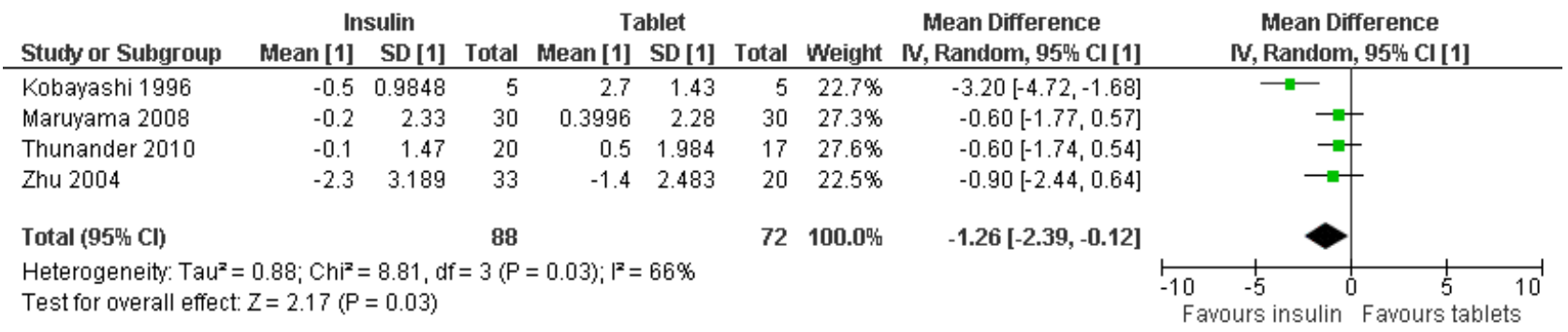

Figure 3. Forest plot of comparison: 2 Sensitivity analysis, outcome: $2.1 \mathrm{HbA1C}$ at final point.

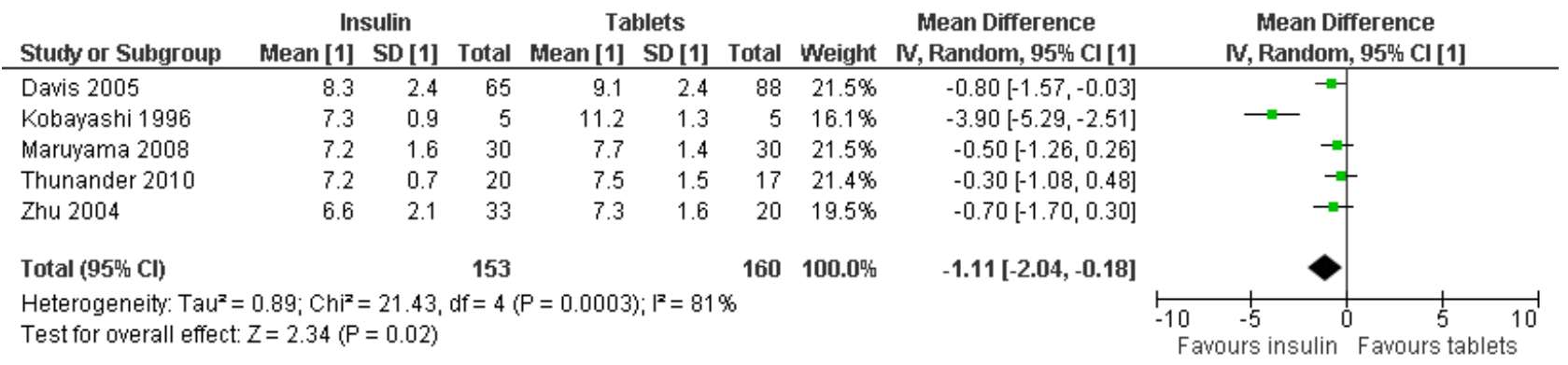

In summary, data suggest that the study examining withdrawal of SU compared to insulin and SU was underpowered for antibody positive patients (L-Hallin 1999). An early pilot study using glutamic acid decarboxylase (GAD) 65 suggests it could improve metabolic control (Agardh 2005). In a Chinese population, Chinese medicine and insulin improved metabolic control when compared to SU treatment. In a Chinese population insulin with rosiglitazone did not improve metabolic control when compared to insulin alone at 12 and 18 months (Zhou 2005). However, metabolic control is improved with rosiglitazone alone when compared to insulin alone at 36 months follow-up (Yang 2009). In a Cuban population insulin improved metabolic control at 12 months when compared to SU plus insulin (Cabrera-Rode 2002). A meta-analysis of insulin alone compared to $\mathrm{SU}+/$ - metformin for metabolic control $(\mathrm{HbAlc})$ suggested the patients in the insulin arm showed improved metabolic control in comparison to SU. The average improvement was a HbAlc of $1.3 \%$ less in the insulin arm in comparison to SU when baseline levels are taken into account. However, heterogeneity was considerable.

\section{Progression to insulin}

No short term or medium term studies discussed progression to insulin dependence. However, in the insulin plus SU trial (CabreraRode 2002) there were no significant differences between the groups in terms of units of insulin per day at 12 months ((33 U (SD 23 ) in the insulin plus SU and $31 \mathrm{U}$ (SD 29) in the insulin only group).

\section{Long-term (more than 12 months)}

Zhou 2005 reported that the daily insulin doses were less in the insulin plus rosiglitazone group compared to the insulin alone group (15 $\mathrm{U}$ per day compared to $26 \mathrm{U}$ per day $(\mathrm{P}=0.032)$ ) after 18 months of follow-up, suggesting that more natural insulin may be available in the insulin plus rosiglitazone group.

Yang 2009 a 36 months follow-up of Zhou 2005 reported that the daily insulin doses were less in the insulin plus rosiglitazone group compared to the insulin alone group $(0.33 \pm 0.22(\mathrm{U} / \mathrm{kg} \mathrm{d})$ per day compared to $0.42 \pm 0.25(\mathrm{U} / \mathrm{kg} \mathrm{d}))$ after 36 months follow-up. 
Maruyama 2003 defined an insulin dependent state as an integrated C-peptide response below $4 \mathrm{ng} / \mathrm{ml}$. Using this definition $30 \%$ of the SU group (9/30) progressed to insulin dependence by 48 months (four years) of follow-up and $8 \%(2 / 24)$ of the insulin treated group progressed to this stage $(P=0.087)$. In those patients who had a preserved $\mathrm{C}$-peptide response at baseline (that is had high levels of their own insulin producing beta cells), the proportion of the SU group progressing to insulin dependence was $7 / 28(25 \%)$ compared to $0 / 21(0 \%)$ in the insulin treated group $(P=0.015)$. In patients with high GAD titre's $9 / 14(64.3 \%)$ of the SU group and $2 / 16(12.5 \%)$ of the insulin group $(P=0.007)$ progressed to insulin dependence.

Davis 2005 presented graphs of the proportion of patients who became insulin requiring according to clinical criteria. In these graphs, for the patients who had a FBG at baseline of 6.0 to 14.9 $\mathrm{mmol} / \mathrm{L}$, the percentage of patients who required insulin using SU at four years was $22 \%$ compared to approximately $5 \%$ in the conventional group $(P<0.001)$. This suggests that the use of SU may promote insulin dependence when compared to conventional treatment. In the FPG >15 mmol/L group approximately 55\% were insulin dependent at 2 years.

Maruyama 2008 a 5 year follow-up of Maruyama 2003 showed 43\% of patients in the SU group (13/30) and $10 \%(3 / 30)$ in the insulin group progressed to an insulin-dependent state.

Agardh 2009 reported 48\% (19/40) started insulin within 5 years of baseline. Of these $53 \%$ (10) had low fasting C-peptide at baseline.

Thunander 20100 reported that 30\% (5/17) of those treated with tablets started insulin due to clinical necessity within 30 months (2 at 6 months, 1 within 12 months, 2 within 24 months and 1 at 30 months).

\section{Adverse events}

Adverse events were only reported in five studies. Kobayashi 1996, L-Hallin 1999 and Thunander 2010 reported no severe hypoglycaemia events. Li 2009 reported no severe hypercalciuria, hypercalcaemia, hypoglycaemic attacks, liver dysfunction or other side effects observed in either group. Maruyama 2003 and Maruyama 2008 reported no adverse reactions and severe hypoglycaemia were not documented during the study. Zhou 2005 reported no severe hypoglycaemic attacks or liver dysfunction. However, in Agardh 2005 there were three possibly related adverse events (leukocytosis and mild inflammation at the injection site in the active group and vitiligo in the placebo group) and a total of 51 adverse events were reported in total in the trial. The five year follow-up study Agardh 2009 reported 14 serious adverse events (SAE) in ten patients during follow-up. Four patients were in the placebo group studies which did not report on adverse events (Cabrera-Rode 2002; Zhu 2004). There were no reported mortalities in any of the studies.

\section{Secondary outcomes}

\section{C-peptide}

\section{Short term (0 to 6 months)}

L-Hallin 1999 followed 15 patients treated with SU plus insulin for four months, two were then randomised to insulin alone and 12 to SU plus insulin (two lost to follow-up). The baseline fasting Cpeptide (FCP) was $0.64 \mathrm{nmol} / \mathrm{L}$ (SD 0.29) and at four months, this had gone down to 0.52 (SD 3.2). After randomisation the FCP of the insulin only group $(\mathrm{n}=2)$ was $0.72 \mathrm{nmol} / \mathrm{L}(\mathrm{SD} 0.12)$ and of the insulin and SU group $0.43 \mathrm{nmol} / \mathrm{L}(\mathrm{SD} 0.2)$, a mean difference of $0.29 \mathrm{nmol} /$ $\mathrm{L}(95 \mathrm{Cl}-0.12$ to $0.71, \mathrm{P}=0.15)$.

Agardh 2005 examined placebo and a low dose of GAD65 (4 $\mu \mathrm{g})$ compared to higher doses of GAD65 (20 $\mu \mathrm{g}$ to $500 \mu \mathrm{g})$ over six months. At baseline the FCP was $0.69 \mathrm{nmol} / \mathrm{L}$ (SD unknown, $\mathrm{n}=$ 27 ) in the placebo or low dose group and was $0.62 \mathrm{nmol} / \mathrm{L}$ (SD unknown, $n=27$ ) in the higher doses groups. At six months the $C$ peptide had improved to $0.76 \mathrm{nmol} / \mathrm{L}$ in the higher doses groups and had decreased to $0.55 \mathrm{nmol} / \mathrm{L}$ in the low dose or placebo group. There was a significant difference in FCP levels at 24 weeks in the $20 \mu \mathrm{g}$ dose group when compared to placebo at the $5 \%$ significance level.

Xu 2008 followed 74 patients treated with TYK (herbal decoction) with insulin and insulin alone for 3 months. Results showed significant difference in C-peptide levels between the TYK and insulin group $(0.258 \pm 0.106)$ compared with the insulin alone group $(0.168 \pm 0.054)$. Indicating that TYK may improve the function of islet B-cell.

\section{Medium term (7 to 12 months)}

Zhu 2004 examined three groups of patients over a 12 month follow-up (insulin, insulin with Chinese medicine and SU). The FCP was $0.84 \mathrm{nmol} / \mathrm{L}$ (SD 0.56) in the insulin group, $0.82 \mathrm{nmol} / \mathrm{L}$ (SD 0.35) in the SU group and $0.87 \mathrm{nmol} / \mathrm{L}$ (SD 0.54) in the insulin and Chinese medicine group at baseline. This changed to $1.12 \mathrm{nmol} / \mathrm{L}$ (SD 0.62) in the insulin group, $1.16 \mathrm{nmol} / \mathrm{L}$ (SD 0.67) in the insulin and Chinese medicine group, and $0.94 \mathrm{nmol} / \mathrm{L}$ (SD 0.42) in the SU group. There was no significant difference between the groups.

Zhou 2005 examined insulin alone $(n=7)$ compared to insulin and rosiglitazone $(n=7)$ over 12 months. The median FCP was 0.41 $\mathrm{nmol} / \mathrm{L}$ (range 0.3 to 1.88 ) for the insulin group and $0.52 \mathrm{nmol} /$ $\mathrm{L}$ (range 0.35 to 1.22 ) for the insulin and rosiglitazone group at baseline. At 12 months there was no significant difference between the two groups (insulin only group: FCP $0.48 \mathrm{nmol} / \mathrm{L}$ (range 0.14 to 0.62 ) compared to insulin plus rosiglitazone $F C P 0.52 \mathrm{nmol} / \mathrm{L}$ (range 0.14 to 1.24). However, stimulated C-peptide (after a $2 \mathrm{~h}$ glucose load) showed a difference at 12 months between the groups (insulin alone at baseline median $1.7 \mathrm{nmol} / \mathrm{L}$ (range 0.44 to 6.33 ) and insulin plus rosiglitazone at baseline $1.27 \mathrm{nmol} / \mathrm{L}$ (range 0.46 to 2.51 ) compared to insulin at 12 months with FCP $0.61 \mathrm{nmol} / \mathrm{L}$ (range 0.42 to 2.61 ) and insulin plus rosiglitazone $1.33 \mathrm{nmol} / \mathrm{L}$ (range 0.39 to 2.94)).

Cabrera-Rode 2002 examined insulin with SU and insulin alone. There were no significant differences in FCP between groups after 12 months (insulin $0.32 \mathrm{pmol} / \mathrm{L}$ (SD 0.28 ) at baseline and insulin plus SU at baseline $0.29 \mathrm{pmol} / \mathrm{L}$ (SD 0.28) compared to insulin alone $0.24 \mathrm{pmol} / \mathrm{L}$ (SD 0.25) at 12 months and insulin plus SU $0.2 \mathrm{pmol} / \mathrm{L}$ (SD 0.17) at 12 months).

Li 2009 examined insulin alone $(n=18)$ compared with insulin plus 1-alp hydroxyl-vitamin D3 $(n=17)$. FCP and two hours after a 75 gram glucose load (PCP) were measured at 6 and 12 months. This study found that both FCP and PCP levels remained steady in the insulin plus vitamin D group, with FCP changing from 248 to 261 $\mathrm{pmol} / \mathrm{L}(\mathrm{P}=0.469)$ and $\mathrm{PCP}$ from 587 to $614 \mathrm{pmol}(\mathrm{P}=0.717)$. In contrast, FCP levels decreased in the insulin-alone group (from 368 to $179 \mathrm{pmol} / \mathrm{L}, \mathrm{P}=0.006$ ), with $\mathrm{PCP}$ levels showing a trend towards decline (from 804 to $713 \mathrm{pmol} / \mathrm{L}, \mathrm{P}=0.088$ ). Seventy percent of 
patients treated with vitamin D maintained or increased their FCP concentrations after one year of treatment. In comparison, $22 \%$ of patients treated with insulin alone maintained stable FCP levels. Further analysis on LADA subgroups (with different durations of diabetes) demonstrated that islet B-cell function was better preserved (as reflected by significantly higher FCP and PCP levels) in the insulin plus vitamin $D$ group only in patients with diabetes duration no longer than one year.

\section{Long term (more than 12 months)}

Zhou 2005 examined insulin alone compared to insulin with rosiglitazone. At 18 months there was no significant difference between groups but the insulin group FCP had significantly declined when compared to baseline. This was not seen in the insulin plus rosiglitazone group (baseline insulin group median FCP $0.41 \mathrm{nmol} / \mathrm{L}$ (range 0.3 to 1.83 ), 18 month insulin group $0.29 \mathrm{nmol} / \mathrm{L}$ (range 0.04 to 0.66 ) compared to insulin plus rosiglitazone baseline $0.52 \mathrm{nmol} / \mathrm{L}$ (range 0.35 to 1.22 ), 18 month median $0.4 \mathrm{nmol} / \mathrm{L}$ (range 0.13 to 1.1 ). However, stimulated C-peptide significantly differed between the two groups at 18 months (insulin stimulated C-peptide at 18 months $0.41 \mathrm{nmol} / \mathrm{L}$ (range 0.11 to 1.43 ) compared to insulin and rosiglitazone $1.37 \mathrm{nmol} / \mathrm{L}$ (range 0.2-3.95)).

Maruyama 2003 was an RCT examining insulin $(n=24)$ compared to $\mathrm{SU}(\mathrm{n}=30)$ treatment over a four year period. HbA1c, FBG and FCP were not measured. The primary outcome measure was serum $C$ peptide response during a $75 \mathrm{~g}$ oral glucose tolerance test (o-GTT) and the integrated values of serum C-peptide at 0, 30, 60, 90 and 120 minutes during the o-GTT. The integrated C-peptide response rate in the SU group decreased from $22.0 \mathrm{ng} / \mathrm{ml}$ (SD 10.6) at baseline to $11.3 \mathrm{ng} / \mathrm{ml}$ (SD 7.5) at 48 months, while the insulin only group changed from $22 \mathrm{ng} / \mathrm{ml}$ (SD 17.0) at baseline to approximately 19 $\mathrm{ng} / \mathrm{ml}$ at four years. The mean difference was $7.7 \mathrm{ng} / \mathrm{ml}(95 \% \mathrm{Cl}$ 2.9 to $12.5, \mathrm{P}<0.01$ ). Therefore, there insulin showed significantly improved integrated C-peptide response in comparison to SU.

Maruyama 2008 an RCT 5 year follow-up on Maruyama 2003 examining insulin ( $n=30$ ) compared to $S U(n=30)$. The primary end point was an insulin-dependent state defined by the sum of serum C-peptide values during an OGTT of less than $4 \mathrm{ng} / \mathrm{ml}(1.32$ $\mathrm{nmol} / \mathrm{L}$ ). The progression rate to an insulin dependent state in the insulin group (three of $30,10 \%$ ) was lower than that in the SU group (13 of 30, 43\%; $P=0.0003$ log-rank). Multiple regression analysis demonstrated that insulin treatment $(P<0.001)$, a preserved $C$ peptide response $(P=0.001)$ at entry were independent factors in preventing progression to an insulin-dependent state.Subgroup analysis suggested that insulin intervention was highly effective for LADA.

Kobayashi 1996 examined insulin compared to SU using stimulated C-peptide response. There was no significant difference between the groups at 30 months in terms of integrated value of the $C$ peptide response at $0,30,60,90,120$ and 180 minutes. However, the SU group decreased significantly from baseline (approximately $7.1 \mathrm{nmol} / \mathrm{L}$ in the SU baseline integrated CPR and approximately 4.1 $\mathrm{nmol} / \mathrm{L}$ at 30 months, compared to approximately $5.9 \mathrm{nmol} / \mathrm{L}$ in the insulin group at baseline and $9 \mathrm{nmol} / \mathrm{L}$ at 30 months).

Yang 2009 examined (follow-up 3 years) a rosiglitazone group ( $\mathrm{n}=$ $15)$ or SU group ( $n=14$ ) for patients with GADA $<175$ WHO Units $/ \mathrm{mL}$ and FCP $>0.3 \mathrm{nmol} / \mathrm{L}$. For patients with GADA $\geq 175 \mathrm{WHO}$ Units $/ \mathrm{mL}$ and $\mathrm{FCP} \leq 0.03 \mathrm{nmol} / \mathrm{L}$ then they were assigned to insulin alone $(n=12)$ or rosiglitazone plus insulin $(n=12)$. The levels of stimulated C-peptide (PCP) and delta C-peptide (CP) levels were higher in the rosiglitazone group (PCP $3.3 \mathrm{mmol} / \mathrm{L} \mathrm{CP} 2.4 \mathrm{mmol} / \mathrm{L}$ ) compared to the SU group (PCP $2 \mathrm{mmol} / \mathrm{L}, \mathrm{CP} 1.3 \mathrm{mmol} / \mathrm{L}$ ) after 18 months. Also stimulated C-peptide and C-peptide levels after 18 months in the insulin and rosiglitazone group (PCP $0.7 \mathrm{mmol} / \mathrm{L}, \mathrm{CP} 1 \mathrm{mmol} / \mathrm{L}$ ) were higher than those in the insulin alone group (PCP $0.5 \mathrm{mmol} /$ $\mathrm{L}, \mathrm{CP} 0.25 \mathrm{mmol} / \mathrm{L})$. The levels of stimulated C-peptide (PCP) and delta $\mathrm{C}$-peptide (CP) levels were higher in the rosiglitazone group (PCP $2.7 \mathrm{mmol} / \mathrm{L} \mathrm{CP} 2.2 \mathrm{mmol} / \mathrm{L}$ ) compared to the SU group (PCP 1.8 $\mathrm{mmol} / \mathrm{L}, \mathrm{CP} 1.4 \mathrm{mmol} / \mathrm{L}$ ) after 36 months. Also stimulated C-peptide and $C$-peptide levels after 36 months in the insulin and rosiglitazone group (PCP $1.1 \mathrm{mmol} / \mathrm{L}, \mathrm{CP} 0.7 \mathrm{mmol} / \mathrm{L}$ ) were higher than those in the insulin alone group (PCP $0.3 \mathrm{mmol} / \mathrm{L}, \mathrm{CP} 0.1 \mathrm{mmol} / \mathrm{L}$ ).

Agardh 2009 a 5 year follow-up of an RCT examining GAD65 shown that fasting C-peptides levels declined in the placebo group (-0.24; $95 \% \mathrm{Cl}-0.41$ to $-0.07 \log \mathrm{nmol} / \mathrm{L} ; \mathrm{P}=0.01$ ) and the $500 \mu \mathrm{g}$ dose group $(-37 ; 95 \% \mathrm{Cl}-0.57$ to $-0.17 \log \mathrm{nmol} / \mathrm{L} ; \mathrm{P}=0.003)$, but not in the $4 \mu \mathrm{g}$ $(-0.10 ; 95 \% \mathrm{Cl}-0.28$ to $0.07 \log \mathrm{nmol} / \mathrm{L} ; \mathrm{P}=0.20 \mu \mathrm{g}(0.04 ; 95 \% \mathrm{Cl}-0.12$ to $0.19 \log \mathrm{nmol} / \mathrm{L} \mathrm{P}=0.58)$ and $100 \mu \mathrm{g}(0.00 ; 95 \% \mathrm{Cl}-0.20$ to -0.20 $\log \mathrm{nmol} / \mathrm{L} ; \mathrm{P}=0.98$ ) dose groups. It appears the increase in fasting and stimulated C-peptide levels that had previously been reported Agardh 2005 after 6 months in the $20 \mu \mathrm{g}$ was maintained during the 5 year follow-up.

Thunander 2010 a 3 year follow-up examined insulin compared to conventional treatment. This showed the stimulated C-petide decreased significantly from baseline for both groups (mean glucagon-stimulated C-peptide ( $\mathrm{nmol} / \mathrm{L}$ ) at baseline 1.2 (SD 0.7) and 36 months 0.73 (SD 0.6) in the insulin group compared to 1.7 (SD 0.9 ) and $1.3(0.9)$ in the tablet group respectively), but no significant difference between groups.

In summary, GAD65 may have an effect in maintaining C-peptide levels in the short term. However, there does not appear to be any significant difference in insulin compared to SU treatment in maintaining fasting C-peptide levels. Stimulated C-peptide may be maintained more with insulin compared to SU and more with insulin and rosiglitazone than with insulin alone in the long-term. In addition, herbal Chinese remedies such as TYK and the use of vitamin $D$ may have a part to play in the preservation of B-cells in people with LADA.

\section{Health-related quality of life}

No included study reported on health-related quality of life. One abstract (Scranton 2004) was available that reported on quality of life outcomes. However, this abstract was excluded as it did not mention antibody tests in the selection criteria of patients with latent autoimmune diabetes in adults (LADA).

Health service utilization and costs, hypertension, hyperlipidaemia, lipid profile, microalbuminuria

No study reported on these secondary outcome measures.

\section{DISCUSSION}

\section{Summary of main results}

This review systematically examined fifteen publications (ten studies) of interventions aimed at latent autoimmune diabetes in adults (LADA) . No studies reported on secondary complications of diabetes, instead proxy measures associated with the development 
of complications were used such as metabolic control (glycosylated haemoglobin A1c (HbA1c), fasting blood glucose) and natural insulin productions levels (C-peptide) were reported. There are very early pilot data that GAD65 may improve metabolic control. There are no data on the effects of oral agents such as metformin or glitazones alone. Rosiglitazone with insulin or sulphonylureas (SU) with insulin did not improve metabolic control significantly more than insulin alone. However, insulin combined with Chinese medicine improved metabolic control when compared to SU. There is evidence that metabolic control in terms of $\mathrm{HbAlc}$ is improved using insulin when compared to tablet treatment (SU). Vitamin D appears to protect the beta-cells when given with insulin compared to insulin alone.

No studies on oral agents or insulin reported adverse events in terms of severe hypoglycaemic attacks. However, the trial with glutamic acid decarboxylase (GAD) 65 reported a number of nonhypoglycaemic adverse events.

There is not enough evidence to examine if any intervention (insulin or SU or glitazone with insulin) affects fasting C-peptide (FCP) levels. GAD65 may maintain C-peptide levels better than placebo in the short term and has shown to be maintained in a certain GAD65 dosage group $(20 \mu \mathrm{g})$ in the longer term. Stimulated C-peptide was maintained better with insulin than with SU and better with rosiglitazone and insulin together compared to insulin alone.

\section{Overall completeness and applicability of evidence}

These results are difficult to generalise as there is a great deal of heterogeneity between studies; differences in selection criteria for LADA (Appendix 2), some studies stratifying patients by FBG or GADA titre before randomisation, small sample sizes and lack of description of treatment regimes. In addition, the measurement of the same outcome, C-peptide, was performed differently in every study ranging from an integrated serum Cpeptide value (Maruyama 2003), glucagon-stimulated C-peptide (Thunander 2010) and glucose stimulated delta C-peptide (Yang 2009). Therefore, these findings are difficult to compare between studies and to generalise.

\section{Quality of the evidence}

The findings of this review represent very early days in our understanding of the best ways of treating LADA as some of the findings are based on studies that were not aimed at LADA patients but were actually aimed at type 2 patients in which retrospective analysis identified some antibody positive patients (Davis 2005; L-Hallin 1999). Others have used outcome measures that are difficult to understand by clinicians and are perhaps only relevant to research studies (Maruyama 2003). There is a great deal of heterogeneity in the studies which does affect the meta-analysis' generalizability.

\section{Potential biases in the review process}

There are very few studies examining interventions for LADA. In the studies that exist the selection criteria for LADA varied greatly, some had very low numbers of patients and showed poor quality of reporting the findings (studies selected did not report on randomisation, allocation concealment, follow-up, treatment regimes (for example what insulin regime, what type of conventional treatment, blinding of the analysis, and there was no CONSORT statement for any of the studies) (Figure 4, Figure 5). 
Figure 4. Methodological quality summary: review authors' judgements about each methodological quality item for each included study.

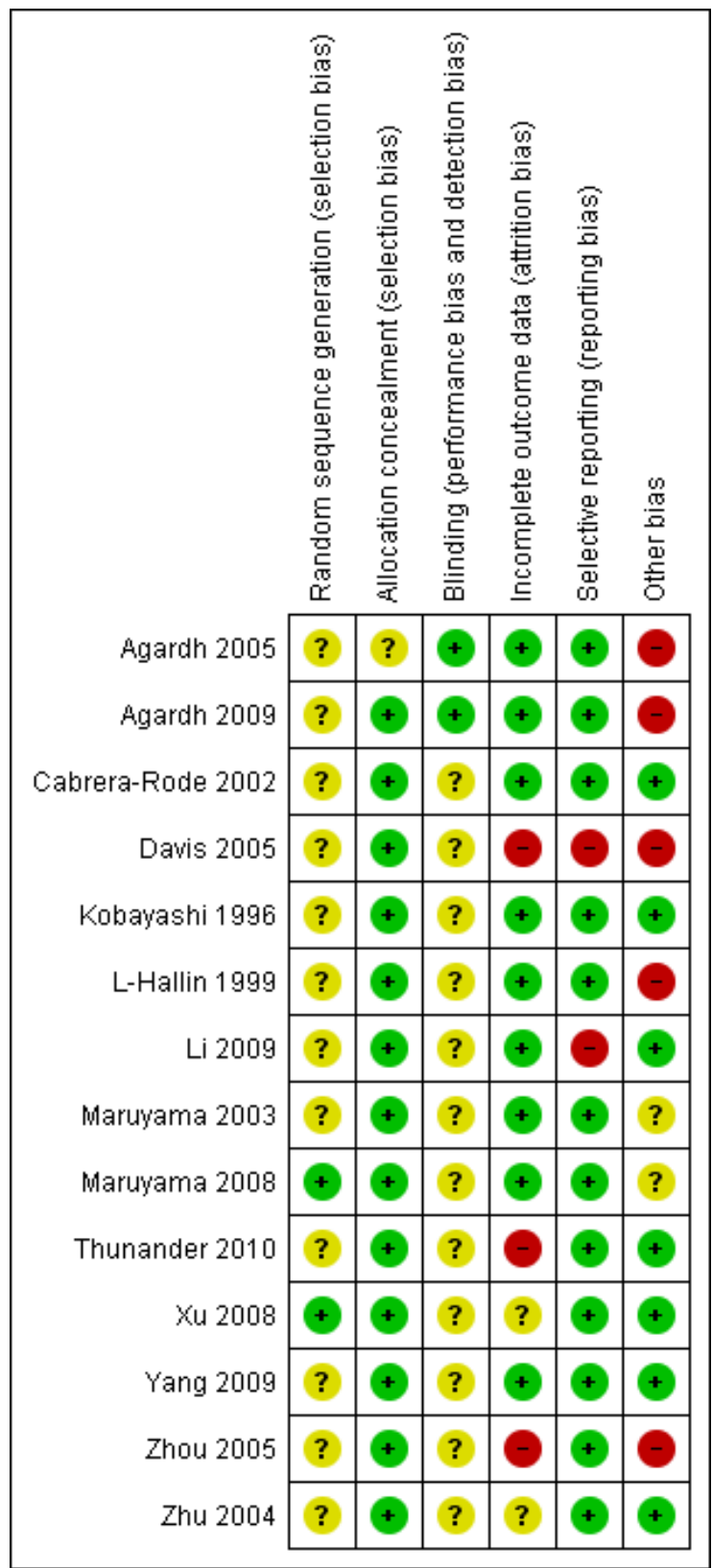


Figure 5. Methodological quality graph: review authors' judgements about each methodological quality item presented as percentages across all included studies.

Random sequence generation (selection bias)

Allocation concealment (selection bias)

Blinding (performance bias and detection bias)

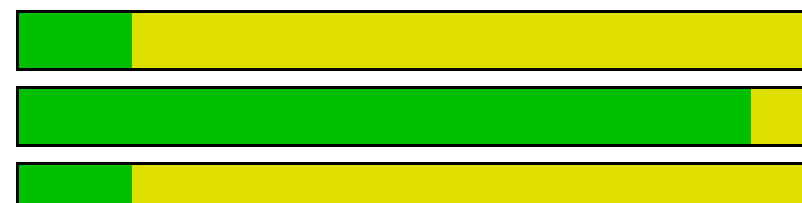

\section{Incomplete outcome data (attrition bias) \\ Selective reporting (reporting bias) \\ $\square$ Lw risk of bias
$\square$ Unclear
ements and disagreements with other studies or}

Other bias

No other systematic reviews have been conducted on this topic.

\section{Other on-going studies.}

Current ongoing studies are: Buzzetti 2006 examining insulin compared to metformin, Grill 2010 examining metformin and insulin compared to metformin and sitagliptin +/- repaglinide, Zhou 2010 examining sitagliptin combined with insulin compared to sitagliptin alone. In addition, number of studies have been started but are no longer ongoing; 1. DiaPep277 for LADA: A Study entitled "Safety, tolerability, immunological and clinical efficacy of multiple subcutaneous doses of DiaPep277 in LADA" was found at the Phase II level to not give enough benefit to continue to the Phase III level. Therefore, the plan to continue with the DiaPep277 trial was stopped. (Palmer 2009). The findings from the Phase II trial have still not been published. 2. Insulin compared to standard care (diet, metformin, metformin with or without glitazones). The primary investigator is $\operatorname{Dr} \mathrm{S}$ Brophy (author of this review) in Swansea University (Brophy 2007). This study closed early due to over $70 \%$ of potential participants being initiated on insulin before they could be recruited to the trial. Therefore putting them in the exclusion criteria. The results at closure of study have just been written up (Brophy 2011). 3. A phase II/III level RCT to investigate if a prime and boost of 20ug Diamyd ${ }^{\circledR}$ (rhGAD65 formulated in Alhydroge ${ }^{\circledR}$ ), administered subcutaneously four weeks apart, can preserve insulin production in patients with Latent Autoimmune Diabetes in Adult (LADA) started in April 2007. The primary investigator is Diamyd Therapeutics AB. This study is registered as ongoing but is not currently recruiting patients (Agardh 2004). 4. Rosiglitazone and sulphonylurea (SU): A study which compares rosiglitazone with SU is registered as starting in 2000 with results currently being written up but are not yet published (confirmed by email with Palmer (Palmer 2000). The study examines fasting C-peptide, antibody levels over three years in 60 patients treated either with rosiglitazone or SU. The primary investigator is Dr Jerry Palmer at Washington University. 5. Oral Insulin: E-Longmire 2004 examined if oral insulin improved endogenous insulin retention in insulin dependent diabetes. It was found that oral insulin treatment improved C-peptide responses in patients diagnosed at ages greater than 20 years, best seen at the low $(1 \mathrm{mg}$ per day) over the high (10 mg per day) insulin dose ( $P=0.003$ and $P$ $=0.01$, respectively). In patients diagnosed before age 20 years, the $1 \mathrm{mg}$ dose was ineffective, whereas the $10 \mathrm{mg}$ dose actually accelerated $C$-peptide loss $(P=0.003)$. The authors concluded that "if confirmed, these findings suggest that diabetic patients over age 20 years with ICA evidence of late-onset immune-mediated diabetes should be considered for oral insulin at $1 \mathrm{mg} /$ day to better retain endogenous insulin secretion". This study is relevant, but failed to provide details of numbers of patients treated, loss to follow-up, intention-to-treat and methods of randomisation or concealment of treatment during analysis. Therefore, the results were not reported as part of this review.

\section{AUTHORS' CONCLUSIONS}

\section{Implications for practice}

There is no significant evidence that sulphonylureas (SU) could be preferable to other forms of treatment of latent autoimmune diabetes in adults (LADA). Some evidence from meta-analysis suggests that insulin is preferable for metabolic control (however, there is considerable heterogeneity) and there is some evidence that SU may bring about earlier insulin dependence (Davis 2005; Maruyama 2003; Maruyama 2008). Therefore, SU should not be a first line treatment agent of antibody positive LADA patients. However, this review has not found any evidence to chose or reject any other possible intervention. Taking results from Davis 2005, patients who are poorly controlled in the beginning and are antibody positive are likely to progress to insulin quickly. Antibody positive patients who have good control can remain on standard treatment (oral therapy excluding SU) until insulin treatment is needed for control. Taking results from Maruyama 2003, patients with high glutamic acid decarboxylase (GAD) titre may be less likely to progress to insulin dependence if given insulin early. Therefore, poorly controlled, high GAD titre patients could 
benefit from early insulin. Other innovative therapies administered with insulin, including vitamin $D$ and Chinese remedies appear to preserve beta cell function better than insulin alone. There is early evidence that GAD65 may be useful in LADA.

\section{Implications for research}

There is a need for more high quality trials investigating therapies (both established and innovative) in LADA with longer-term followup. Further studies are required to examine:

- Insulin treatment compared to metformin or glitazones (with the exception of rosiglitazone) for metabolic control and Cpeptide levels.

- Impact of different treatment strategies on long-term complications of LADA (retinopathy, neuropathy, cardiovascular disease, nephropathy) and total mortality.

- Impact of different treatments strategies on health-related quality of life.
- Impact of different treatments on costs and health service utilization.

Future studies should use the CONSORT statement and should perform power calculations. It would improve generalizability if future studies recorded clinically relevant outcomes such as $\mathrm{HbA1c}$ or fasting glucose levels, if a standard definition of LADA and a common method of measuring stimulated C-peptide could be used.

\section{ACKNOWLEDGEMENTS}

We would like to thank the authors who responded to our questions regarding this review: Dr Zhou, Professor Scranton, Dr Kristian Lynch, Professor Holman, Dr Ergun-Longmire and Dr LandstedtHallin. We would like to thank Dr Wei-yee Cheung and S Lee for their help in reading and critically appraising the non-English language articles. 


\section{R E F E R E N C E S}

\section{References to studies included in this review}

Agardh 2005 \{published data only\}

Agardh C-D, Cilio C, Lethagen A, Lynch K, Leslie D, Palmer M, et al. Clinical evidence for the safety of GAD65 immunomodulation in adult-onset autoimmune diabetes. Journal of diabetes and its complications 2005;19:238-46.

Agardh 2009 \{published data only\}

Agardh C-D, Lynch K, Palmer M, Link K. GAD65 vaccination: 5 years of follow-up in a randomised dose-escalating study in adult-onset autoimmune diabetes. Diabetologia 2009;52:1363-68.

\section{Cabrera-Rode 2002 \{published data only\}}

Cabrera-Rode E, Perich P, Diaz-Horta O, Tiberti C, Molina G, Arranz C, et al. Slowly progressing type 1 diabetes: Persistence of islet cell autoantibodies is related to glibenclamide treatment. Autoimmunity 2002;35(7):469-74.

Davis 2005 \{published data only\}

Davis T, Wright A, Mehta Z, Cull C, Stratton I, Bottazzo G, et al. Islet autoantibodies in clinically diagnosed type 2 diabetes: prevalence and relationship with metabolic control [UKPDS 70]. Diabetologia 2005;48:695-702. [MEDLINE: PMID: 15729570]

\section{Kobayashi 1996 \{published data only\}}

Kobayashi T, Nakanishi K, Murase T, Kosaka K. Small doses of subcutaneous insulin as a strategy for preventing slowly progressive beta cell failure in islet cell antibody positive patients with clinical features of NIDDM. Diabetes 1996;45:622-6.

\section{L-Hallin 1999 \{published data only\}}

Landstedt-Hallin L, Arnert P, Lins PE, Bolindert J, Olsen H, Groop $L$ and Scandinavian insulin sulphonylurea study group research team. The role of sulphonylurea in combination therapy assessed in a trial of sulphonylurea withdrawal. Diabetes Medicine 1999;16:827-34.

\section{Li 2009 \{published data only\}}

Li X, Liao L, Yan X, Huang G, Lin J, Lei M, Wang X, Zhou Z. Protective effects of 1-alpha-hydroxyvitamin D3 on residual beta-cell function in patients with adult-onset latent autoimmune diabetes (LADA). Diabetes/Metabolism Research and Reviews 2009;25:411-416.

\section{Maruyama 2003 \{published data only\}}

Maruyama T, Shimada A, Kanatsuka A, Kasuga A, Takei I, Yokoyama J, et al. Multicenter prevention trial of slowly progressive type 1 diabetes with small dose of insulin (the Tokyo Study). Annals of the New York Academy of Sciences 2003;1005:362-9.

\section{Maruyama 2008 \{published data only\}}

Maruyama T, Tanaka S, Shimada A, Funae O, Kasuga A, Kanatsuka A, et al. Insulin Intervention in Slowly Progressive Insulin Dependent (Type 1) Diabetes Mellitus. The Journal of clinical endocrinology and metabolism 2008;93(6):2115-21.
Thunander 2010 \{published data only\}

Thunander M, Thorgeirsson H, Torn C, Petersson C, LandinOlsson M. Beta-cell function and metabolic control in Latent Autoimmune Diabetes in Adults (LADA) with early insulin vs conventional treatment: A three-year follow-up. European Journal of Endocrinology 2011;164:239.

\section{Xu 2008 \{published data only\}}

Xu X, Zhang D. Effect of Tanguikang in improving the function of pancreatic islet beta cells in patients with latent autoimmune diabetes in adults. Chinese Journal of Integrated Traditional and Western Medicine 2008;28(10):882-5.

\section{Yang 2009 \{published data only\}}

Yang Z, Zhou Z, Li X, Huang G, Lin J. Rosiglitazone preserves islet beta-cell function of adult onset latent autoimmune diabetes in 3 years follow-up study. Diabetes Research and Clinical Practice 2009;83:54-60.

\section{Zhou 2005 \{published data only\}}

* Zhou Z, Li X, Huang G, Peng J, Yang L, Yan X, Wang J. Rosiglitazone combined with insulin preserves islet beta cell function in adult-onset latent autoimmune diabetes [LADA]. Diabetes/metabolism research and reviews 2005;21:203-8.

\section{Zhu 2004 \{published data only\}}

* Zhu L-Q, Liu Y-H, Huang M. Study on improvement of islet beta cell function in patients with latent autoimmune diabetes mellitus in adults by integrated Chinese and Western Medicine. Chinese journal of integrated traditional and Western Medicien 2004;24(7):581-4.

\section{References to studies excluded from this review}

\section{Alvarsson 2003 \{published data only\}}

* Alvarsson M, Sundkvist G, Lager I, Henricsson M, Berntorp K, Fernqvist-Forbes $\mathrm{E}$, et al. Beneficial effects of insulin versus sulphonylurea on insulin secretion and metabolic control in recently diagnosed type 2 diabetes patients. Diabetes Care 2003;26(8):2231-7.

\section{Berkis 2007 \{published data only\}}

Berkis LM, Jensen RA, Lagerquist E, Hall TR, Agardh CD, Ciliot CM, et al. GAD65 autoantibody epitopes in adult patients with latent autoimmune diabetes following GAD65 vaccination. Diabetes Medicine 2007;24:521-6.

\section{Bjork 1996 \{published data only\}}

Bjork E, Berne C, Kampe O, Wibell L, Oskarsson P, Karlsson F. Diazoxide treatment at onset preserves residual insulin secretion in adults with autoimmune diabetes. Diabetes 1996;45:1427-30

\section{Chaillous 2000 \{published data only\}}

Chaillous L, Lefevre H, Thivolet C, Boitard C, Lahlou N, AtlanGepner C, et al. Oral insulin administration and residual Beta cell function in recent onset type 1 diabetes: a Multicentre randomised controlled trial. The Lancet 2000;356:545-9. 
Conget 2005 \{published data only\}

Conget I, Aguilera E, Pellitero S, Naf S, Bendtzen K, Casamitjana $\mathrm{R}$, et al. Lack of effect of intermittently administered sodium fusidate in patients with newly diagnosed type 1 diabetes mellitus: the FUSIDM trial. Diabetologia 2005;48:1464-8. [MEDLINE: PMID: 15995847]

\section{DCCT Group 1998 \{published data only\}}

DCCT Research Group. Effect of intensive therapy on residual beta cell function in patients with type 1 diabetes in the diabetes control and complications trial. Annals of Internal Medicine 1998;128(7):517-23.

\section{Desai 2007 \{published data only\}}

Desai M, Cull CA, Horton VA, Christie MR, Bonifacio E, Lampasona, V, et al. GAD autoantibodies and epitope reactivities persist after diagnosis in latent autoimmune diabetes in adults but do not predict disease progression: UKPDS 77. Diabetologia 2007;50:2052-60.

\section{Desai 2008 \{published data only\}}

Desai M, Clark A. Autoimmune diabetes in adults: lessons from the UKPDS. Diabetic Medicine 2008;25 (Suppl 2):30-4.

\section{E-Longmire 2004 \{published data only\}}

Ergun-Longmire B, Marker J, Zeidler A, Rapaport R, Raskin P, Bode $B$, et al. Oral insulin therapy to prevent progression of immune-mediated (type 1) diabetes. Annals of the New York Academy of Sciences 2004;1029:260-77.

\section{Goday 1993 \{published data only\}}

Goday A, Pujol-Borrell R, Fernadez J, Casamitjana R, Rios M, Vilardell E, Gomis R. Effects of a short prednisone regime at clinical onset of type 1 diabetes. Diabetes Research and Clinical Practice 1993;20:39-46.

\section{Heise 2005 \{published data only\}}

Heise T, Bott S, Tusek C, Stephan J-A, Kawabata T, FincoKent $D$, et al. The effect of insulin antibodies on the metabolic action of inhaled and subcutaneous insulin. Diabetes Care 2005;28:2161-9. [MEDLINE: PMID: 16123484]

\section{Karges 2004 \{published data only\}}

Karges B, Durinovic-Bello, Heinze E, Boehm B, Debatin K-M, Karges W. Complete long term recovery of beta cell function in autoimmune type 1 diabetes after insulin treatment. Diabetes Care 2004;27(5):1207-8. [MEDLINE: PMID: 15111548]

\section{Kobayashi 2002 \{published data only\}}

Kobayashi T, Maruyama T, Shimada A, Kasuga A, Kanatsuka A, Takei I, et al. Insulin intervention to preserve beta cells in slowly progressive insulin dependent (type 1) diabetes mellitus. Annals of the New York Academy of Sciences 2002;958:117-30.

\section{Leslie 1996 \{published data only\}}

Leslie R. Intervention in patients with type 1 diabetes masquerading as type II diabetes. Diabetes Nutrition Metabolism 1996;9:319-24
Leslie 2008 \{published data only\}

Leslie RDG, Kolb H, Schloot NC, Buzzetti R, Mauricio D, De Leiva A, et al. Diabetes classification:grey zones, sound and smoke: Action LADA1. Diabetes/Metabolism Research and Reviews 2008;24:511-9.

\section{Linn 1996 \{published data only\}}

Linn T, Ortac K, Laube H, Federlin K. Intensive therapy in adult insulin dependent diabetes mellitus is associated with improved insulin sensitivity and reserve: a randomised, controlled prospective study over 5 years in newly diagnosed patients. Metabolism 1996;45(12):1508-13.

\section{Littorin 1999 \{published data only\}}

Littorin B, Sundkvist G, Hagopian W, Landin-Olsson M, Lernmark A, Ostman J, et al. Islet cell and glutamic acid decarboxylase antibodies present at diagnosis of diabetes predict the need for insulin treatment. Diabetes Care 1999;22(3):409-12.

\section{Loriz Peralta 2007 \{published data only\}}

Loriz Peralta O, Campos Bonilla B, Granda Ybern ML, Sanmarti Sala A, Arroyo Bros J. Detection of LADA-type diabetes in overweight diabetic patients. Is treatment with metformin suitable?. Aten Primaria 2007;39(3):133-7.

\section{Martin 1991 \{published data only\}}

Martin S, Schernthaner G, Nerup J, Gries F, Koivisto V, Dupre J, et al. Follow-up of cyclosporin A, treatment in type 1 (insulin - dependent) diabetes mellitus: lack of long term effects. Diabetologia 1991;34:429-34.

\section{Matsumoto 2005 \{published data only\}}

Matsumoto M, Satou S. Small doses of insulin may prevent the decrease of intrinsic insulin secretion in anti-GAD, ICA and IA-2 antibody-positive slowly progressive type 1 diabetes. Journal of the Japan Diabetes Society 2005;48(4):257-61.

\section{Mattews 1998 \{published data only\}}

Matthews D, Cull C, Stratton I, Holman R, Turner R. UKPDS 26: Sulphonylurea failure in non-insulin dependent diabetic patients over six years. Diabetic medicine 1998;15:297-303.

\section{Mayorov A 2005 \{published data only\}}

Mayorov A, Naumenkova I, Antsiferov M, Dedov I. Influence of insulin treatment on insulin sensitivity in insulin requiring type 2 diabetes patients. Diabetes Research and Clinical Practice 2005;68:S54-S59. [MEDLINE: PMID: 15955377]

\section{Murao 2008 \{published data only\}}

Murao S, Kondo S, Ohashi J, Fujii Y, Shimizu I, Fujiyama M, et al. Anti-thyroid peroxidase antibody, IA-2 antibody and fasting Cpeptide levels predict beta cell failure in patients with latent autoimmune diabetes in adults (LADA). A 5 year follow-up of the Ehime study. Diabetes Research and Clinical Practice 2008;80:114-21.

\section{Ovalle 2004 \{published data only\}}

Ovalle F, Bell D. Effect of Rosiglitazone versus insulin on the pancreatic beta cell function of subjects with type 2 diabetes. Diabetes Care 2004;27(11):2585-9. [MEDLINE: PMID: 15504990] 
Pozzilli 1997 \{published data only\}

Pozzilli P, Visalli N, Cavallo M, Signore A, Baroni M, Buzzetti R et al and the IMDIAB study Group. Vitamin E and nicotinamide have similar effects in maintaining residual beta cell function in recent onset insulin dependent diabetes (the IMDIAB IV study). European Journal of Endocrinology 1997;137:234-9.

\section{Pozzilli 2000 \{published data only\}}

Pozzilli P, Pitocco D, Visalli N, Cavallo G, Buzzetti R, Crino A, et al. No effect of oral insulin on residual beta-cell function in recent-onset type 1 diabetes (the IMDIAB VII). Diabetologia 2000;43:1000-4.

\section{Pugliese 2003 \{published data only\}}

Pugliese A. Peptide-based treatment for autoimmune diseases: learning how to handle a double-edged sword. Journal of Clinical Investigation 2003;111:1280-2.

\section{Ravnik-Oblak 1995 \{published data only\}}

Ravnik-Oblak M, Mrevlje F. Insulin versus a combination of insulin and sulphonylurea in the treatment of NIDDM patients with secondary oral failure. Diabetes Research and Clinical Practice 1995;30:27-35.

\section{Raz 2007 \{published data only\}}

Raz I, Avron A, Tamir M, Metzger M, Symer L, Eldor R, et al. Treatment of new-onset type 1 diabetes with peptide DiaPep277 is safe and associated with preserved beta-cell function: extension of a randomised, double-blind, phase II trial. Diabetes/Metabolism Research and Reviews 2007;23:292-8.

\section{Rosario 2007 \{published data only\}}

Rosario PWS, Reis JS, Fagundes TA, Calsolari MR, Amim R, Silva SC, et al. Latent Autoimmune Diabetes in Adults (LADA): Usefulness of Anti-Gad Antibody Titers and Benefit of Early Insulinization. Arquivos Brasileiros de Endocrinologia e Metabologia 2007;51/1:52-8.

\section{Sa 2003 \{published data only\}}

Sa J, Silva R, Nasri F, Velloso L, Chacra A, Dib S. Non-obese adult onset diabetes with oral hypoglycaemic agent failure: islet cell autoantibodies or reversible beta cell refractoriness?. Brazillian Journal of Medical and Biological Research 2003;36:1301-9.

\section{Schloot 2007 \{published data only\}}

Schloot NC, Meierhoff G, Lengyel C, Vandorfi G, Takacs J, Panczel P, et al. Effect of heat shock protein peptide DiaPep277 on Beta-cell function in paediatric and adult patients with recent-onset diabetes mellitus type 1: two prospective, randomised, double-blind phase II trials. Diabetes/Metabolism Research and Reviews 2007;23:276-85

\section{Schories 2004 \{published data only\}}

Schories M, Peters T, Rasenack J, Reincke M. Islet-cell antibodies and type 1 diabetes after treatment with interferon-alpha. Deutsche Medizinische Wochenschrift 2004;129:1120-4. in adults [LADA]. American Diabetes Association. 2004:Abstract number: $1835-\mathrm{P}$.

Secchi 1990 \{published data only\}

Secchi A, Pastore M, Sergi A, Pontiroli A, Pozza G. Prednisone administration in recent onset type 1 diabetes. Journal of autoimmunity 1990;3:593-600.

Steffes 2003 \{published data only\}

Steffes M, Jackson M, Sibley S, Thomas W. Beta cell Function and the development of diabetes related complications in the diabetes control and complications trial. Diabetes Care 2003;26(3):832-6.

\section{Stenstrom 2005 \{published data only\}}

Stenstrom G, Gottsater A, Bakhtadze E, Berger B, Sundkvist G. Latent autoimmune diabetes in adults: Definition, prevalence, Beta cell function and treatment. Diabetes 2005;54(S2):S68-S72.

Takino 1998 \{published data only\}

Takino H, Yamasaki H, Sera Y, Abe T, Ozaki M, Kondo H, et al. The preliminary report from the nation-wide prevention study for type 1 diabetes initially diagnosed as type 2 in Japan. Diabetes/ metabolism reviews 1998;14:329-35.

\section{Turner 1997 \{published data only\}}

Turner R, Stratton I, Horton V, Manley S, Zimmet P, Mackay I, et al. UKPDS 25: autoantibodies in islet-cell cytoplasm and glutamic acid decarboxylase for prediction of insulin requirement in type 2 diabetes. The Lancet 1997;350:1288-93.

\section{van Deutekom 2007 \{published data only\}}

van Deutekom AW, Heine RJ, Simsek S. The islet autoantibody titre: their clinical relevance in latent autoimmune diabetes in adults (LADA) and the classification of diabetes mellitus. Diabetic Medicine 2007;25:117-25.

Vidal 2000 \{published data only\}

Vidal J, Fernandez-Balsells M, Sesmilo G, Aguilera E, Casamitjana R, Gomis R, et al. Effects of Nicotinamide and intravenous insulin therapy in newly diagnosed type 1 diabetes. Diabetes Care 2000;23(3):360-4.

\section{Weng 2008 \{published data only\}}

Weng J, Li Y, Xu W, Shi L, Zhang Q, Zhu D, et al. Effect of intensive insulin therapy on Beta-cell function and glycaemic control in patients with newly diagnosed type 2 diabetes: a Multicentre randomised parallel-group trial. Lancet 2008;May 24:1753-60.

\section{Zinman 2004 \{published data only\}}

Zinman B, Kahn SE, Haffner SM, O'Neill MC, Heise MA, Freed MI, ADOPT Study Group. Phenotypic Characteristics of GAD antibody positive recently diagnosed patients with type 2 diabetes in north America and Europe. Diabetes 2004;53:3193-200. [MEDLINE: PMID: 15561950]

\section{Scranton 2004 \{published data only\}}

Scranton R, Su M, Turner R, Testa M. Quality of life considerations for insulin versus oral agent therapy in persons presenting with characteristics of latent autoimmune diabetes 


\section{References to ongoing studies}

Agardh 2004 \{unpublished data only\}

Safety of Diamyd ${ }^{\circledR}$ in Patients With LADA (Latent Autoimmune Diabetes in Adult). Ongoing study December 2004.

\section{Brophy 2007 \{unpublished data only\}}

Randomised, controlled, parallel-group study to investigate the clinical effectiveness of early insulin treatment in patients with LADA. Ongoing study 2007.

\section{Buzzetti 2006 \{unpublished data only\}}

Non Insulin Requiring Autoimmune Diabetes (NIRAD) project. Ongoing study 2006

\section{Grill 2010 \{unpublished data only\}}

Is "Beta Cell Rest" by Insulin Treatment Beneficial Compared to State-of-the Art Enhancers of Insulin Secretion in Preserving Beta Cell Function in Subjects With Latent Autoimmune Diabetes of the Adult (LADA)?. Ongoing study March 2009.

Palmer 2000 \{unpublished data only\}

Rosiglitazone intervention study on patients with type 1.5 diabetes. Ongoing study 2000.

\section{Palmer 2009 \{unpublished data only\}}

Safety, Tolerability, Immunological and Clinical Efficacy of Multiple Subcutaneous Doses of DiaPep277 in Latent Autoimmune Diabetes in Adults (LADA). Ongoing study October 2002.

\section{Zhou 2010 \{unpublished data only\}}

Protective Effects of Sitagliptin on $\beta$ Cell Function in Patients With Adult-onset Latent Autoimmune Diabetes(LADA) (DPPVLADA) . Ongoing study May 2010.

\section{Additional references}

\section{Amori 2007}

Amori RE, Lau J, Pittas AG. Efficacy and safety of incretin therapy in type 2 diabetes: systematic review and metaanalysis. JAMA 2007;298(2):194-206.

\section{Appel 2009}

Appel SJ, Wadas TM, Rosenthal RS, Ovalle F. Latent autoimmune diabetes of adulthood (LADA): an often misdiagnosed type of diabetes mellitus. Journal of the American Academy of Nurse Practitioners 2009;21(3):156-9.

\section{Beales 2002}

Beales P, Pozzilli P. Thiazolidinediones for the prevention of diabetes in the non-obese diabetic (NOD) mouse: implications for human type 1 diabetes. Diabetes/Metabolism Research and Reviews 2002;18(2):114-7.

\section{Bingley 2003}

Bingley P, Bonifacio E, Mueller P. Diabetes Antibody Standardization Program, first assay proficiency evaluation. Diabetes 2003;52(5):1128-36.

\section{Black 2003}

Black C, McIntyre L, Mesa-Perez JA, Royle PL, Thomas S, Waugh N. Meglitinide analogues for type 2 diabetes mellitus. Cochrane Database of Systematic Reviews 2003, Issue 4. [DOI: 10.1002/14651858.CD004654.pub2]

\section{Brophy 2006}

Brophy S, Williams D.R.R, Leslie D on behalf of the Action LADA Research Group. Epidemiology of latent autoimmune diabetes [LADA] in eight centres in Europe. Diabetic medicine. 2006; Vol. 23:4 Suppl. [ISSN 0742-3071]

\section{Brophy 2011}

Brophy S, Davies H, Dunseath G, Stephens JW, Platts J, Lane H, et al. Experience of the introduction of routine antibody testing in primary care and of running a trial for latent autoimmune diabetes in adults (LADA). Diabetes research and clinical practice 2011;Epub ahead of print ((Apr 2011)).

\section{Cabrera-Rode 2002}

Cabrera-Rode E, Perich P, Diaz-Horta O, Tiberti C, Molina G, Arranz D, et al. Slowly progressing type 1 diabetes: persistence of islet cell autoantibodies is related to glibenclamide treatment. Autoimmunity 2002;35(7):469-74.

\section{Cohen 1960}

Cohen J. A coefficient of agreement for nominal scales. Educational and Psychological Measurement 1960;20:37-46.

\section{Davies 2008}

Davies H, Brophy S, Fielding A, Bingley P, Chandler M, Hilldrup I, et al. Latent autoimmune diabetes in adults (LADA) in South Wales: incidence and characterization. Diabetic Medicine 2008;25:1354-7.

\section{Gale 2005}

Gale E. Latent autoimmune diabetes in adults: a guide for the perplexed. Diabetologia 2005;48:2195-9.

\section{Higgins 2002}

Higgins JPT, Thompson SG. Quantifying heterogeneity in a meta-analysis. Statistics in medicine 2002;21:1539-58.

\section{Higgins 2003}

Higgins JP, Thompson SG, Deeks JJ, Altman DG. Measuring inconsistency in meta-analysis. BMJ 2003;327(7414):557-60.

\section{Higgins 2005}

Higgins JPT, Green S, editors. Cochrane Handbook for Systematic Reviews of Interventions 4.2.5 [updated May 2005] In: The Cochrane Library, Issue 3, 2005. Chichester, UK: John Wiley \& Sons, Ltd.

\section{Higgins 2011}

Higgins JPT, Green S (editors). Cochrane Handbook for Systematic Reviews of Interventions Version 5.1.0 [updated March 2011]. The Cochrane Collaboration, 2011. Available from www.cochrane-handbook.org. 


\section{Kobayashi 1996}

Kobayashi T, Nakanishi K, Murase T, Kosaka K. Small doses of subcutaneous insulin as a strategy for preventing slowly progressive beta-cell failure in islet cell antibodypositive patients with clinical features of NIDDM. Diabetes 1996;45(5):622-6.

\section{Kobayashi 2002}

Kobayashi T, Maruyama T, Shimada A, Kasuga A, Kanatsuka A, Takei I, et al. Insulin intervention to preserve beta cells in slowly progressive insulin-dependent (type 1) diabetes mellitus. Annals of the New York Academy of Sciences 2002;958:117-30.

\section{Lau 2006}

Lau J, loannidis JPA, Terrin N, Schmid CH, Olkin I. The case of the misleading funnel plot. BMJ 2006;333:597-600.

\section{Leslie 2006}

Leslie R.D, Williams D.R.R, Pozzelli P. Type 1 diabetes and latent autoimmune diabetes in adults (LADA): one end of the rainbow. Journal of Clinical Endocrinology and Metabolism 2006;91(5):1654-9.

\section{Lewis 2001}

Lewis S, Clarke M. Forest plots: trying to see the wood and the trees. BMJ 2001;322(7300):1479-80.

\section{Liberati 2009}

Liberati A, Altman DG, Tetzlaff J, Mulrow C, Gøtzsche PC, Ioannidis JPA, et al. The PRISMA statement for reporting systematic and meta-analyses of studies that evaluate interventions: explanation and elaboration. PLoS Med 1999;6(7):1-28. [DOI: 10.1371/journal.pmed.1000100]

\section{Lohmann 2001}

Lohmann T, Kellner K, Verlohren HJ, Krug J, Steindorf J, Scherbaum WA, et al. Titre and combination of ICA and autoantibodies to glutamic acid decarboxylase discriminate two clinically distinct types of latent autoimmune diabetes in adults (LADA). Diabetologia 2001;44(8):1005-10.

\section{Maruyama 2003}

Maruyama T, Shimada A, Kanatsuka A, Kasuga A, Takei I, Yokoyama J, et al. Multicenter prevention trial of slowly progressive type 1 diabetes with small dose of insulin (the Tokyo study): preliminary report. Annals of the New York Academy of Sciences 2003;1005:362-9.

\section{Nabhan 2005}

Nabhan F, Emanuele M, Emanuele N, Nabhan F. Latent autoimmune diabetes of adulthood. Unique features that distinguish it from type 1 and 2. Postgraduate Medicine 2005;117(3):7-12.

\section{Naik 2003}

Naik R, Palmer J. Latent autoimmune diabetes in adults (LADA). Reviews in Endocrine and Metabolic Disorders 2003;4:233-41.

\section{Naik 2009}

Naik RG, Brooks-Worrell BM, Palmer JP. Latent autoimmune diabetes in adults. Journal of Clinical Endocrinology and Metabolism 2009;94(12):4635-44.

\section{Owen 2003}

Owen KR, Stride A, Ellard S, Hattersley AT. Etiological investigation of diabetes in young adults presenting with apparent type 2 diabetes. Diabetes Care 2003;26(7):2088-93.

\section{Palmer 2002}

Palmer J. Beta cell rest and recovery - does it bring patients with latent autoimmune diabetes in adults to euglycaemia?. Annals of the New York Academy of Sciences 2002;958:89-98.

\section{Pozzilli 2001}

Pozzilli P, Di Mario U. Autoimmune diabetes not requiring insulin at diagnosis (latent autoimmune diabetes of the adult) definition, characterization and potential prevention. Diabetes Care 2001;24(8):1460-7.

\section{Richter 2006}

Richter Bernd, Bandeira-Echtler Elizabeth, Bergerhoff Karla, Clar Christine, Ebrahim Susanne H. Pioglitazone for type 2 diabetes mellitus. Cochrane Database of Systematic Reviews 2006, Issue 4. [DOI: 10.1002/14651858]

\section{Richter 2007}

Richter Bernd, Bandeira-Echtler Elizabeth, Bergerhoff Karla, Clar Christine, Ebrahim Susanne H. Rosiglitazone for type 2 diabetes mellitus. Cochrane Database of Systematic Reviews 2007, Issue 3. [DOI: 10.1002/14651858]

\section{Richter 2008}

Richter B, Bandeira-Echtler E, Bergerhoff K, Lerch CL. Dipeptidyl peptidase-4 (DPP-4) inhibitors for type 2 diabetes mellitus. Cochrane Database of Systematic Reviews 2008, Issue 2. [DOI: CD006739.pub2]

\section{Saenz 2005}

Saenz Antonio, Fernandez-Esteban Inmaculada, Mataix Angel, Ausejo Segura Monica, Roqué i Figuls Marta, Moher David. Metformin monotherapy for type 2 diabetes mellitus. Cochrane Database of Systematic Reviews 2005, Issue 3. [DOI: 10.1002/14651858]

\section{Schernthaner 2001}

Schernthaner G, Hink S, Kopp H, Muzyka B, Streit G, Kroiss A. Progress in the characterization of slowly progressive autoimmune diabetes in adult patients (LADA or type 1.5 diabetes). Experimental Clinical Endocrinology Diabetes 2001;109:S94-S108.

\section{Scranton 2004}

Scranton R, Su M, Turner R, Testa M. Quality of life considerations for insulin versus oral agent therapy in persons presenting with characteristics of latent autoimmune diabetes in adults [LADA]. American Diabetes Association. 2004:Abstract number: 1835-P. 


\section{Stenstrom 2005}

Stenstrom G, Gottsater A, Bakhtadze E, Berger B, Sundkvist G. Section II: Type 1- related forms of diabetes. Latent autoimmune diabetes in adults. Diabetes 2005;54:S68-S72.

\section{Sterne 2001}

Sterne JAC, Egger M, Davey Smith G. Investigating and dealing with publication and other biases. In: Egger M, Davey Smith G, Altman DG editor(s). Systematic Reviews in Health Care; Meta-analysis in Context. London: BMJ Publishing Group, 2001:189-208.

\section{Takeda 2002}

Takeda H, Kawasaki E, Shimizu I, Konoue E, Fujiyama M, Murao S, et al. Clinical, autoimmune, and genetic characteristics of adult-onset diabetic patients with GAD auto-antibodies in Japan (Ehime Study). Diabetes Care 2002;25(6):995-1001.

\section{Takino 1998}

Takino H, Yamasaki H, Sera Y, Abe T, Ozaki M, Kondo H, et al. The preliminary report from the nation-wide prevention study for type 1 diabetes initially diagnosed as type 2 in Japan. Diabetes/ metabolism reviews 1998;14(4):334-5.

\section{Tuomi 1993}

Tuomi T, Groop L, Zimmet P, Rowley M, Knowles W, MacKay I, et al. Antibodies to glutamic acid decarboxylase reveal latent autoimmune diabetes mellitus in adults with a non-insulindependent onset of disease. Diabetes 1993;42:359-62.

\section{CHARACTERISTICS OF STUDIES}

Characteristics of included studies [ordered by study ID]

\section{Turner 1997}

Turner R, Stratton I, Horton V, Manley S, Zimmet P, Mackay IR, et al. UKPDS 25: autoantibodies to islet-cell cytoplasm and glutamic acid decarboxylase for prediction of insulin requirement in type 2 diabetes. UK Prospective Diabetes Study Group. Lancet 1997;350 (9087):1288-93.

\section{van de Laar 2006}

Van de Laar FA, Lucassen PL, Akkermans RP, Van de Lisdonk EH, De Grauw WJ. Alpha-glucosidase inhibitors for people with impaired glucose tolerance or impaired fasting blood glucose. Cochrane Database of Systematic Reviews 2006, Issue 4. [DOI: CD005061.pub2]

\section{Zhou 2004}

Zhou Z, Li X, Huang G, Peng J, Yang L, Yan X, et al. Rosiglitazone combined with insulin preserves islet beta cell function in adult-onset latent autoimmune diabetes (LADA). Diabetes/ Metabolism Research and Review 2004;21(2):203-8.

\section{Zinman 2004}

Zinman B, Kahn SE, Haffner SM, O'Neill MC, Heise MA, Freed MI. Phenotypic characteristics of GAD antibody-positive recently diagnosed patients with type 2 diabetes in North America and Europe. Diabetes 2004;53(12):3193-200.

* Indicates the major publication for the study

Agardh 2005

Methods RANDOMISED CONTROLLED CLINICAL TRIAL (RCT): yes, parallel RCT

RANDOMISATION RATIO: equal ratio to four groups

NON-INFERIORITY DESIGN: no

EQUIVALENCE DESIGN: no

ETHICS APPROVAL OBTAINED: yes

PATIENT CONSENT OBTAINED: yes

BLINDING OF PATIENT (P), EDUCATOR (E), RESEARCHER (R): $P=$ yes, $E=$ yes, $R=$ unclear

ANALYSIS BY INTENTION TO TREAT: no, exploratory trial

POWER CALCULATION: no

Participants WHO PARTCIPATED:

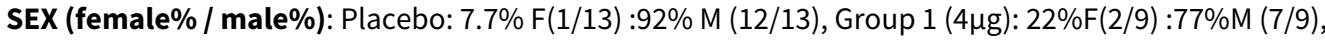

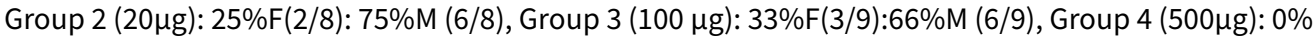
$\mathrm{F}(0 / 8): 100 \% \mathrm{M}(8 / 8)$.

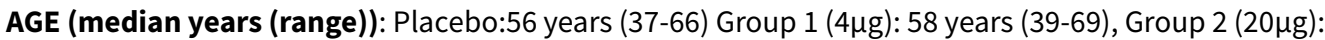
57 years (48-67), Group $3(100 \mu \mathrm{g}): 57$ years (30-69), Group $4(500 \mu \mathrm{g})$ : 53 years (39-62) 
ETHNIC GROUPS (\%): not specified

DURATION OF DISEASE (mean years (SD)): Not given

INCLUSION CRITERIA:(1) Male or female aged 30-70 years (2) diagnosed with type 2 diabetes within the previous 5 years (3) presence of GADA (4) only requiring diabetes treatment with diet, oral hypoglycaemic agents, or both (5) females of non-child-bearing potential (6) absence of associated serious diseases or conditions which, in the opinion of the investigator would exclude the patient from the trial (7) patients who had given written informed consent at the screening visit.

EXCLUSION CRITERIA: not specified

DIAGNOSTIC CRITERIA: Diagnosed with type 2 diabetes within the previous 5 years, presence of GADA, only requiring treatment with diet, oral hypoglycaemic agents or both.

CO-MORBIDITIES:Not given

CO-MEDICATIONS: Not given

NUMBER: Placebo: 13, Group $1(4 \mu \mathrm{g}): 9$, Group $2(20 \mu \mathrm{g}): 8$, Group $3(100 \mu \mathrm{g}): 9$, Group $4(500 \mu \mathrm{g}): 8$

LOSS TO FOLLOW-UP: $0 \%$

Interventions

NUMBER OF STUDY CENTRES:2

COUNTRY/ LOCATION: Sweden

SETTING: out patient

INTERVENTION (ROUTE, TOTAL DOSE/DAY, FREQUENCY): dose comparison of subcutaneous GAD (Diamyd) injections at $4 \mathrm{ug}, 20 \mathrm{ug}, 100 \mathrm{ug}$ or $500 \mathrm{ug}$ doses

CONTROL (ROUTE, TOTAL DOSE/DAY, FREQUENCY): placebo (Alhydrogel)

TREATMENT BEFORE STUDY: All intervention patients received $4 \mu \mathrm{g}$ for 8 weeks. If there were no safety concerns then the higher dose ( $20 \mu \mathrm{g}$ or $100 \mu \mathrm{g}$ or $500 \mu \mathrm{g})$ was initiated.

TITRATION PERIOD: No applicable.

Outcomes

PRIMARY OUTCOME(S) (as stated in the publication): Not stated but objective states "Investigate the clinical safety of subcutaneously administered Diamyd"

SECONDARY OUTCOMES (as stated in the publication): Note stated but objectives states "Assess the impact of Diamyd on the immune system and diabetic status"

\section{ADDITIONAL OUTCOMES:}

Collected at baseline and 24 weeks.

1. HbAlc (\%), 2. Fasting blood glucose (mmol/L), 3. Log GADA (U/ml), 4. C-peptide (nmol/L), 5. BMI (kg/ $\mathrm{m2}), 6$. Adverse events

Study details DURATION OF INTERVENTION: 24 weeks

DURATION OF FOLLOW-UP: 24 weeks

RUN-IN PERIOD: 8 weeks in the intervention group ( $4 \mu \mathrm{g}$ for 8 weeks before higher dose initiated)

Publication details LANGUAGE OF PUBLICATION:English

COMMERCIAL FUNDING: yes

NON-COMMERCIAL FUNDING: no

PUBLICATION STATUS (PEER REVIEW JOURNAL): yeS 
Agardh 2005 (Continued)

PUBLICATION STATUS (JOURNAL SUPPLEMENT): no

PUBLICATION STATUS (ABSTRACT): Full paper

Stated aim for study Quote " To investigate the clinical safety of subcutaneously administered Diamyd and to assess its im-
pact on the immune system and diabetic status"

\section{Notes}

\section{Risk of bias}

\begin{tabular}{|c|c|c|}
\hline Bias & Authors' judgement & Support for judgement \\
\hline $\begin{array}{l}\text { Random sequence genera- } \\
\text { tion (selection bias) }\end{array}$ & Unclear risk & Not given \\
\hline $\begin{array}{l}\text { Allocation concealment } \\
\text { (selection bias) }\end{array}$ & Unclear risk & Unclear how allocation was designed \\
\hline $\begin{array}{l}\text { Blinding (performance } \\
\text { bias and detection bias) } \\
\text { All outcomes }\end{array}$ & Low risk & Double blinded \\
\hline $\begin{array}{l}\text { Incomplete outcome data } \\
\text { (attrition bias) } \\
\text { All outcomes }\end{array}$ & Low risk & No incomplete outcome data given \\
\hline $\begin{array}{l}\text { Selective reporting (re- } \\
\text { porting bias) }\end{array}$ & Low risk & No problems identified \\
\hline Other bias & High risk & $\begin{array}{l}\text { Funded with support from Diamyd Therapeutics and authorship from a mem- } \\
\text { ber of Diamyd }\end{array}$ \\
\hline
\end{tabular}

Agardh 2009

Methods RANDOMISED CONTROLLED CLINICAL TRIAL (RCT): yes, parallel RCT

RANDOMISATION RATIO: equal ratio to four groups

NON-INFERIORITY DESIGN: no

EQUIVALENCE DESIGN: no

ETHICS APPROVAL OBTAINED: yes

PATIENT CONSENT OBTAINED: yes

BLINDING OF PATIENT (P), EDUCATOR (E), RESEARCHER (R): $P=$ yes, E = yes, $R=$ unclear

ANALYSIS BY INTENTION TO TREAT: no, exploratory trial. However, manuscript states "the study was carried out according to the intention-to-treat principle"

POWER CALCULATION: no

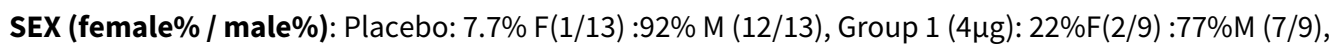
Group $2(20 \mu \mathrm{g}): 25 \% \mathrm{~F}(2 / 8): 75 \% M(6 / 8)$, Group 3 (100 $\mu \mathrm{g}): 33 \% \mathrm{~F}(3 / 9): 66 \% \mathrm{M}(6 / 9)$, Group $4(500 \mu \mathrm{g}): 0 \%$ $\mathrm{F}(0 / 8): 100 \% \mathrm{M}(8 / 8)$ 


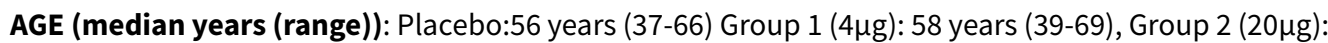
57 years (48-67), Group $3(100 \mu \mathrm{g}): 57$ years (30-69), Group $4(500 \mu \mathrm{g})$ : 53 years (39-62)

ETHNIC GROUPS (\%): not specified

DURATION OF DISEASE (mean years (SD)): Not given

INCLUSION CRITERIA:(1) Male or female aged 30-70 years (2) diagnosed with type 2 diabetes within the previous 5 years (3) presence of GADA (4) only requiring diabetes treatment with diet, oral hypoglycaemic agents, or both (5) females of non-child-bearing potential (6) absence of associated serious diseases or conditions which, in the opinion of the investigator would exclude the patient from the trial (7) patients who had given written informed consent at the screening visit.

EXCLUSION CRITERIA: not specified

DIAGNOSTIC CRITERIA: Diagnosed with type 2 diabetes within the previous 5 years, presence of GADA, only requiring treatment with diet, oral hypoglycaemic agents or both.

CO-MORBIDITIES:Not given

CO-MEDICATIONS: Not given

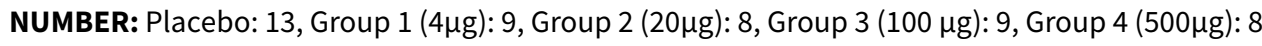

LOSS TO FOLLOW-UP: $14.9 \%(7 / 47)$

Interventions

NUMBER OF STUDY CENTRES:2

COUNTRY/ LOCATION: Sweden

SETTING: out patient

INTERVENTION (ROUTE, TOTAL DOSE/DAY, FREQUENCY): dose comparison of subcutaneous GAD (Diamyd) injections at $4 \mathrm{ug}, 20 \mathrm{ug}, 100 \mathrm{ug}$ or $500 \mathrm{ug}$ doses

CONTROL (ROUTE, TOTAL DOSE/DAY, FREQUENCY): placebo (Alhydrogel)

TREATMENT BEFORE STUDY: All intervention patients received $4 \mu \mathrm{g}$ for 8 weeks. If there were no safety concerns then the higher dose $(20 \mu \mathrm{g}$ or $100 \mu \mathrm{g}$ or $500 \mu \mathrm{g})$ was initiated.

TITRATION PERIOD: No applicable.

Outcomes PRIMARY OUTCOME(S) (as stated in the publication): Not stated but objectives states "evaluate long term clinical safety" Investigate the clinical safety of subcutaneously administered Diamyd

SECONDARY OUTCOMES (as stated in the publication): Not stated but objectives states "evaluate dose level effects on beta cell function".

\section{ADDITIONAL OUTCOMES:}

1. GAD65, 2. IA-2A, IAA, ICAs, 3. BMI, serum creatinine, lipid profile, 4. HbA1c (\%), 5. Fasting blood glucose $(\mathrm{mmol} / \mathrm{L}), 6$. fasting and stimulated C-peptide ( $\mathrm{nmol} / \mathrm{L}), 7$. Adverse events

RUN-IN PERIOD: 8 weeks in the intervention group ( $4 \mu \mathrm{g}$ for 8 weeks before higher dose initiated) - taken from previous publication

\section{Publication details LANGUAGE OF PUBLICATION:English \\ COMMERCIAL FUNDING: yes \\ NON-COMMERCIAL FUNDING: no}


Agardh 2009 (Continued)

PUBLICATION STATUS (PEER REVIEW JOURNAL): yes

PUBLICATION STATUS (JOURNAL SUPPLEMENT): no

PUBLICATION STATUS (ABSTRACT): Full paper

\begin{tabular}{|c|c|c|}
\hline Stated aim for study & \multicolumn{2}{|c|}{ Quote " To evaluate long-term clinical safety and dose level effects on beta cell function" } \\
\hline Notes & \multicolumn{2}{|c|}{ Comment: This study is a follow-up of Agardh 2005} \\
\hline \multicolumn{3}{|l|}{ Risk of bias } \\
\hline Bias & Authors' judgement & Support for judgement \\
\hline $\begin{array}{l}\text { Random sequence genera- } \\
\text { tion (selection bias) }\end{array}$ & Unclear risk & Not stated \\
\hline $\begin{array}{l}\text { Allocation concealment } \\
\text { (selection bias) }\end{array}$ & Low risk & $\begin{array}{l}\text { "Randomisation was concealed by the clinical research organisation monitor- } \\
\text { ing the study without any involvement by study investigators" }\end{array}$ \\
\hline $\begin{array}{l}\text { Blinding (performance } \\
\text { bias and detection bias) } \\
\text { All outcomes }\end{array}$ & Low risk & Participants, health care professionals and researchers blinded. \\
\hline $\begin{array}{l}\text { Incomplete outcome data } \\
\text { (attrition bias) } \\
\text { All outcomes }\end{array}$ & Low risk & Loss to follow-up of $15 \%$ of participants \\
\hline $\begin{array}{l}\text { Selective reporting (re- } \\
\text { porting bias) }\end{array}$ & Low risk & No problem identified \\
\hline Other bias & High risk & Funded with support from Diamyd Therapueutics \\
\hline
\end{tabular}

Cabrera-Rode 2002

RANDOMISED CONTROLLED CLINICAL TRIAL (RCT): yes, parallel RCT
RANDOMISATION RATIO: equal ratio assumed (not stated in manuscript)
NON-INFERIORITY DESIGN: no
EQUIVALENCE DESIGN: no
ETHICS APPROVAL OBTAINED: unclear (not stated)
PATIENT CONSENT OBTAINED: yes
BLINDING OF PATIENT (P), EDUCATOR (E), RESEARCHER (R): P= no, E = no, R= no
ANALYSIS BY INTENTION TO TREAT: not stated. No loss to follow-up
POWER CALCULATION: no
WHO PARTCIPATED:
SEX (female\% / male\%): Insulin+SU: $66 \% \mathrm{~F}(4 / 6): .33 \%$ M (2/6). Insulin: $38 \% \mathrm{~F}(3 / 8): 62 \% M(5 / 8)$
AGE (mean years (SD)): Insulin+SU: 53.5 (16.9), Insulin: 53.0 (6.4)
ETHNIC GROUPS (\%): not specified


DURATION OF DISEASE (mean years (SD)):Insulin + SU: 1.5 yrs (1.8), Insulin: 2.0 yrs (2.6)

INCLUSION CRITERIA: Type 2 diabetic patients with ICA (>20 JDF U) and GADA65A (on at least two consecutive tests) previously treated with glibenclamide and insulin (for at least 1 month) without history of ketonuria and diabetic ketoacidosis.

EXCLUSION CRITERIA: not specified

DIAGNOSTIC CRITERIA: Diagnosed with type 2 diabetes with ICA and GADA

CO-MORBIDITIES:Not given

CO-MEDICATIONS: Not given

NUMBER: Insulin + SU: 6, Insulin: 8

LOSS TO FOLLOW-UP: $0 \%$

Interventions

NUMBER OF STUDY CENTRES: not given

COUNTRY/LOCATION: CUBa

SETTING: out patient

INTERVENTION (ROUTE, TOTAL DOSE/DAY, FREQUENCY): insulin therapy

CONTROL (ROUTE, TOTAL DOSE/DAY, FREQUENCY): insulin therapy plus sulphonylurea (glibenclamide)

TREATMENT BEFORE STUDY: Previously treated with glibenclamide and insulin (for at least 1 month)

TITRATION PERIOD: Not given

Outcomes

PRIMARY OUTCOME(S) (as stated in the publication): Not stated but objectives states "evaluate if exclusion of glibenclamide may diminish levels of ICA and anti GADA65 antibodies"

SECONDARY OUTCOMES (as stated in the publication): Not stated but objectives states "evaluate if exclusion of glibenclamide may improve fasting glucose and insulin secretion".

\section{ADDITIONAL OUTCOMES:}

Collected at baseline and 12 months : 1 . Fasting blood glucose (mmol/L), 2. Fasting C-peptide (pmol/L), 3. BMI (kg/m2), 4. Insulin dose (U/day), 5. SU (glibenclamide, mg/day)

DURATION OF FOLLOW-UP: 12 months

RUN-IN PERIOD: Treatment with glibenclamide and insulin for at least 1 month

PAiblication details
COMMERCIAL FUNDING: no
NON-COMMERCIAL FUNDING: yes
PUBLICATION STATUS (PEER REVIEW JOURNAL): yes
PUBLICATION STATUS (JOURNAL SUPPLEMENT): no
PUBLICATION STATUS (ABSTRACT): Full paper


Cabrera-Rode 2002 (Continued)

Stated aim for study

Quote "to evaluate whether the exclusion of glibenclamide in the treatment of ICA positive type 2 diabetic patients may diminish the levels of ICA and anti-GAD65 autoantibodies as well as improve fasting glucose and insulin secretion "

\section{Notes}

\section{Risk of bias}

\begin{tabular}{|c|c|c|}
\hline Bias & Authors' judgement & Support for judgement \\
\hline $\begin{array}{l}\text { Random sequence genera- } \\
\text { tion (selection bias) }\end{array}$ & Unclear risk & No description given \\
\hline $\begin{array}{l}\text { Allocation concealment } \\
\text { (selection bias) }\end{array}$ & Low risk & Unblinded \\
\hline $\begin{array}{l}\text { Blinding (performance } \\
\text { bias and detection bias) } \\
\text { All outcomes }\end{array}$ & Unclear risk & Unblinded trial but there was no evidence that the analyst was blinded \\
\hline $\begin{array}{l}\text { Incomplete outcome data } \\
\text { (attrition bias) } \\
\text { All outcomes }\end{array}$ & Low risk & No participants lost to follow-up \\
\hline $\begin{array}{l}\text { Selective reporting (re- } \\
\text { porting bias) }\end{array}$ & Low risk & HbA1c was not reported however FBG was reported \\
\hline Other bias & Low risk & No problem identified \\
\hline
\end{tabular}

Davis 2005

RANDOMISED CONTROLLED CLINICAL TRIAL (RCT): yes, parallel RCT
RANDOMISATION RATIO: equal ratio assumed (not stated in manuscript)
NON-INFERIORITY DESIGN: no
EQUIVALENCE DESIGN: no
ETHICS APPROVAL OBTAINED: yes
PATIENT CONSENT OBTAINED: yes
BLINDING OF PATIENT (P), EDUCATOR (E), RESEARCHER (R): P= no, E = no, R= unclear
ANALYSIS BY INTENTION TO TREAT: Yes
POWER CALCULATION: no
WHO PARTCIPATED:
SEX (female\% / male\%): unable to distinguish by treatment groups. Of total antibody positive group
56\% ( $=293 / 536)$ were male
AGE (mean years (SD)): unable to distinguish by treatment groups. Of total antibody positive group,
average age 48.2 (SD: 10.8 )
ETHNIC GROUPS (\%): unable to distinguish by treatment groups. Of total antibody positive group; WC
(initials not explained in text so assumed white Caucasian): $93 \%$, AC (initials not explained in text but


DURATION OF DISEASE (mean years (SD)): Newly diagnosed. Average disease duration not stated

INCLUSION CRITERIA: aged 25-65 years with type 2 diabetes and fasting plasma glucose above 6.0 $\mathrm{mmol} / \mathrm{L}$ on two subsequent occasions.

EXCLUSION CRITERIA: Exclusion criteria (1) severe vasculare disease, (2) accelerated hypertension (3) proliferative retinopathy (4) renal failure (5) other life threatening disease (6) illness requiring systemic steroids (7) occupation precluding insulin treatment (8) unable to speak English (9) ketonuria greater than $3 \mathrm{mmol} / /$ suggestive of type 1 diabetes.

DIAGNOSTIC CRITERIA: Type 2 diabetes newly diagnosed by general practitioner and fasting plasma glucose higher than $6.0 \mathrm{mmol} / \mathrm{L}$ on two subsequent occasions.

CO-MORBIDITIES:Not given

CO-MEDICATIONS: Not given

NUMBER: Group FPG 60.-14.9 mmol/L : insulin: 95, SU: 140, Conventional: 100

Group FPG>15 mmol/L : insulin 65, SU 88.

LOSS TO FOLLOW-UP: not given

Interventions

NUMBER OF STUDY CENTRES:23 centres

COUNTRY/ LOCATION: UK

SETTING: general practitioner/out-patients

INTERVENTION (ROUTE, TOTAL DOSE/DAY, FREQUENCY): Baseline FPG 6.0-14 mmol/L: Insulin OR SU. Baseline FPG>15 mmol/L: Insulin

CONTROL (ROUTE, TOTAL DOSE/DAY, FREQUENCY): Baseline FPG 6.0-14 mmol/L. Conventional care. Baseline FPG $>15 \mathrm{mmol} / \mathrm{L}$ : SU.

TREATMENT BEFORE STUDY: All patients entered a 3-4 month dietary run-in period, during which they were advised to take a diet containing $50 \%$ carbohydrate, with low saturated fat, high fibre.

TITRATION PERIOD: None

Outcomes PRIMARY OUTCOME(S) (as stated in the publication): Not stated but objectives states "examine the effect of autoantibody status on glycaemic response to therapy"

SECONDARY OUTCOMES (as stated in the publication): Not stated but objectives states "assess the association between autoantibody status and cardiovascular risk".

ADDITIONAL OUTCOMES: Recorded annually: HbA1c, weight

Study details DURATION OF INTERVENTION: 10 years

DURATION OF FOLLOW-UP: 10 years

RUN-IN PERIOD: 3- 4 months

Publication details

LANGUAGE OF PUBLICATION: English

COMMERCIAL FUNDING: yes

NON-COMMERCIAL FUNDING: yes

PUBLICATION STATUS (PEER REVIEW JOURNAL): yes 
Davis 2005 (Continued)

PUBLICATION STATUS (JOURNAL SUPPLEMENT): no

PUBLICATION STATUS (ABSTRACT): Full paper

Stated aim for study

Quote "to examine objectively the effect of autoantibody status on glycaemic response to therapy and to assess the association between autoantibody status and cardiovascular risk "

\section{Notes}

\section{Risk of bias}

\begin{tabular}{lll}
\hline Bias & Authors' judgement & Support for judgement \\
\hline $\begin{array}{l}\text { Random sequence genera- } \\
\text { tion (selection bias) }\end{array}$ & Unclear risk & Not described \\
\hline $\begin{array}{l}\text { Allocation concealment } \\
\text { (selection bias) }\end{array}$ & Low risk & Unblinded \\
\hline $\begin{array}{l}\text { Blinding (performance } \\
\text { bias and detection bias) }\end{array}$ & Unclear risk & Unblinded but there was no evidence that the analyst was blinded \\
$\begin{array}{l}\text { All outcomes } \\
\begin{array}{l}\text { Incomplete outcome data } \\
\text { (attrition bias) } \\
\text { All outcomes }\end{array}\end{array}$ & High risk & Not described (i.e. loss to follow-up) \\
\hline $\begin{array}{l}\text { Selective reporting (re- } \\
\text { porting bias) }\end{array}$ & High risk & No record of mortality, C-peptide or intention to treat analysis \\
\hline \begin{tabular}{l} 
Other bias \\
\hline
\end{tabular} & High risk & Commercial sponsorship gives potential for bias \\
\hline
\end{tabular}

\section{Kobayashi 1996}

RANDOMISED CONTROLLED CLINICAL TRIAL (RCT): yes, parallel RCT
RANDOMISATION RATIO: equal ratio
NON-INFERIORITY DESIGN: no
EQUIVALENCE DESIGN: no
ETHICS APPROVAL OBTAINED: unclear
PATIENT CONSENT OBTAINED: yes
BLINDING OF PATIENT (P), EDUCATOR (E), RESEARCHER (R): P= no, E = no, R= unclear
ANALYSIS BY INTENTION TO TREAT: no (not stated in manuscript)
POWER CALCULATION: no
WHO PARTCIPATED:
SEX (female\% / male $\%):$ Insulin $30 \% \mathrm{~F}(2 / 5): 60 \% \mathrm{M}(3 / 5), \mathrm{SU} 30 \% \mathrm{~F}(2 / 5): 60 \% \mathrm{M}(3 / 5)$
AGE (mean years (SD)): Insulin: 51 years (8), SU 48 yrs (11)
ETHNIC GROUPS (\%): not stated


DURATION OF DISEASE (mean years (SD)): insulin 0.7 yrs (1.1), SU 1.5 yrs (2.1)

INCLUSION CRITERIA: (1) disease diagnosed according to the National Diabetes Data Group (2) ICA positive (3) patients were not related to each other

EXCLUSION CRITERIA: (1) history of ketonuria, diabetic ketoacidosis or marked hypoglycaemia initially requiring insulin

DIAGNOSTIC CRITERIA: Type 2 diabetes newly diagnosed by general practitioner and fasting plasma glucose higher than $6.0 \mathrm{mmol} / \mathrm{L}$ on two subsequent occasions.

CO-MORBIDITIES:Not given

CO-MEDICATIONS: Not given

NUMBER: Insulin 5, SU 5.

LOSS TO FOLLOW-UP: $0 \%$

Interventions

NUMBER OF STUDY CENTRES: not given

COUNTRY/ LOCATION: Japan

SETTING: out-patient

INTERVENTION (ROUTE, TOTAL DOSE/DAY, FREQUENCY): small doses of sub-cutaneous insulin

CONTROL (ROUTE, TOTAL DOSE/DAY, FREQUENCY): sulphonylurea (glibenclamide)

TREATMENT BEFORE STUDY:Diet therapy before study entry. Consume a diet containing $30 \mathrm{kcal}$ per kg ideal body weight per day with 55\%-60\% carbohydrate.

TITRATION PERIOD:None

Outcomes PRIMARY OUTCOME(S) (as stated in the publication): Not stated but objectives states "effects of small doses of insulin in patients with NIDDM who were ICA positive"

SECONDARY OUTCOMES (as stated in the publication): Not stated

\section{ADDITIONAL OUTCOMES:}

Collected at baseline and 30 months.

1. HbA1c (\%), 2. Fasting blood glucose (mmol/L) 3. Change in serum C-peptide to OGTT 4.. 2-hr blood glucose (mmol/L), 5. BMI (kg/m2), 5. Insulin dose (U/day), 6. ICA titre.

\begin{tabular}{ll}
\hline Study details & DURATION OF INTERVENTION: 30 months \\
& DURATION OF FOLLOW-UP: 30 months \\
& RUN-IN PERIOD: Not given \\
\hline Publication details & LANGUAGE OF PUBLICATION: English \\
COMMERCIAL FUNDING: no \\
NON-COMMERCIAL FUNDING: yes \\
PUBLICATION STATUS (PEER REVIEW JOURNAL): yes \\
PUBLICATION STATUS (JOURNAL SUPPLEMENT):no \\
PUBLICATION STATUS (ABSTRACT): Full paper
\end{tabular}


Kobayashi 1996 (Continued)

Stated aim for study

Quote " conduct a prospective pilot study on the effects of small doses of insulin in patients with presumed NIDDM who were ICA and thus at high risk for progression to insulin dependence"

Notes

\section{Risk of bias}

\begin{tabular}{|c|c|c|}
\hline Bias & Authors' judgement & Support for judgement \\
\hline $\begin{array}{l}\text { Random sequence genera- } \\
\text { tion (selection bias) }\end{array}$ & Unclear risk & Not given in manuscript \\
\hline $\begin{array}{l}\text { Allocation concealment } \\
\text { (selection bias) }\end{array}$ & Low risk & Unblinded \\
\hline $\begin{array}{l}\text { Blinding (performance } \\
\text { bias and detection bias) } \\
\text { All outcomes }\end{array}$ & Unclear risk & Unblinded but there was no evidence that the analyst was blinded \\
\hline $\begin{array}{l}\text { Incomplete outcome data } \\
\text { (attrition bias) } \\
\text { All outcomes }\end{array}$ & Low risk & No problems identified \\
\hline $\begin{array}{l}\text { Selective reporting (re- } \\
\text { porting bias) }\end{array}$ & Low risk & No problems identified \\
\hline Other bias & Low risk & No problems identified \\
\hline
\end{tabular}

L-Hallin 1999

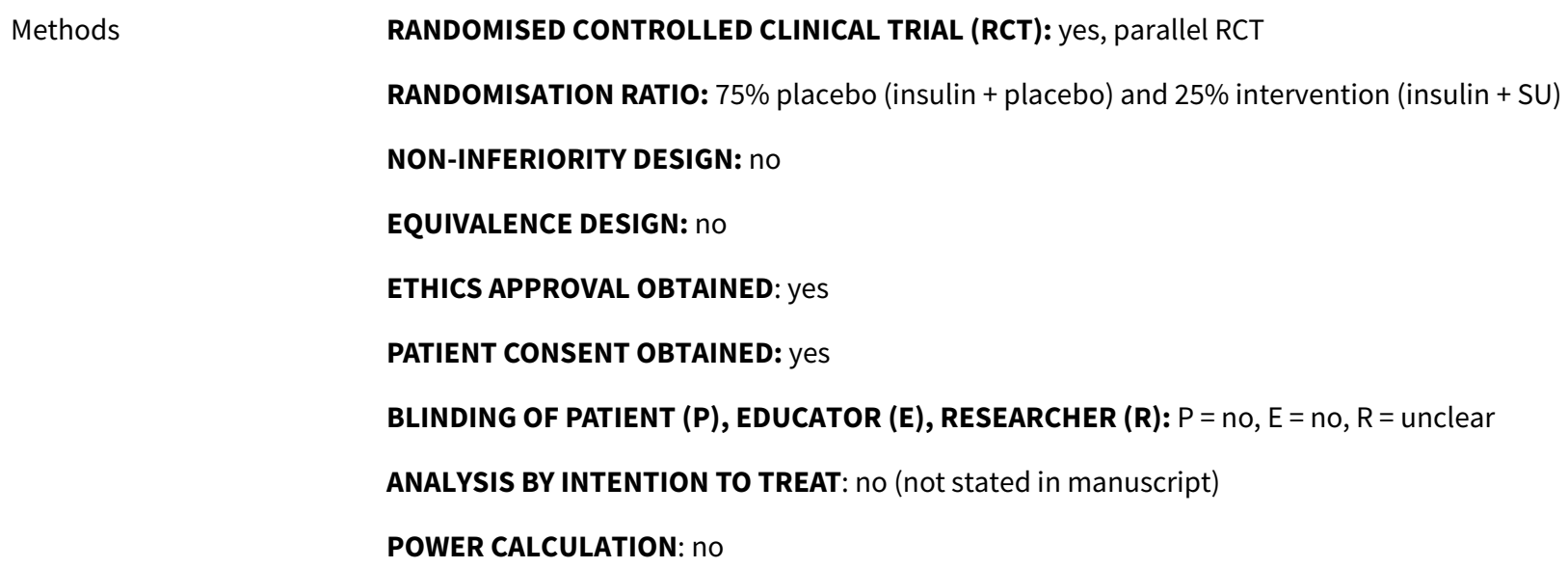

SEX (female\% / male\%):Placebo (insulin + placebo): 58\% F (7/12), 48\% M (5/12), SU (insulin+SU) 0\% F $(0 / 3), 100 \% \mathrm{M}(3 / 3)$

AGE (mean years (SD)): Placebo (insulin+ placebo) $56.4 \mathrm{yrs,} \mathrm{SU} \mathrm{(insulin+} \mathrm{SU):} 60 \mathrm{yrs}$

ETHNIC GROUPS (\%): not specified

DURATION OF DISEASE (mean years (SD)): not reported for antibody positive patients only 
INCLUSION CRITERIA: (1) type 2 diabetic patients (the findings from the study's 15 GAD positive patients were of relevance to this review) (2) $35-75$ years old (3) BMI $22-32 \mathrm{~kg} / \mathrm{m} 2$ (4) previous successful response to sulphonylurea (5) fasting blood glucose $>8 \mathrm{mmol} / \mathrm{L}$ and/or a postprandial blood glucose $>11 \mathrm{mmol} / \mathrm{L}$ and/or an $\mathrm{HbAlc}>3 \%$ above normal per local standard, despite treatment with maximal doses of SU for at least 3 months

EXCLUSION CRITERIA: (1) renal disease (2) liver dysfunction (3) concurrent acute disease

DIAGNOSTIC CRITERIA:Type 2 diabetes GAD antibodies

CO-MORBIDITIES:Not given

CO-MEDICATIONS: Not given

NUMBER: Placebo (insulin+placebo) 12, SU (insulin + SU) 3

LOSS TO FOLLOW-UP: $13.3 \%(2 / 15)$

Interventions

NUMBER OF STUDY CENTRES:9

COUNTRY/ LOCATION: Sweden

SETTING: out-patient

INTERVENTION (ROUTE, TOTAL DOSE/DAY, FREQUENCY): Sulphonylurea (glibenclamide) and premix insulin for 8 months

CONTROL (ROUTE, TOTAL DOSE/DAY, FREQUENCY): Sulphonylurea (glibenclamide) and premix insulin for 4 months, then premix insulin alone for 4 months

TREATMENT BEFORE STUDY:Run-in period for 1-2 weeks, SU treatment was standardized to $10.5 \mathrm{mg}$ glibenclamide daily. Then 4 months on premixed insulin in combination with open glibenclamide.

TITRATION PERIOD: The insulin dose was increased every 2-4 weeks during the first three months to achieve satisfactory metabolic control

Outcomes

PRIMARY OUTCOME(S) (as stated in the publication): Not stated but objectives states "identifying responders to combined glibenclamide and insulin treatment and predictors of such response, in patients no longer able to achieve acceptable metabolic control with SU alone"

SECONDARY OUTCOMES (as stated in the publication): Not stated

ADDITIONAL OUTCOMES:

Collected at baseline, 4 and 8 months.

1. Fasting blood glucose (mmol/L), 2. HbAlc (\%), 3. Fasting C-peptide (nmol/L), 4. Free P-insulin (mU/

L), 5. KITT (\%/min), 6. Weight (kg)

Study details

DURATION OF INTERVENTION: 8 months in total

DURATION OF FOLLOW-UP: 8 months

RUN-IN PERIOD:4 months

Publication details
COMMERCIAL FUNDING: yes
NON-COMMERCIAL FUNDING: yes
PUBLICATION STATUS (PEER REVIEW JOURNAL): yes
PUBLICATION STATUS (JOURNAL SUPPLEMENT): no


L-Hallin 1999 (Continued)

PUBLICATION STATUS (ABSTRACT): Full paper

Stated aim for study Quote "Identifying responders to combined glibenclamide and insulin treatment and predictors of such response, in patients no longer able to achieve acceptable metabolic control "

\section{Notes}

\section{Risk of bias}

\begin{tabular}{|c|c|c|}
\hline Bias & Authors' judgement & Support for judgement \\
\hline $\begin{array}{l}\text { Random sequence genera- } \\
\text { tion (selection bias) }\end{array}$ & Unclear risk & Not described \\
\hline $\begin{array}{l}\text { Allocation concealment } \\
\text { (selection bias) }\end{array}$ & Low risk & Unblinded \\
\hline $\begin{array}{l}\text { Blinding (performance } \\
\text { bias and detection bias) } \\
\text { All outcomes }\end{array}$ & Unclear risk & Unblinded but there was no evidence that the analyst was blinded \\
\hline $\begin{array}{l}\text { Incomplete outcome data } \\
\text { (attrition bias) } \\
\text { All outcomes }\end{array}$ & Low risk & No problem identified \\
\hline $\begin{array}{l}\text { Selective reporting (re- } \\
\text { porting bias) }\end{array}$ & Low risk & No problems identified \\
\hline Other bias & High risk & Commerical funding from Aventis \\
\hline
\end{tabular}

RANDOMISED CONTROLLED CLINICAL TRIAL (RCT): yes, parallel RCT
RANDOMISATION RATIO: equal ratio assumed (not stated in manuscript)
NON-INFERIORITY DESIGN: no
EQUIVALENCE DESIGN: no
ETHICS APPROVAL OBTAINED: yes
PATIENT CONSENT OBTAINED: yes
BLINDING OF PATIENT (P), EDUCATOR (E), RESEARCHER (R): P = no, E = no, R= unclear
ANALYSIS BY INTENTION TO TREAT: no, ITT not reported in the paper
POWER CALCULATION: no
WHO PARTCIPATED:
SEX (female\% / male $\%):$ Insulin $27 \% \mathrm{~F}(5 / 18): 72 \% \mathrm{M}(13 / 18)$, Insulin+Vit D $17.6 \% \mathrm{~F}(3 / 17): 82.4 \%$
M(14/17)
AGE (mean years (SD)): Insulin: 42.8 years (12.9), Insulin+Vit D 38.5 yrs (12.5)
ETHNIC GROUPS (\%): not stated


INCLUSION CRITERIA: (1) age to onset over 20 years (2) no ketosis within the first 6 months after diagnosis (3) disease duration less than 5 years (4) autoantibodies to GADA positive twice within one month and (5) fasting C-peptide (FCP) $>200 \mathrm{pmol} / \mathrm{L}$ at entry.

EXCLUSION CRITERIA: (1) patients with liver or kidney disorders (alanine aminotransferase or aspartate aminotransferase $>2.5$-fold of upper normal limit, total bilirubin $>1.5 \mathrm{U} / \mathrm{mL}$ or blood creatinine $>$ $15 \mathrm{mg} / \mathrm{dL}$ (2) premenopausal women who did not use effective contraception, or any pregnant women (3) patients who have had any severe systemic disease such as heart failure, cancer, stroke, or recent surgery.

DIAGNOSTIC CRITERIA: Diabetes diagnosed according to American Diabetes Association (ADA) standards

CO-MORBIDITIES:Not given

CO-MEDICATIONS: Not given

NUMBER: Insulin 18, Insulin+Vit D 17

LOSS TO FOLLOW-UP: 0\%

Interventions NUMBER OF STUDY CENTRES: not given

COUNTRY/LOCATION: China

SETTING: not given

INTERVENTION (ROUTE, TOTAL DOSE/DAY, FREQUENCY): both groups treated with mixed human Insulin (Novolin 30 R or Humulin 70/30). Vit D group was Alpha-calcidol 0.25 ug bid for 12 months glibenclamide) and premix insulin for 8 months

CONTROL (ROUTE, TOTAL DOSE/DAY, FREQUENCY): both groups treated with mixed human Insulin (Novolin 30 R or Humulin 70/30).

TREATMENT BEFORE STUDY:None

TITRATION PERIOD:None

Outcomes

PRIMARY OUTCOME(S) (as stated in the publication): Not stated but objectives states "possible benefits of 1-a-hycroxyvitamin C3 combined with insulin on beta-cell function"

SECONDARY OUTCOMES (as stated in the publication): Not stated

ADDITIONAL OUTCOMES:

Collected at baseline and 12 months.

1. Fasting C-peptide 2. 2-h postprandial C-peptide (PCP)

Study details

DURATION OF INTERVENTION: 12 months

DURATION OF FOLLOW-UP: 12 months

RUN-IN PERIOD: none

Publication details

LANGUAGE OF PUBLICATION: English

COMMERCIAL FUNDING: no

NON-COMMERCIAL FUNDING: yes

PUBLICATION STATUS (PEER REVIEW JOURNAL): yes

PUBLICATION STATUS (JOURNAL SUPPLEMENT):no 
Li 2009 (Continued)

PUBLICATION STATUS (ABSTRACT): Full paper

Stated aim for study

Quote " to study the possible benefits of 1-a-hydroxyvitamin D3 combined with insulin on $\beta$-cell function in LADA"

\section{Notes}

\section{Risk of bias}

\begin{tabular}{|c|c|c|}
\hline Bias & Authors' judgement & Support for judgement \\
\hline $\begin{array}{l}\text { Random sequence genera- } \\
\text { tion (selection bias) }\end{array}$ & Unclear risk & Not described \\
\hline $\begin{array}{l}\text { Allocation concealment } \\
\text { (selection bias) }\end{array}$ & Low risk & Unblinded \\
\hline $\begin{array}{l}\text { Blinding (performance } \\
\text { bias and detection bias) } \\
\text { All outcomes }\end{array}$ & Unclear risk & Unblinded but there was no evidence that the analyst was blinded \\
\hline $\begin{array}{l}\text { Incomplete outcome data } \\
\text { (attrition bias) } \\
\text { All outcomes }\end{array}$ & Low risk & No problems identified \\
\hline $\begin{array}{l}\text { Selective reporting (re- } \\
\text { porting bias) }\end{array}$ & High risk & HbA1c was not reported \\
\hline Other bias & Low risk & No problems identified \\
\hline
\end{tabular}

Maruyama 2003

RANDOMISED CONTROLLED CLINICAL TRIAL (RCT): yes, parallel
RANDOMISATION RATIO: equal ratio assumed (not stated in manuscript)
NON-INFERIORITY DESIGN: no
EQUIVALENCE DESIGN: no
ETHICS APPROVAL OBTAINED: unclear
PATIENT CONSENT OBTAINED: unclear
BLINDING OF PATIENT (P), EDUCATOR (E), RESEARCHER (R): P=no, E = no, R= unclear
ANALYSIS BY INTENTION TO TREAT: No, not stated in the manuscript
POWER CALCULATION: no
WHO PARTCIPATED:
SEX (female\% / male\%): Insulin $37.5 \% \mathrm{~F}(9 / 24): 62.5 \% \mathrm{M}(15 / 24)$, SU $53 \% \mathrm{~F}(16 / 30): 47 \% \mathrm{M}(14 / 30)$
AGE (mean years (SD)): Insulin: 56.6 years (13.4), SU 50.4 yrs (14.1)
ETHNIC GROUPS (\%): not stated
DURATION OF DISEASE (mean years (SD)): insulin 2.7 yrs (3.8), SU 2.4 yrs $(2.9)$


INCLUSION CRITERIA: (1) diagnosis of diabetes according to ADA criteria (2) not treated with insulin at least 6 months after diagnosis of diabetes (3) positive GADA in 2 samples taken within 2 months (4) disease duration $<10$ years (5) patients were unrelated

EXCLUSION CRITERIA: (1) history of ketonuria, diabetic ketoacidosis, marked hyperglycaemia requiring insulin, (2) renal or hepatic dysfunction affecting C-peptide clearance and glucose tolerance,

DIAGNOSTIC CRITERIA: Diabetes diagnosed according to American Diabetes Association (ADA) standards

CO-MORBIDITIES:Not given

CO-MEDICATIONS: Not given

NUMBER: Insulin 24, SU 30

LOSS TO FOLLOW-UP: unclear 54 reported at baseline but 56 reported at 48 months. Assumed typo and 54 participants with no loss of follow-up.

COUNTRY/ LOCATION: Japan

SETTING: out-patient

INTERVENTION (ROUTE, TOTAL DOSE/DAY, FREQUENCY): subcutaneous insulin therapy

CONTROL (ROUTE, TOTAL DOSE/DAY, FREQUENCY): sulphonylurea (glibenclamide)

TREATMENT BEFORE STUDY:None

TITRATION PERIOD: None

Outcomes

PRIMARY OUTCOME(S) (as stated in the publication): Not stated but objectives states "to clarify the frequency of GADA positive patients with non insulin requiring diabetes"

SECONDARY OUTCOMES (as stated in the publication): Not stated but objectives states "to clarify the natural course of these GADA positive patients and to know the preventive effect of insulin on progressive beta cell failure"

\section{ADDITIONAL OUTCOMES:}

Collected at baseline and 4 years.

1. Stimulated C-peptide and change in C-peptide response (ng/ml), 2. Blood glucose, 3. HbA1c (\%), 4. $\operatorname{GADA}(\mathrm{U} / \mathrm{ml})$

Study details

DURATION OF INTERVENTION: 4 yearS

DURATION OF FOLLOW-UP: 4 years (with 3-monthly assessments)

RUN-IN PERIOD: None

Publication details

LANGUAGE OF PUBLICATION: English

COMMERCIAL FUNDING: not reported

NON-COMMERCIAL FUNDING: not reported

PUBLICATION STATUS (PEER REVIEW JOURNAL): yes

PUBLICATION STATUS (JOURNAL SUPPLEMENT): no

PUBLICATION STATUS (ABSTRACT): Full paper 
Maruyama 2003 (Continued)

Stated aim for study

Quote "to clarify the efficacy of small dose of insulin for progressive beta cell failure "

Notes

\section{Risk of bias}

\begin{tabular}{lll}
\hline Bias & Authors' judgement & Support for judgement \\
\hline $\begin{array}{l}\text { Random sequence genera- } \\
\text { tion (selection bias) }\end{array}$ & Unclear risk & Not described \\
\hline $\begin{array}{l}\text { Allocation concealment } \\
\text { (selection bias) }\end{array}$ & Low risk & Unblinded \\
\hline $\begin{array}{l}\text { Blinding (performance } \\
\text { bias and detection bias) } \\
\text { All outcomes }\end{array}$ & Unclear risk & Unblinded but there was no evidence that the analyst was blinded \\
\hline $\begin{array}{l}\text { Incomplete outcome data } \\
\text { (attrition bias) } \\
\text { All outcomes }\end{array}$ & Low risk & $\begin{array}{l}\text { No problems identified (typo suspected on number of patients completing tri- } \\
\text { al) }\end{array}$ \\
\hline $\begin{array}{l}\text { Selective reporting (re- } \\
\text { porting bias) }\end{array}$ & Low risk & No problems identified \\
\hline \begin{tabular}{l} 
Other bias \\
\hline
\end{tabular} & Unclear risk & Sponsorship not reported \\
\hline
\end{tabular}

Maruyama 2008

Methods

RANDOMISED CONTROLLED CLINICAL TRIAL (RCT): yes, parallel RCT

RANDOMISATION RATIO: equal ratio assumed (not stated in manuscript)

NON-INFERIORITY DESIGN: no

EQUIVALENCE DESIGN: no

ETHICS APPROVAL OBTAINED: yes

PATIENT CONSENT OBTAINED: yes

BLINDING OF PATIENT (P), EDUCATOR (E), RESEARCHER (R): $P=$ no, $E=$ no, $R=$ unclear

ANALYSIS BY INTENTION TO TREAT: No, not stated in the manuscript

POWER CALCULATION: YeS

Participants

WHO PARTCIPATED:

SEX (female\% / male\%): Insulin 43\%F (13/30): 57\% M (17/30), SU 46\% F (14/30) : 53\% M(16/30)

AGE (mean years (SD)): Insulin: 54 years (13), SU 51 yrs (13)

ETHNIC GROUPS (\%): not stated

DURATION OF DISEASE (mean years (SD)): insulin 1.7 yrs (1.9), SU 1.9 yrs (1.7) 
INCLUSION CRITERIA: (1) diagnosis of diabetes according to ADA criteria (2) not treated with insulin at least 6 months after diagnosis of diabetes (3) positive GADA in 2 samples taken within 2 months (4) disease duration $<10$ years (5) patients were unrelated

EXCLUSION CRITERIA: (1) history of ketonuria, diabetic ketoacidosis, marked hyperglycaemia requiring insulin, (2) renal or hepatic dysfunction affecting C-peptide clearance and glucose tolerance,

DIAGNOSTIC CRITERIA: Diabetes diagnosed according to American Diabetes Association (ADA) standards

CO-MORBIDITIES:Not given

CO-MEDICATIONS: Not given

NUMBER: Insulin 30, SU 30

LOSS TO FOLLOW-UP: 0\%

NUMBER OF STUDY CENTRES:7
COUNTRY/ LOCATION: Japan
SETTING: Out-patient
INTERVENTION (ROUTE, TOTAL DOSE/DAY, FREQUENCY): subcutaneous insulin therapy
CONTROL (ROUTE, TOTAL DOSE/DAY, FREQUENCY): sulphonylurea (glibenclamide)
TREATMENT BEFORE STUDY:None
TITRATION PERIOD: None.

PRIMARY OUTCOME(S) (as stated in the publication): Not stated but objectives states "to examine
the ability of insulin to prevent progressive beta-cell dysfunction in SPIDDM"
SECONDARY OUTCOMES (as stated in the publication):Not stated
ADDITIONAL OUTCOMES:
Collected at baseline and 4 years.
1. Stimulated C-peptide and change in C-peptide response $(\mathrm{ng} / \mathrm{ml}), 2$. Blood glucose, 3. HbA1c (\%), 4.
GADA $(\mathrm{U} / \mathrm{ml}) 5$. insulin dependent state $6 . \mathrm{BMI}$

Study details

DURATION OF INTERVENTION: 5 yearS

DURATION OF FOLLOW-UP: 5 years (with 3-monthly assessments)

RUN-IN PERIOD: None

\begin{tabular}{ll}
\hline Publication details & LANGUAGE OF PUBLICATION: English \\
COMMERCIAL FUNDING: not reported \\
NON-COMMERCIAL FUNDING: not reported \\
PUBLICATION STATUS (PEER REVIEW JOURNAL): yes \\
PUBLICATION STATUS (JOURNAL SUPPLEMENT): no \\
PUBLICATION STATUS (ABSTRACT): Full paper
\end{tabular}

Stated aim for study

Quote "to examine the ability of insulin to prevent progressive ß-cell dysfunction in SPIDDM " 
Maruyama 2008 (Continued)

Risk of bias

\begin{tabular}{lll}
\hline Bias & Authors' judgement & Support for judgement \\
\hline $\begin{array}{l}\text { Random sequence genera- } \\
\text { tion (selection bias) }\end{array}$ & Low risk & Patients were randomly assigned using a centralized, masked-draw system. \\
\hline $\begin{array}{l}\text { Allocation concealment } \\
\text { (selection bias) }\end{array}$ & Low risk & Unblinded \\
\hline $\begin{array}{l}\text { Blinding (performance } \\
\text { bias and detection bias) } \\
\text { All outcomes }\end{array}$ & Unclear risk & Unblinded but there was no evidence that the analyst was blinded \\
\hline $\begin{array}{l}\text { Incomplete outcome data } \\
\text { (attrition bias) } \\
\text { All outcomes }\end{array}$ & Low risk & No problems identified \\
\hline $\begin{array}{l}\text { Selective reporting (re- } \\
\text { porting bias) }\end{array}$ & Low risk & No problems identified \\
\hline \begin{tabular}{l} 
Other bias \\
\hline
\end{tabular} & Unclear risk & Sponsorship not reported \\
\hline
\end{tabular}

Thunander 2010

Methods RANDOMISED CONTROLLED CLINICAL TRIAL (RCT): Patient preference randomised controlled trial (incomplete randomisation as patients refusing insulin were not analysed within the insulin arm as per ITT but were considered within the tablet arm).

RANDOMISATION RATIO: randomised into two groups in blocks of eight

NON-INFERIORITY DESIGN: no

EQUIVALENCE DESIGN: no

ETHICS APPROVAL OBTAINED: yes

PATIENT CONSENT OBTAINED: yes

BLINDING OF PATIENT (P), EDUCATOR (E), RESEARCHER (R): $P=n o, E=n o, R=$ no

ANALYSIS BY INTENTION TO TREAT: reported to use intention to treat analysis but not evidence this was performed

POWER CALCULATION: no

SEX (female\% / male \%): Conventional treatment group; 42\% F (7/17), 58.8\% M (10/17), insulin group $55 \% \mathrm{~F}(11 / 20), 45 \% \mathrm{M}(9 / 20)$

AGE (mean years (SD)): Conventional treatment group $=57.8 \pm 15.1$, Insulin group $=51.0 \pm 14.3$

ETHNIC GROUPS (\%): not stated

DURATION OF DISEASE (median months (range)):Conventional treatment group $=5.0$ [range 1 to 22], Insulin group $=6.0$ [range: 1.5 to 24$]$ 
INCLUSION CRITERIA: (1) diagnosis of diabetes (2) aged >30 yrs (3) not insulin requiring at diagnosis (3) GAD antibodies or ICA antibodies.

EXCLUSION CRITERIA: (1) mental conditions or severe physical illness.

DIAGNOSTIC CRITERIA: Diagnosed with diabetes with at least one of GADA or ICA

CO-MORBIDITIES:Not given

CO-MEDICATIONS: Not given

NUMBER: Conventional treatment group 17, Insulin 20

LOSS TO FOLLOW-UP:Conventional treatment group $=2$ out of 17 lost at 36 months, Insulin group $=2$ out of 20 lost at 36 months.

COUNTRY/ LOCATION: Sweden

SETTING: out-patient

INTERVENTION (ROUTE, TOTAL DOSE/DAY, FREQUENCY): subcutaneous insulin therapy starting with 2-6 units intermediate-acting insulin at night.

CONTROL (ROUTE, TOTAL DOSE/DAY, FREQUENCY): diet +/- oral hypoglycaemic agents (metformin and or SU)

\section{TREATMENT BEFORE STUDY:None}

TITRATION PERIOD: None.

Outcomes

PRIMARY OUTCOME(S) (as stated in the publication): Not stated but objectives states "to investigate the effect of early insulin treatment of LADA patients on residual beta-cell function compared to a group initially treated with diet and/or oral hypoglycaemic agents"

SECONDARY OUTCOMES (as stated in the publication): Not stated but objectives states "to investigate the effect of early insulin treatment of LADA patients on metabolic control compared to a group initially treated with diet and/or oral hypoglycaemic agents"

\section{ADDITIONAL OUTCOMES:}

Collected at baseline and 12 months, 24 months and 36 months

1.HbA1c, 2. Glucagon-stimulated C-peptide and changes in C-peptide were measured.

\begin{tabular}{ll}
\hline Study details & DURATION OF INTERVENTION:36 months \\
& DURATION OF FOLLOW-UP: 36 months \\
& RUN-IN PERIOD:None \\
\hline Publication details & LANGUAGE OF PUBLICATION: English \\
COMMERCIAL FUNDING: no \\
NON-COMMERCIAL FUNDING: yes \\
PUBLICATION STATUS (PEER REVIEW JOURNAL): yes \\
PUBLICATION STATUS (JOURNAL SUPPLEMENT): no \\
PUBLICATION STATUS (ABSTRACT): full paper
\end{tabular}


Thunander 2010 (Continued)

Stated aim for study

Quote "To investigate the effect of early insulin treatment of LADA patients, during three years, on residual beta-cell function and metabolic control, compared to a group initially treated with diet and/ or hypoglycaemic agents (OHA) "

\section{Notes}

\section{Risk of bias}

\begin{tabular}{|c|c|c|}
\hline Bias & Authors' judgement & Support for judgement \\
\hline $\begin{array}{l}\text { Random sequence genera- } \\
\text { tion (selection bias) }\end{array}$ & Unclear risk & Not described \\
\hline $\begin{array}{l}\text { Allocation concealment } \\
\text { (selection bias) }\end{array}$ & Low risk & $\begin{array}{l}\text { Pre-prepared envelopes were used which is a less robust method compared to } \\
\text { phone or Internet allocation. }\end{array}$ \\
\hline $\begin{array}{l}\text { Blinding (performance } \\
\text { bias and detection bias) } \\
\text { All outcomes }\end{array}$ & Unclear risk & There was no evidence that the analyst was blinded \\
\hline $\begin{array}{l}\text { Incomplete outcome data } \\
\text { (attrition bias) } \\
\text { All outcomes }\end{array}$ & High risk & $\begin{array}{l}\text { Intention to treat was reported but no evidence that it was used. i.e. last re- } \\
\text { sult carried forward for those lost to follow-up, analysis within the insulin arm } \\
\text { of those randomised to insulin but choosing to be treated with conventional } \\
\text { medication. }\end{array}$ \\
\hline $\begin{array}{l}\text { Selective reporting (re- } \\
\text { porting bias) }\end{array}$ & Low risk & No problems identified \\
\hline Other bias & Low risk & No problems identified \\
\hline
\end{tabular}

Xu 2008

Methods RANDOMISED CONTROLLED CLINICAL TRIAL (RCT): yes, parallel RCT

RANDOMISATION RATIO: Equal numbers assumed (not stated in publication)

NON-INFERIORITY DESIGN: no

EQUIVALENCE DESIGN: no

ETHICS APPROVAL OBTAINED: not clear

PATIENT CONSENT OBTAINED: yes

BLINDING OF PATIENT (P), EDUCATOR (E), RESEARCHER (R): $P=n o, E=n o, R=$ no

ANALYSIS BY INTENTION TO TREAT: no, not reported

POWER CALCULATION: no

SEX (female $\%$ / male $\%$ ): TYK and insulin group 38\% $F(14 / 37), 62 \% M(23 / 37)$, insulin group 35\% $\mathrm{F}(13 / 37), 64 \% \mathrm{M}(24 / 37)$

AGE (mean years (SD)): TYK and insulin group $=39.51 \pm 10.6$, Insulin group $=38.7 \pm 8.1$

ETHNIC GROUPS (\%): not stated 
Xu 2008 (Continued)

DURATION OF DISEASE (median months (range)):unclear

INCLUSION CRITERIA: unclear

EXCLUSION CRITERIA:unclear

DIAGNOSTIC CRITERIA: unclear

CO-MORBIDITIES:Not given

CO-MEDICATIONS: Not given

NUMBER: TYK + insulin 37, Insulin 37

LOSS TO FOLLOW-UP: not clear

Interventions

NUMBER OF STUDY CENTRES:1

COUNTRY/ LOCATION: China

SETTING: out-patient

INTERVENTION (ROUTE, TOTAL DOSE/DAY, FREQUENCY): subcutaneous insulin therapy and oral TKY. Insulin injection $0.5 \mathrm{u} / \mathrm{kg}$ daily $2 / 3$ of the amount injected $30 \mathrm{~min}$ before breakfast $1 / 3$ of the amount injected 30min before supper, adjusted according to blood sugar level. TKY consisted of red ginseng $10 \mathrm{~g}$, milkvetch root $30 \mathrm{~g}$, lilyturf root $15 \mathrm{~g}$, wild weed $10 \mathrm{~g}$, coptis root $15 \mathrm{~g}$, cape-jasmine fruit $10 \mathrm{~g}$, giant knotweed rhizome 10g, safflower 10g, and moutain bark 10g.

CONTROL (ROUTE, TOTAL DOSE/DAY, FREQUENCY): subcutaneous insulin therapy (as described above)

TREATMENT BEFORE STUDY:None

TITRATION PERIOD: None.

Outcomes

PRIMARY OUTCOME(S) (as stated in the publication): Not stated but objectives states "to investigate the effect and mechanism of TKY for improving pancreatic islet beta cell function in patients with LADA"

SECONDARY OUTCOMES (as stated in the publication): Not stated

ADDITIONAL OUTCOMES:

1.HbA1c, 2. Stimulated C-peptide and changes in C-peptide were measured 3. Inflammatory markers (IFN-y and IL-4)

Study details

DURATION OF INTERVENTION: 3 months

DURATION OF FOLLOW-UP: 3 months

RUN-IN PERIOD: none

Publication details

LANGUAGE OF PUBLICATION: Chinese

COMMERCIAL FUNDING: no

NON-COMMERCIAL FUNDING: yes

PUBLICATION STATUS (PEER REVIEW JOURNAL): yes

PUBLICATION STATUS (JOURNAL SUPPLEMENT): no

PUBLICATION STATUS (ABSTRACT): Full paper 
Xu 2008 (Continued)

Stated aim for study

Quote " To investigate the effect and mechanism of TYK for improving pancreatic islet $B$ cell function in patients with LADA "

Notes

\section{Risk of bias}

\begin{tabular}{|c|c|c|}
\hline Bias & Authors' judgement & Support for judgement \\
\hline $\begin{array}{l}\text { Random sequence genera- } \\
\text { tion (selection bias) }\end{array}$ & Low risk & Random number table \\
\hline $\begin{array}{l}\text { Allocation concealment } \\
\text { (selection bias) }\end{array}$ & Low risk & Unblinded \\
\hline $\begin{array}{l}\text { Blinding (performance } \\
\text { bias and detection bias) } \\
\text { All outcomes }\end{array}$ & Unclear risk & No evidence the analyst was blinded \\
\hline $\begin{array}{l}\text { Incomplete outcome data } \\
\text { (attrition bias) } \\
\text { All outcomes }\end{array}$ & Unclear risk & Unclear if there were losses to follow-up \\
\hline $\begin{array}{l}\text { Selective reporting (re- } \\
\text { porting bias) }\end{array}$ & Low risk & No problems identified \\
\hline Other bias & Low risk & No problems identified \\
\hline
\end{tabular}

Yang 2009

RANDOMISED CONTROLLED CLINICAL TRIAL (RCT): yes, parallel RCT
RANDOMISATION RATIO: equal ratio assumed (not stated in manuscript)
NON-INFERIORITY DESIGN: no
EQUIVALENCE DESIGN: no
ETHICS APPROVAL OBTAINED: yes
PATIENT CONSENT OBTAINED: yes
BLINDING OF PATIENT (P), EDUCATOR (E), RESEARCHER (R): $P=$ no, E = no, $R=$ no
ANALYSIS BY INTENTION TO TREAT: No
POWER CALCULATION: no

Participants WHO PARTCIPATED:

SEX (female \% / male\%): Insulin group 42\% F(5/12), 58\% M 7/12, Insulin plus rosiglitazone $50 \% \mathrm{~F}$ (6/12), 50\% M (6/12), SU group 43\% F (6/14), 57\% M (8/14), Rosiglitazone group 33\% F(5/15), 66\% M $(10 / 15) 10 \mathrm{M}, 5 \mathrm{~F}$.

AGE (mean years (SD)): Insulin group 48.5 (14.6), Insulin plus rosiglitazone 48.0 (12.8), SU group 50.0 (14.5), Rosiglitazone group 50.6 (11.8)

ETHNIC GROUPS (\%): not stated 
Yang 2009 (Continued)

DURATION OF DISEASE (median months (range)): Insulin 1.35 (1.52), Insulin + rosiglitazone 1.5 (1.52), SU group 1.1 (1.31), Rosiglitazone 1.16 (1.46).

INCLUSION CRITERIA: (1) No ketosis within the first 6 months after diagnosis (2) disease duration less than 5 years (3) FCP level of $0.2 \mathrm{nmol} / \mathrm{L}$ or more (4) diet alone can not achieve glycaemic control.

EXCLUSION CRITERIA: impaired liver, kidney or heart function or other severe diseases.

DIAGNOSTIC CRITERIA: type 2 diabetes diagnosed as LADA

CO-MORBIDITIES:Not given

CO-MEDICATIONS: Not given

NUMBER: Insulin 12, Insulin + rosiglitazone 12, SU 14, Rosiglitazone 15.

LOSS TO FOLLOW-UP: $0 \%$

NUMBER OF STUDY CENTRES:not reported
COUNTRY/ LOCATION: China
SETTING: out-patient
INTERVENTION (ROUTE, TOTAL DOSE/DAY, FREQUENCY): Patients with GADA $<175$ and FCP $>0.3$
nmol/L were randomised to SU. Patinets with GADA $<175 \mathrm{U} / \mathrm{ml}$ and FCP $<0.3 \mathrm{nmol} / \mathrm{L}$ were assigned sub-
cutaneous insulin with rosiglitazone $4 \mathrm{mg} / \mathrm{d}$.
CONTROL (ROUTE, TOTAL DOSE/DAY, FREQUENCY): Patients with GADA $<175$ and FCP $>0.3 \mathrm{nmol} / \mathrm{L}$
were randomised to rosiglitazone $4 \mathrm{mg} / \mathrm{d}$. Patients with GADA $<175 \mathrm{U} / \mathrm{ml}$ and FCP $<0.3 \mathrm{nmol} / \mathrm{L}$ were as-
Signed subcutaneous insulin therapy
TREATMENT BEFORE STUDY:None
TITRATION PERIOD: None.

Outcomes

PRIMARY OUTCOME(S) (as stated in the publication): Not stated but objectives states "to clarify whether LADA benefit from rosiglitazone treatment"

SECONDARY OUTCOMES (as stated in the publication): Not stated

ADDITIONAL OUTCOMES:

1.HbA1C, 2. FBG, 3. Stimulated C-peptide and changes in C-peptide

\begin{tabular}{ll}
\hline Study details & DURATION OF INTERVENTION: 36 months \\
& DURATION OF FOLLOW-UP: 36 months \\
& RUN-IN PERIOD: none \\
\hline Publication details & LANGUAGE OF PUBLICATION: English \\
& COMMERCIAL FUNDING: no \\
& NON-COMMERCIAL FUNDING: yes \\
& PUBLICATION STATUS (PEER REVIEW JOURNAL): yes \\
& PUBLICATION STATUS (JOURNAL SUPPLEMENT): no \\
& PUBLICATION STATUS (ABSTRACT): Full paper \\
\hline Stated aim for study & QUOte "' To clarify whether LADA benefit from rosiglitazone" \\
\hline
\end{tabular}


Yang 2009 (Continued)

Notes

\section{Risk of bias}

\begin{tabular}{|c|c|c|}
\hline Bias & Authors' judgement & Support for judgement \\
\hline $\begin{array}{l}\text { Random sequence genera- } \\
\text { tion (selection bias) }\end{array}$ & Unclear risk & Not described \\
\hline $\begin{array}{l}\text { Allocation concealment } \\
\text { (selection bias) }\end{array}$ & Low risk & Unblinded \\
\hline $\begin{array}{l}\text { Blinding (performance } \\
\text { bias and detection bias) } \\
\text { All outcomes }\end{array}$ & Unclear risk & No evidence the analyst was blinded \\
\hline $\begin{array}{l}\text { Incomplete outcome data } \\
\text { (attrition bias) } \\
\text { All outcomes }\end{array}$ & Low risk & No problems identified \\
\hline $\begin{array}{l}\text { Selective reporting (re- } \\
\text { porting bias) }\end{array}$ & Low risk & No problems identified \\
\hline Other bias & Low risk & No problems identified \\
\hline
\end{tabular}

\section{Zhou 2005}

RANDOMISED CONTROLLED CLINICAL TRIAL (RCT): yes, parallel RCT
RANDOMISATION RATIO: equal ratio assumed (not stated in manuscript)
NON-INFERIORITY DESIGN: no
EQUIVALENCE DESIGN: no
ETHICS APPROVAL OBTAINED: yes
PATIENT CONSENT OBTAINED: yes
BLINDING OF PATIENT (P), EDUCATOR (E), RESEARCHER (R): $P=$ no, E = no, $R=$ no
ANALYSIS BY INTENTION TO TREAT: No
POWER CALCULATION: no

SEX (female\% / male\%): Insulin group 42\% F(5/12), 58\% M 7/12, Insulin plus rosiglitazone 45\% F (5/11), 55\% M (6/11)

AGE (mean years (SD)): Insulin group 51.8 (13.5), Insulin plus rosiglitazone 46.5 (12.2).

ETHNIC GROUPS (\%): not stated

DURATION OF DISEASE (median years $(\mathbf{m i n}-\mathbf{m a x})$ ): Insulin $=0.8(0.3-4.0)$, Insulin + rosiglitazone $=1.8$ (0.1-5.0) 
INCLUSION CRITERIA: (1) diabetes diagnosed according to the report of WHO 1999 (2) age at onset over 25 years old (3) no ketosis within the first six months of diagnosis (4) disease duration less than five years (5) GAD-Ab positive testing twice within one month (6) FCP level of $0.3 \mathrm{nmol} / \mathrm{L}$ or more.

EXCLUSION CRITERIA: impaired liver, kidney or heart function or other severe diseases.

DIAGNOSTIC CRITERIA: diabetes according to the report of WHO 1999 with GAD-Ab positive twice within one month

CO-MORBIDITIES:Not given

CO-MEDICATIONS: Not given

NUMBER: Insulin 12, Insulin + rosiglitazone 11

LOSS TO FOLLOW-UP: 14/22 follow-up to 18 months or $36 \%$ lost to follow-up.

Interventions NUMBER OF STUDY CENTRES:not reported

COUNTRY/ LOCATION: China

SETTING: out-patient

INTERVENTION (ROUTE, TOTAL DOSE/DAY, FREQUENCY): Insulin + rosiglitazone. Premixed human insulin (Novolin $30 \mathrm{R}$ or Humulin 70/30) was injected twice a day. Rosiglitazone $4 \mathrm{mg} / \mathrm{day}$. Diet advice

CONTROL (ROUTE, TOTAL DOSE/DAY, FREQUENCY): Insulin. Premixed human insulin (Novolin 30 R or Humulin 70/30) was injected twice a day. Diet advice

TREATMENT BEFORE STUDY:None

TITRATION PERIOD: None.

Outcomes

PRIMARY OUTCOME(S) (as stated in the publication): Not stated but objectives states "we hypothesized that thiazolidinediones combined with insulin in LADA may have and additional benefit on islet beta cell function"

SECONDARY OUTCOMES (as stated in the publication): Not stated

ADDITIONAL OUTCOMES:

Collected at baseline, 612 and 18 months.

1. Fasting C-peptide (nmol/L), 2. Insulin dose (U/day), 3. HbA1c (\%), 4. Fasting C-peptide (nmol/L), 5. Cpeptide after $2 \mathrm{~h} 75-\mathrm{g}$ glucose load (nmol/L).

Study details DURATION OF INTERVENTION: 18 months

DURATION OF FOLLOW-UP: 18 months. All 23 patients followed-up for 6 months, but only 17 for 12 months and 14 for 18 month

RUN-IN PERIOD: None

PANGlication details
COMMERCIAL FUNDING: yes
NON-COMMERCIAL FUNDING: yes
PUBLICATION STATUS (PEER REVIEW JOURNAL): yes
PUBLICATION STATUS (JOURNAL SUPPLEMENT): no
PUBLICATION STATUS (ABSTRACT): no


Zhou 2005 (Continued)

Stated aim for study

Quote "we hypothesized that LADA patients might benefit from thiazolidinediones treatment"

\section{Notes}

\section{Risk of bias}

\begin{tabular}{lll}
\hline Bias & Authors' judgement & Support for judgement \\
\hline $\begin{array}{l}\text { Random sequence genera- } \\
\text { tion (selection bias) }\end{array}$ & Unclear risk & Not described \\
\hline $\begin{array}{l}\text { Allocation concealment } \\
\text { (selection bias) }\end{array}$ & Low risk & Unblinded \\
\hline $\begin{array}{l}\text { Blinding (performance } \\
\text { bias and detection bias) } \\
\text { All outcomes }\end{array}$ & Unclear risk & No evidence the analyst was blinded \\
\hline $\begin{array}{l}\text { Incomplete outcome data } \\
\text { (attrition bias) } \\
\text { All outcomes }\end{array}$ & High risk & ITT not described, no description of dealing with missing data \\
\hline $\begin{array}{l}\text { Selective reporting (re- } \\
\text { porting bias) }\end{array}$ & Low risk & No problems identified \\
\hline \begin{tabular}{l} 
Other bias \\
\hline
\end{tabular} & High risk & Funded by grant from Glaxo-SmithKline Investment Co. \\
\hline
\end{tabular}

Zhu 2004

Methods RANDOMISED CONTROLLED CLINICAL TRIAL (RCT): yes, parallel RCT

RANDOMISATION RATIO: equal ratio assumed (not stated in manuscript)

NON-INFERIORITY DESIGN: no

EQUIVALENCE DESIGN: no

ETHICS APPROVAL OBTAINED: unknown

PATIENT CONSENT OBTAINED: unknown

BLINDING OF PATIENT (P), EDUCATOR (E), RESEARCHER (R): $P=n o, E=n o, R=$ no

ANALYSIS BY INTENTION TO TREAT: NO

POWER CALCULATION: no

\section{Participants}

\section{WHO PARTCIPATED:}

SEX (female\% / male\%): Insulin group 45\% F(15/33), 54\% M 18/33, Insulin + Chinese medicine 51\% F (16/31), 49\% M (15/31), SU group 45\% F (9/20), 55\% M (11/20).

AGE (mean years (SD)): Insulin group (39.8), Insulin+ Chinese medicine (40.5), SU group (41.6)

ETHNIC GROUPS (\%): not stated

DURATION OF DISEASE (mean months (SD)): Insulin 20.3 (3.6), Insulin + Chinese medicine 19.5 (3.9), SU group $19.8(4.3)$ 
INCLUSION CRITERIA: (1) Adult (32 years +) (2) type 2 diabetes with GADA+ and ICA + .

EXCLUSION CRITERIA: none given

DIAGNOSTIC CRITERIA: type 2 diabetes with GADA+ and ICA+

CO-MORBIDITIES:Not given

CO-MEDICATIONS: Not given

NUMBER: Insulin 33, IInsulin+ Chinese medicine 31, SU 20.

LOSS TO FOLLOW-UP: $0 \%$

COUNTRY/ LOCATION: China

SETTING: out-patient

INTERVENTION (ROUTE, TOTAL DOSE/DAY, FREQUENCY): Insulin or insulin plus Chinese medicine CONTROL (ROUTE, TOTAL DOSE/DAY, FREQUENCY): Sulphonylurea

TREATMENT BEFORE STUDY:None

TITRATION PERIOD: None

\section{Outcomes}

PRIMARY OUTCOME(S) (as stated in the publication):Not stated but abstract states "to study the effect of integrated Chinese and Westerm medicine on improvement of islet beta cell function in treating patients with latent autoimmune diabetes in adults (LADA)"

SECONDARY OUTCOMES (as stated in the publication): Not stated

ADDITIONAL OUTCOMES:

1.HbA1c, 2. FBG, 3. Stimulated C-peptide and changes in C-peptide

PRIMARY OUTCOME(S) (as stated in the publication):

SECONDARY OUTCOMES (as stated in the publication):

ADDITIONAL OUTCOMES:

1. HbA1c (\%), 2. Fasting C-peptide (nmol/L)

Study details

DURATION OF INTERVENTION: 12 months

DURATION OF FOLLOW-UP: 12 months

RUN-IN PERIOD: None

Publication details

LANGUAGE OF PUBLICATION:Chinese

COMMERCIAL FUNDING: no

NON-COMMERCIAL FUNDING: yes

PUBLICATION STATUS (PEER REVIEW JOURNAL): yes

PUBLICATION STATUS (JOURNAL SUPPLEMENT): yes

PUBLICATION STATUS (ABSTRACT): no 
Zhu 2004 (Continued)

Stated aim for study

Quote " To study the effect of integrated Chinese and Westerm medicine on improvement of the islet beta cell function in treating patients with latent autoimmune diabetes mellitus in adults (LADA)"

Notes

\section{Risk of bias}

\begin{tabular}{lll}
\hline Bias & Authors' judgement & Support for judgement \\
\hline $\begin{array}{l}\text { Random sequence genera- } \\
\text { tion (selection bias) }\end{array}$ & Unclear risk & Not described \\
\hline $\begin{array}{l}\text { Allocation concealment } \\
\text { (selection bias) }\end{array}$ & Low risk & Unblinded \\
\hline $\begin{array}{l}\text { Blinding (performance } \\
\text { bias and detection bias) } \\
\text { All outcomes }\end{array}$ & Unclear risk & Unblinded but not indication the analysis was blinded \\
\hline $\begin{array}{l}\text { Incomplete outcome data } \\
\text { (attrition bias) } \\
\text { All outcomes }\end{array}$ & Unclear risk & Not described \\
\hline $\begin{array}{l}\text { Selective reporting (re- } \\
\text { porting bias) }\end{array}$ & Low risk & No problems identified \\
\hline \begin{tabular}{l} 
Other bias \\
\hline
\end{tabular} & Low risk & No problems identified \\
\hline
\end{tabular}

CG: control group; IG = intervention group

Characteristics of excluded studies [ordered by study ID]

\begin{tabular}{ll}
\hline Study & Reason for exclusion \\
\hline Alvarsson 2003 & Not LADA. Type 2 diabetes. Antibody positive patients were excluded. \\
\hline Berkis 2007 & Administration of rhGAD65 for specific autoimmune response. No clinical intervention. \\
\hline Bjork 1996 & Not LADA. Type 1 (classical) diabetes. Patients were insulin dependent at diagnosis. \\
\hline Chaillous 2000 & Not LADA. Type 1 (classical) diabetes. Mainly children. \\
\hline Conget 2005 & $\begin{array}{l}\text { Not LADA. Type } 1 \text { (classical) diabetes. Insulin dependent at diagnosis, due to hyperglycaemia, keto- } \\
\text { sis or diabetic ketoacidosis. }\end{array}$ \\
\hline DCCT Group 1998 & Not LADA. Type 1 (classical) diabetes. \\
\hline Desai 2007 & LADA but not an intervention study \\
\hline Desai 2008 & LADA but not an intervention study \\
\hline E-Longmire 2004 & $\begin{array}{l}\text { Numbers of antibody positive patients treated or followed-up could not be identified. Contact with } \\
\text { authors unsuccessful. }\end{array}$ \\
\hline Goday 1993 & \begin{tabular}{l} 
Not LADA. Type 1 (classical) diabetes. \\
\hline t
\end{tabular}
\end{tabular}




\begin{tabular}{|c|c|}
\hline Study & Reason for exclusion \\
\hline Heise 2005 & Not LADA. Type 1 (classical) diabetes. \\
\hline Karges 2004 & Not LADA. Type 1 (classical) diabetes. Case study. \\
\hline Kobayashi 2002 & Republication of findings in Kobayashi 1996 and Maruyama 2003. No new findings. \\
\hline Leslie 1996 & No intervention. Review. \\
\hline Leslie 2008 & No intervention. Review \\
\hline Linn 1996 & Not LADA. Type 1 (classical) diabetes. \\
\hline Littorin 1999 & No intervention. Observational study. \\
\hline Loriz Peralta 2007 & Observational study \\
\hline Martin 1991 & Not LADA. Type 1 (classical) diabetes. \\
\hline Matsumoto 2005 & Case study. \\
\hline Mattews 1998 & Not LADA. Type 2 diabetes with no antibodies tested. \\
\hline Mayorov A 2005 & Not LADA. Type 2 diabetes. \\
\hline Murao 2008 & LADA but not an intervention study \\
\hline Ovalle 2004 & Not LADA. Type 2 diabetes. No antibodies tested. \\
\hline Pozzilli 1997 & Not LADA. Type 1 (classical) diabetes. \\
\hline Pozzilli 2000 & Not LADA. Type 1 (classical) diabetes. \\
\hline Pugliese 2003 & Not LADA. No intervention. \\
\hline Ravnik-Oblak 1995 & Not LADA. Type 2 diabetes. No antibodies tested. \\
\hline Raz 2007 & Not LADA. Type 1 diabetes (ketones) \\
\hline Rosario 2007 & LADA. Observational. \\
\hline Sa 2003 & Before and after study with no control arm. \\
\hline Schloot 2007 & Not LADA. Type 1 in adults and paediatrics \\
\hline Schories 2004 & Not LADA. Type 1 (classical) diabetes. \\
\hline Scranton 2004 & LADA but no mention of antibody positivity in the selection criteria. \\
\hline Secchi 1990 & Not LADA. Type 1 (classical) diabetes. \\
\hline Steffes 2003 & Not LADA. Type 1 (classical) diabetes. No intervention. \\
\hline Stenstrom 2005 & Review, not a primary study. \\
\hline Takino 1998 & Not an intervention study. Commentary only. \\
\hline
\end{tabular}




\begin{tabular}{ll}
\hline Study & Reason for exclusion \\
\hline Turner 1997 & No intervention. \\
\hline van Deutekom 2007 & LADA systematic review \\
\hline Vidal 2000 & Not LADA. Type 1 (classical) diabetes. \\
\hline Weng 2008 & Type 2 diabetes with no autoantibody testing \\
\hline Zinman 2004 & Not an intervention study. Observational study results. \\
\hline
\end{tabular}

LADA: latent autoimmune diabetes in adults

Characteristics of ongoing studies [ordered by study ID]

\section{Agardh 2004}

\begin{tabular}{ll}
\hline Trial name or title & Safety of Diamyd ${ }^{\circledR}$ in Patients With LADA (Latent Autoimmune Diabetes in Adult) \\
\hline Methods & Randomised Controlled Trial \\
\hline Participants & $\begin{array}{l}\text { Male and female patients between 30-70 years of age, presence of GAD65 antibodies, detectable C- } \\
\text { peptide level, patients requiring treatment with diet and/or oral hypoglycaemic agents (OHA), }\end{array}$ \\
\hline Interventions & rhGAD65 formulated in Alhydrogel ${ }^{\circledR}$ (Diamyd ${ }^{\circledR}$ ) compared to placebo \\
\hline Outcomes & HbAlc, C-peptide, blood glucose and insulin requirement \\
\hline Starting date & December 2004 \\
\hline Contact information & Carl-David Agardh. University Hospital MAS, Malmo, Sweden \\
\hline Notes &
\end{tabular}

Brophy 2007

\begin{tabular}{ll}
\hline Trial name or title & $\begin{array}{l}\text { Randomised, controlled, parallel-group study to investigate the clinical effectiveness of early in- } \\
\text { sulin treatment in patients with LADA }\end{array}$ \\
\hline Methods & Randomised Controlled Trial \\
\hline Participants & GAD positive (101+ WHO Units) Type 2 within 12 months of diagnosis \\
\hline Interventions & $\begin{array}{l}\text { Insulin or standard care (diet, followed by metformin, followed by glitazone with or without met- } \\
\text { formin, followed by insulin) }\end{array}$ \\
\hline Outcomes & HbAlc, FCP, Weight, GAD antibody, HOMA, Quality of life, blood pressure/total cholesterol. \\
\hline Starting date & 2007 \\
\hline Contact information & Brophy S, School of Medicine, Swansea University. s.brophy@swansea.ac.uk \\
\hline
\end{tabular}


Brophy 2007 (Continued)

Notes
This trial has been officially terminated early (before the specified date for its conclusion in the protocol) due to the low recruitment rate of participants.

Buzzetti 2006

\begin{tabular}{ll}
\hline Trial name or title & Non Insulin Requiring Autoimmune Diabetes (NIRAD) project \\
\hline Methods & Randomised controlled trial \\
\hline Participants & GAD or IA-2 positive T2DM already on treatment \\
\hline Interventions & Insulin or metformin \\
\hline Outcomes & beta cell failure using stimulated C-peptide \\
\hline Starting date & \begin{tabular}{l}
2006 \\
\hline Contact information
\end{tabular} \\
$\begin{array}{l}\text { Raffaella Buzzetti, Dept. of Endocrinology and Diabetes } \\
\text { University Campus Bio-Medico } \\
\text { Via E. Longoni, 83 } \\
\text { Rome 00155 } \\
\text { Italy }\end{array}$ \\
\hline
\end{tabular}

Notes

\section{Grill 2010}

\begin{tabular}{ll}
\hline Trial name or title & Is "Beta Cell Rest" by Insulin Treatment Beneficial Compared to State-of-the Art Enhancers of In- \\
sulin Secretion in Preserving Beta Cell Function in Subjects With Latent Autoimmune Diabetes of \\
the Adult (LADA)?
\end{tabular}

\begin{tabular}{ll}
\hline Methods & Randomised controlled trial \\
\hline Participants & $\begin{array}{l}\text { Diabetes diagnosed during } 0-3 \text { years before entering the study, age }>\text { or equal to } 30 \text { years }<\text { or equal } \\
\text { to } 75 \text { years, anti-GAD positivity, fasting C-peptide }>\text { or equal to } 0,3 \text { ng } / \text { ml, no need for insulin treat- } \\
\text { ment by clinical judgement for at least } 3 \text { months following the diagnosis of diabetes, HbAlc }>15 \% \\
\text { above the upper limit of normal. }\end{array}$ \\
\hline
\end{tabular}

Interventions Metformin + NPH insulin compared to metformin + sitagliptin +/- repaglinide

\begin{tabular}{ll}
\hline Outcomes & Fasting and glucagon-stimulated C-peptide, HbAlc \\
\hline Starting date & March 2009 \\
\hline Contact information & Valdemar Grill Te: 47 72825188 email:valdemar.grill@ntnu.no \\
\hline
\end{tabular}

\section{Notes}


Palmer 2000

\begin{tabular}{ll}
\hline Trial name or title & Rosiglitazone intervention study on patients with type 1.5 diabetes \\
\hline Methods & Randomised controlled trial \\
\hline Participants & Antibody positive T2 diabetes, aged 35 to 69 years, no history of ketonuria. \\
\hline Interventions & Rosiglitazone or glyburide (SU) \\
\hline Outcomes & Fasting and stimulated C peptide, Antibody levels \\
\hline Starting date & 2000 \\
\hline Contact information & Jerry Palmer, Seattle Institute for Biomedical and Clinical Research, University of Washington. \\
\hline Notes & \\
\hline
\end{tabular}

\section{Palmer 2009}

$\begin{array}{ll}\text { Trial name or title } & \text { Safety, Tolerability, Immunological and Clinical Efficacy of Multiple Subcutaneous Doses of Dia- } \\ \text { Pep277 in Latent Autoimmune Diabetes in Adults (LADA) }\end{array}$

Pep277 in Latent Autoimmune Diabetes in Adults (LADA)

\begin{tabular}{ll}
\hline Methods & Randomised controlled trial \\
\hline Participants & $\begin{array}{l}\text { Diabetes according to WHO criteria, duration 2 month to 5 years, diabetes controlled by diet and } \\
\text { insulin for } 2 \text { or more weeks, aged } 30 \text { to 65, positive for GAD autoantibodies, fasting C-peptide of 0.3 } \\
\text { nmol/L or greater at screening }\end{array}$ \\
\hline Interventions & DiaPep277 compared to placebo \\
\hline Outcomes & Undefined \\
\hline Starting date & October 2002 \\
\hline Contact information & Jerry P Palmer University of Washington. \\
\hline Notes & \\
\hline
\end{tabular}

\section{Zhou 2010}

Trial name or title $\quad$ Protective Effects of Sitagliptin on $\beta$ Cell Function in Patients With Adult-onset Latent Autoimmune
Diabetes(LADA) (DPP-NLADA)

\begin{tabular}{ll}
\hline Methods & Randomized controlled trial \\
\hline Participants & $\begin{array}{l}\text { Age } 25-70, \text { Diabetes diagnosed according to the report of WHO in 1999, disease duration of less } \\
\text { than } 3 \text { year, no ketoacidosis within the first } 6 \text { months after diagnosis of diabetes, GADA positive } \\
\text { twice within one month, FCP level of } 0.2 \mathrm{nmol} / \mathrm{L} \text { or more. }\end{array}$ \\
\hline Interventions & Sitagliptin combined with insulin therapy compared to sitagliptin \\
\hline Outcomes & HOMA-IR, Intravenous glucose tolerance test (assessment of beta cell function) \\
\hline
\end{tabular}


Zhou 2010 (Continued)

Starting date May 2010

Contact information

Zhiguang Zhou, Diabetes Center, Institute of Metabolism and Endocrinology, Second Xiangya Hospital, Central South University, China

Notes

DATA AND ANALYSES

Comparison 1. HbA1c mean difference in insulin compared to tablet

\begin{tabular}{llllll}
\hline Outcome or subgroup title & $\begin{array}{l}\text { No. of } \\
\text { studies }\end{array}$ & $\begin{array}{l}\text { No. of } \\
\text { partici- } \\
\text { pants }\end{array}$ & Statistical method & Effect size \\
\hline $\begin{array}{l}1 \text { Average mean difference in HbA1c from } \\
\text { baseline to endpoint }\end{array}$ & 4 & 160 & $\begin{array}{l}\text { Mean Difference (IV, Random, 95\% } \\
\text { Cl) }\end{array}$ & $-1.26[-2.39,-0.12]$ \\
\hline $\begin{array}{l}2 \text { Mean difference of HbAlc at study end } \\
\text { point }\end{array}$ & 4 & 160 & $\begin{array}{l}\text { Mean Difference (IV, Random, 95\% } \\
\text { Cl) }\end{array}$ & $-1.24[-2.49,0.02]$ \\
\hline
\end{tabular}

Analysis 1.1. Comparison 1 HbA1c mean difference in insulin compared to tablet, Outcome 1 Average mean difference in $\mathrm{HbA1c}$ from baseline to endpoint.

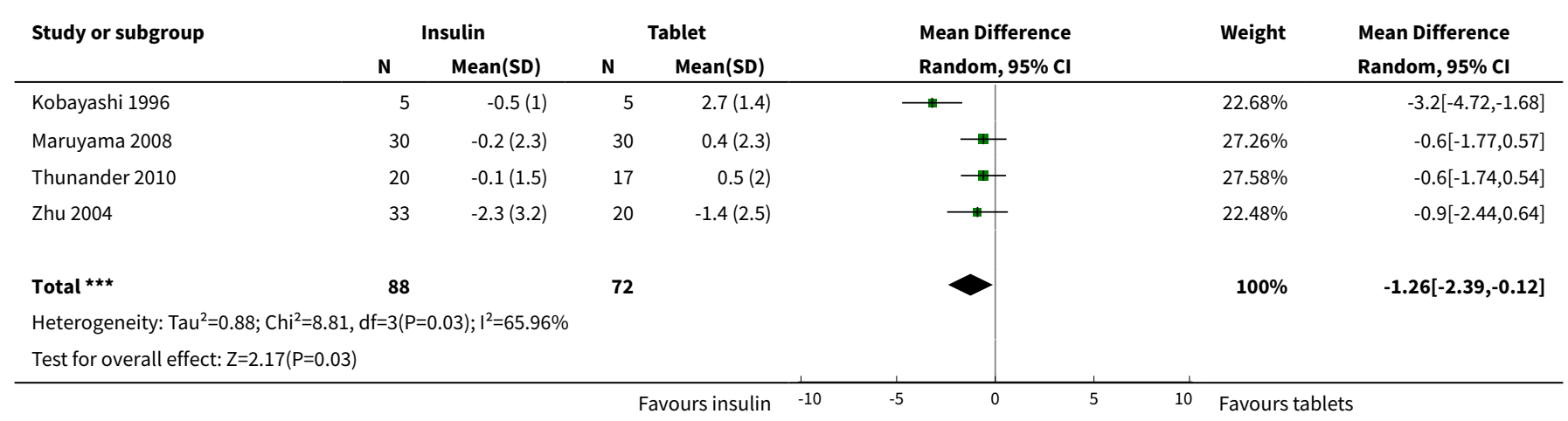

Analysis 1.2. Comparison $1 \mathrm{HbA1c}$ mean difference in insulin compared
to tablet, Outcome 2 Mean difference of HbA1c at study end point.

\begin{tabular}{|c|c|c|c|c|c|c|c|}
\hline \multirow[t]{2}{*}{ Study or subgroup } & \multicolumn{2}{|c|}{ Insulin } & \multicolumn{2}{|c|}{ Tablet } & \multirow{2}{*}{$\begin{array}{l}\text { Mean Difference } \\
\text { Random, } 95 \% \mathrm{Cl}\end{array}$} & \multirow[t]{2}{*}{ Weight } & \multirow{2}{*}{$\begin{array}{l}\text { Mean Difference } \\
\text { Random, 95\% Cl }\end{array}$} \\
\hline & $\mathbf{N}$ & Mean(SD) & $\mathbf{N}$ & Mean(SD) & & & \\
\hline Kobayashi 1996 & 5 & $7.3(0.9)$ & 5 & $11.2(1.3)$ & & $21.76 \%$ & $-3.9[-5.29,-2.51]$ \\
\hline Maruyama 2008 & 30 & $7.2(1.6)$ & 30 & $7.7(1.4)$ & - & $26.72 \%$ & $-0.5[-1.26,0.26]$ \\
\hline Thunander 2010 & 20 & $7.2(0.7)$ & 17 & $7.5(1.5)$ & II & $26.61 \%$ & $-0.3[-1.08,0.48]$ \\
\hline Zhu 2004 & 33 & $6.6(2.1)$ & 20 & $7.3(1.6)$ & 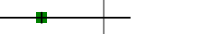 & $24.91 \%$ & $-0.7[-1.7,0.3]$ \\
\hline
\end{tabular}




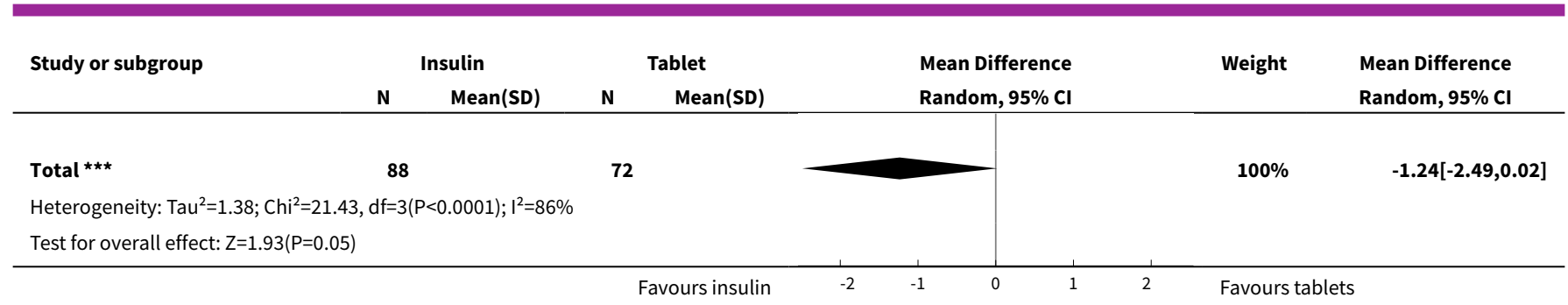

\section{Comparison 2. Sensitivity analysis}

\begin{tabular}{llllll}
\hline Outcome or subgroup title & $\begin{array}{l}\text { No. of } \\
\text { studies }\end{array}$ & $\begin{array}{l}\text { No. of } \\
\text { partici- } \\
\text { pants }\end{array}$ & Statistical method & Effect size \\
\hline 1 HbAlc at final point & 5 & 313 & Mean Difference (IV, Random, 95\% Cl) & $-1.11[-2.04,-0.18]$ \\
\hline $\begin{array}{l}2 \text { Mean difference from baseline at } \\
\text { study endpoint }\end{array}$ & 5 & 313 & Mean Difference (IV, Random, 95\% Cl) & $-0.96[-1.90,-0.02]$ \\
\hline
\end{tabular}

Analysis 2.1. Comparison 2 Sensitivity analysis, Outcome $1 \mathrm{HbA1c}$ at final point.

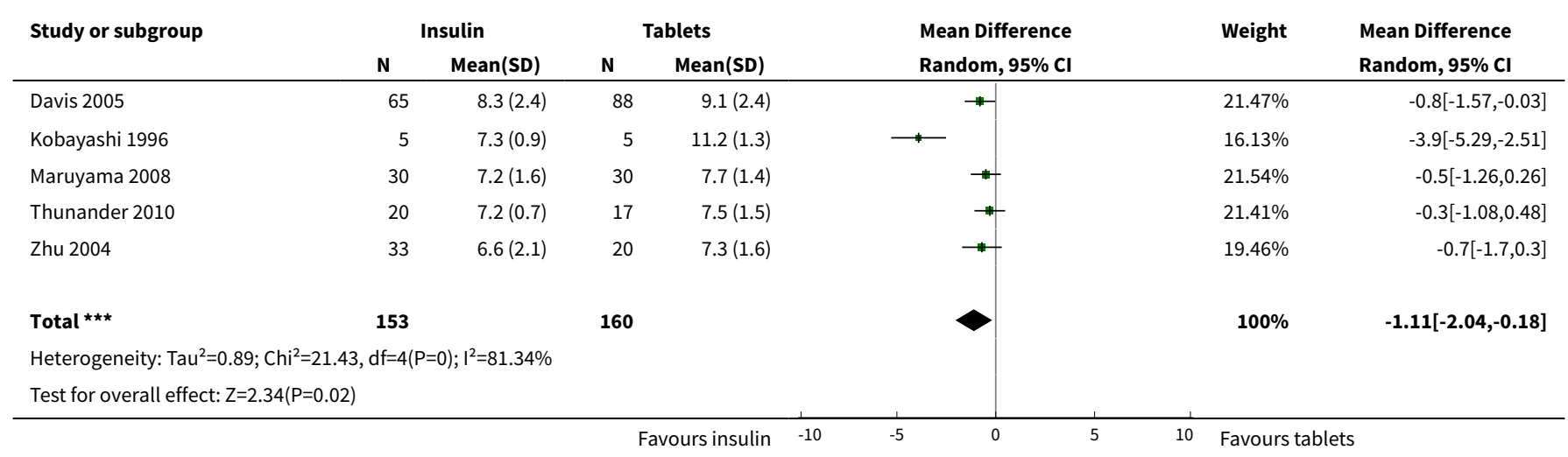

Analysis 2.2. Comparison 2 Sensitivity analysis, Outcome 2 Mean difference from baseline at study endpoint.

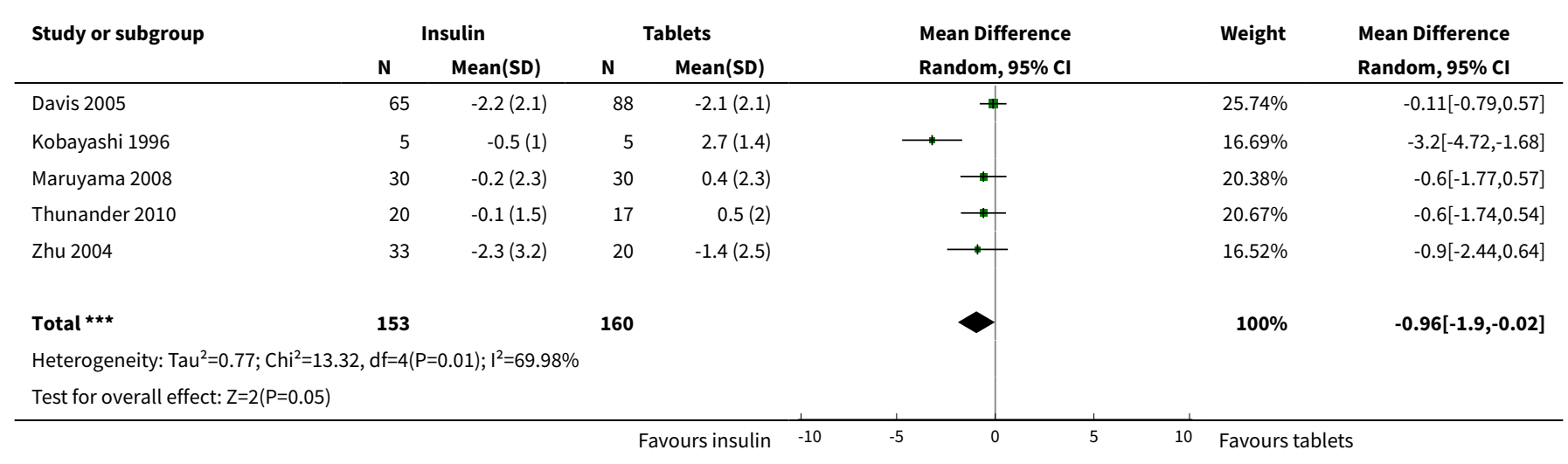


ADDITIONAL TABLES 


\begin{tabular}{|c|c|c|c|c|c|c|c|}
\hline Study ID & Intervention(s) \& control(s) & [n] screened & $\begin{array}{l}\text { [n] ran- } \\
\text { domised }\end{array}$ & $\begin{array}{l}\text { [n] adverse } \\
\text { events }\end{array}$ & [n] ITT & $\begin{array}{l}\text { [n] finishing } \\
\text { study }\end{array}$ & $\begin{array}{l}\text { [\%] of randomised } \\
\text { participants } \\
\text { finishing study }\end{array}$ \\
\hline \multirow{3}{*}{$\begin{array}{l}\text { Cabr- } \\
\text { era-Rode } \\
2002\end{array}$} & I1: Insulin + SU & I1: - & I1: 6 & I1: - & I1: 6 & $11: 6$ & I1: $100 \%$ \\
\hline & C1: Insulin & C1: - & $\mathrm{C} 1: 8$ & C1: - & $\mathrm{C} 1: 8$ & $\mathrm{C} 1: 8$ & C1: $100 \%$ \\
\hline & & $\mathrm{T}:-$ & $\mathrm{T}: 14$ & T: - & $\mathrm{T}: 14$ & $\mathrm{~T}: 14$ & $\mathrm{~T}: 100 \%$ \\
\hline \multirow[t]{3}{*}{ Davis 2005} & I1: Insulin (in patients with FBG > 14.9 & I1: - & I1: - & I1: - & I1: - & I1: 65 & I1: - \\
\hline & & C1: - & C1: - & C1: - & C1: - & $\mathrm{C} 1: 88$ & C1:- \\
\hline & $\begin{array}{l}\text { C1: SU (in patients with a FBG > } 14.9 \\
\mathrm{mmol} / \mathrm{L} \text { ) }\end{array}$ & $\begin{array}{l}\text { T: } 5102 \text { (all pa- } \\
\text { tients type } 2 \text { and } \\
\text { LADA) }\end{array}$ & $\mathrm{T}: 164$ & T: - & T: - & $\mathrm{T}: 153$ & $\mathrm{~T}: 93 \%$ \\
\hline \multirow[t]{4}{*}{ Davis 2005} & $\begin{array}{l}\text { I1: Insulin (in patients with FBG }<15 \\
\mathrm{mmol} / \mathrm{L} \text { ) }\end{array}$ & I1: - & I1: - & I1: - & I1: - & I1: 95 & \\
\hline & & 12:- & 12:- & 12:- & 12: - & I2: 140 & 12:- \\
\hline & $\begin{array}{l}\text { 12: SU (in patients with } \mathrm{FBG}<15 \mathrm{mmol} / \\
\mathrm{L} \text { ) }\end{array}$ & $\mathrm{C} 1:-$ & C1: - & C1: - & C1: - & $C 1: 100$ & C1: - \\
\hline & $\begin{array}{l}\text { C1: Conventional (in patients with FBG } \\
<15 \mathrm{mmol} / \mathrm{L} \text { ) }\end{array}$ & $\begin{array}{l}\mathrm{T}: 5102 \text { (all pa- } \\
\text { tients type } 2 \text { and } \\
\text { LADA) }\end{array}$ & $\mathrm{T}: 362$ & $\mathrm{~T}:-$ & T: - & $\mathrm{T}: 335$ & $\mathrm{~T}: 93 \%$ \\
\hline \multirow{3}{*}{$\begin{array}{l}\text { L-Hallin } \\
1999\end{array}$} & I1: SU + insulin & I1: - & $11: 3$ & I1: - & |1: - & $11: 2$ & I1: $66 \%$ \\
\hline & C1:Placebo + insulin & C1: - & $\mathrm{C} 1: 12$ & C1: - & C1: - & $\mathrm{C} 1: 11$ & C1: $92 \%$ \\
\hline & & $\mathrm{T}:-$ & $\mathrm{T}: 15$ & $\mathrm{~T}:-$ & $\mathrm{T}:-$ & $\mathrm{T}: 13$ & T: $87 \%$ \\
\hline \multirow[t]{6}{*}{ Agardh 2005} & I1: GAD65 (4 ug) & I1: - & $11: 9$ & $\mid 1: 10$ & $\mathrm{I}: \mathrm{n} / \mathrm{a}$ & I1: 9 & I1: $100 \%$ \\
\hline & 12: GAD65 (20 ug) & 12:- & $12: 8$ & 12: 7 & I2: n/a & 12: 8 & 12: $100 \%$ \\
\hline & I3: GAD65 (100 ug) & 13:- & 13: 9 & 13: 9 & I3: n/a & 13: 9 & I3: $100 \%$ \\
\hline & 14: GAD65 (500 ug) & 14: - & 14: 8 & 14: 12 & 14: n/a & 14: 8 & 14: $100 \%$ \\
\hline & C1: Placebo & C1:- & $\mathrm{C} 1: 13$ & $\mathrm{C} 1: 13$ & $\mathrm{C} 1: \mathrm{n} / \mathrm{a}$ & $\mathrm{C} 1: 13$ & $\mathrm{C} 1: 100 \%$ \\
\hline & & $\mathrm{T}:-$ & $\mathrm{T}: 47$ & $\mathrm{~T}: 51$ & $\mathrm{~T}: \mathrm{n} / \mathrm{a}$ & $\mathrm{T}: 47$ & $\mathrm{~T}: 100 \%$ \\
\hline Agardh 2009 & I1: GAD65 (4 ug) & 11:- & I1: 9 & $\mid 1: 0$ & I1: PPA & $11: 7$ & I1: $78 \%$ \\
\hline
\end{tabular}




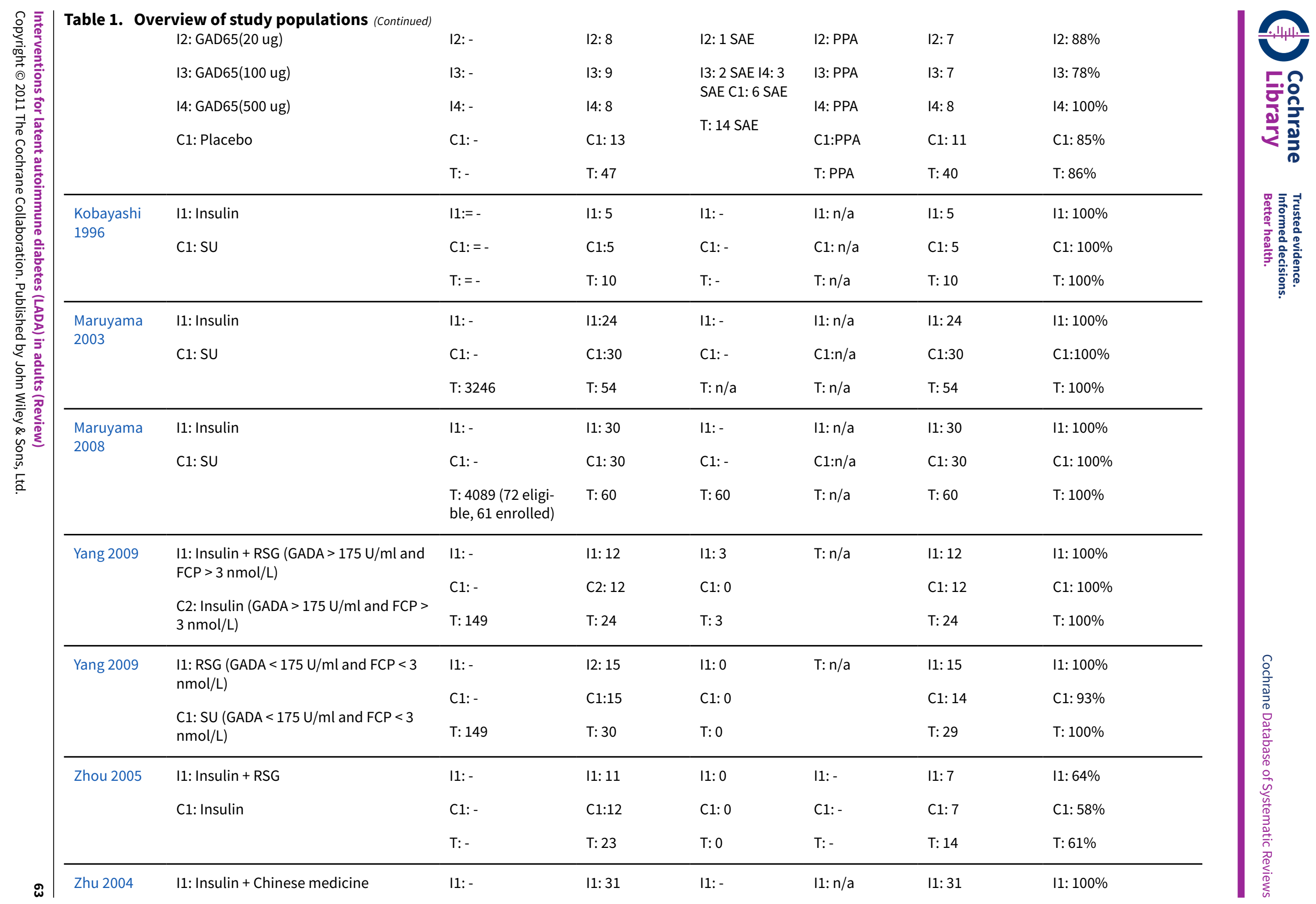




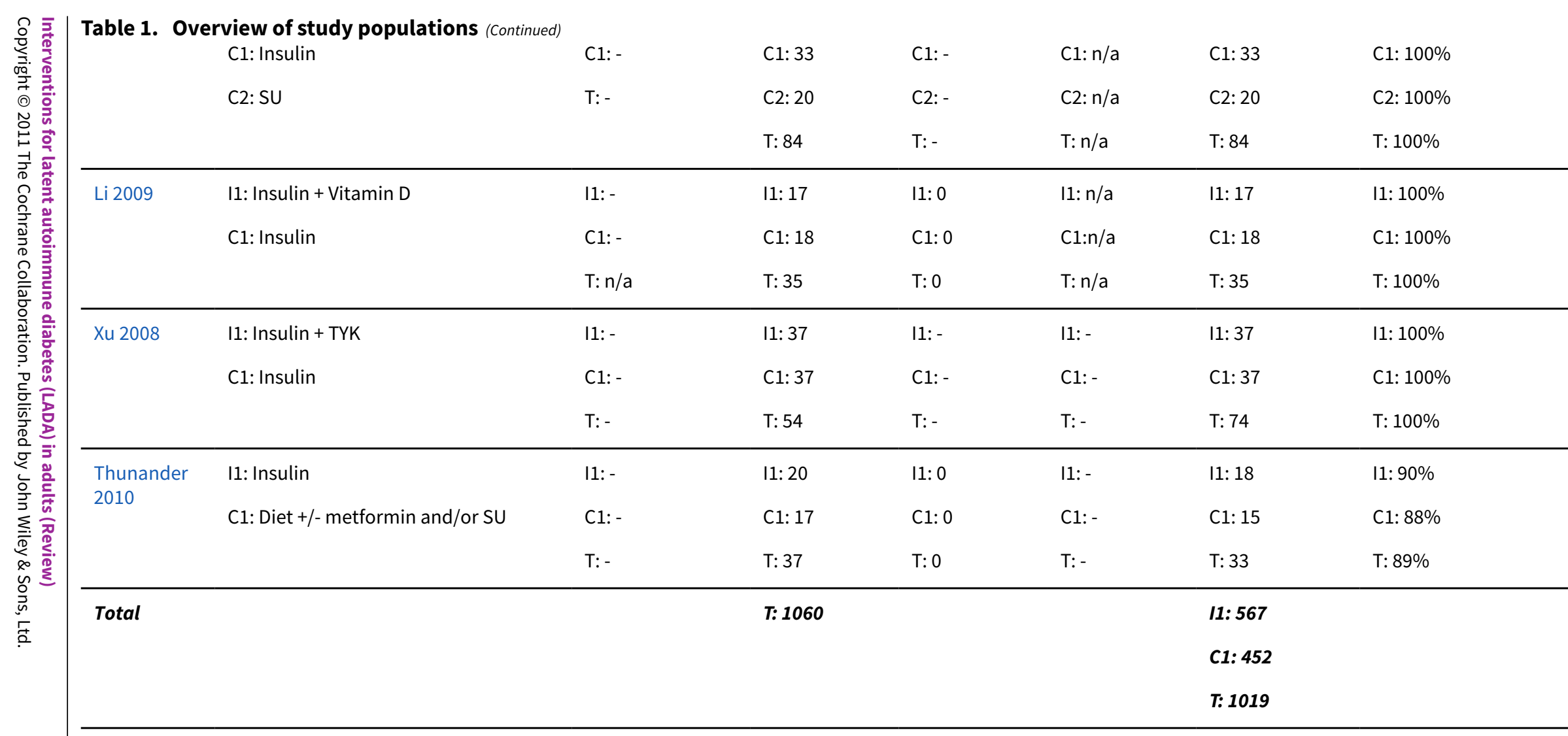

'-' denotes not reported

C: control; FCP: fasting C-peptide; FBG: fasting blood glucose; GADA: glutamic acid decarboxylase antibodies; I: intervention; ITT: intention-to-treat; n/a: not applicable; PPA: per protocol analysis; RSG: rosiglitazone; SAE: serious adverse events; SU: sulphonylurea; T: Total 


\section{AP PEN DICES}

\section{Appendix 1. Search strategies}

\section{Search terms}

Unless otherwise stated, search terms are free text terms; MeSH = Medical subject heading (Medline medical index term); exp = exploded MeSH; the dollar sign (\$) stands for any character(s); the question mark (?) substitutes one or no character; tw = text word; pt = publication type; $\mathrm{sh}=\mathrm{MeSH}$; adj = adjacent.

\section{MEDLINE}

I. Latent autoimmune diabetes (LADA):

1. LADA.tw.

2. SPIDDM.tw.

3. exp Diabetes Mellitus/

4. diabet\$.tw.

5. or/1-4

6. slowly progressiv\$.tw.

7. islet antibod\$.tw.

8. islet cell antibod\$.tw.

9. (autoantibod\$ or auto-antibod\$).tw.

10. exp Autoantibodies/

11. glutamic acid\$ decarboxylas\$.tw.

12. IA-2.tw.

13. exp "Islets of Langerhans"/

14. GAD.tw.

15. exp Glutamate Decarboxylase/

16. or/6-15

\section{5 and 16}

\section{RCT/CCT (senitive search)}

Part 1:

18. randomized controlled trial.pt.

19. controlled clinical trial.pt.

20. randomized controlled trials.sh.

21. random allocation.sh.

22. double-blind method.sh.

23. single-blind method.sh.

24. or $/ 18-23$

Part 2:

25. clinical trial.pt.

26. exp clinical trials/

27. (clinic\$ adj25 trial\$).ab,ti,ot.

28. ((singl\$ or doubl\$ or trebl\$ or tripl\$) adj (mask\$ or blind\$)).ab,ti,ot.

29. placebos.sh.

30. placebo\$.ab,ti,ot.

31. random $\$$.ab,ti,ot.

32. research design.sh.

33. (latin adj square).ab,ti,ot.

34. or/25-33

Part 3:

35. comparative study.pt.

36. exp evaluation studies/

37. follow-up studies.sh.

38. prospective studies.sh.

39. (control\$ or prospectiv\$ or volunteer\$).ab,ti,ot. 
(Continued)

40. cross-over studies.sh.

41. or $/ 35-40$

42. 24 or 34 or 41

III. Meta-analysis:

43. exp meta-analysis/

44. exp Review Literature/

45. meta-analysis.pt.

46. (meta-analy\$ or meta?analy\$).ab,ti,ot.

47. ((review\$ or search\$) and (medical databas\$ or medline or pubmed or embase or cochrane or systematic\$)).ab,ti,ot.

48. or/43-47

49. letter.pt.

50. comment.pt.

51. editorial.pt.

52. historical-article.pt.

53. or/49-52

54. ((systematic\$ or quantitativ\$ or methodologic\$) adj (review\$ or overview\$)).ab,ti,ot.

55. (integrativ\$ research review\$ or research integration\$).ab,ti,ot.

56. quantitativ\$ synthes\$.ab,ti,ot.

57. (pooling\$ or pooled analys\$ or mantel\$ haenszel\$).ab,ti,ot.

58. (peto\$ or der?simonian\$ or fixed effect\$ or random effect\$).ab,ti,ot.

59. or $/ 54-58$

60.48 not 53

61.59 or 60

IV. LADA + RCT/CCT:

62. 17 and 42

V. LADA + Meta-analysis:

63. 17 and 61

VI. IV. + V.

64.62 or 63

65. limit 64 to $y r=" 2007-2010 "$

66. limit 65 to "all adult (19 plus years)"

\section{Web of Knowledge}

Topic=(Diabetes Mellitus OR diabet* OR LADA OR SPIDDM) AND Topic=(slowly progressiv ${ }^{\star}$ OR islet antibod ${ }^{\star}$ OR islet cell antibod ${ }^{\star}$ OR autoantibod* OR auto-antibod* OR Autoantibodies OR glutamic acid* decarboxylas* OR IA-2 OR "Islets of Langerhans" OR GAD OR Glutamate Decarboxylase) AND Topic=(ADULT)

Timespan=2007-2010. Databases=SCI-EXPANDED, SSCI, CPCI-S, CPCI-SSH.

\section{ASSIA (CSA)}

1. $K W=L A D A$

2. $K W=S P I D D M$

3. $\mathrm{DE}=$ "diabetes mellitus" [Assia Thesaurus term]

4. $\mathrm{KW}=$ diabet $^{\star}$

5. (1 OR 2 OR 3 OR 4)

6. $\mathrm{KW}=$ slowly progressiv ${ }^{*}$

7. $\mathrm{KW}=$ =islet antibod ${ }^{\star}$

8. $\mathrm{KW}=$ islet cell antibod ${ }^{\star}$ 
(Continued)
9. $\mathrm{KW}=$ (autoantibod $^{*}$ or auto-antibod $\left.{ }^{\star}\right)$
10. KW=(glutamic acid ${ }^{\star}$ decarboxylas ${ }^{\star}$ )
11. $\mathrm{KW}=\mathrm{IA}-2$
$12 \mathrm{KW}=\mathrm{GAD}$
13. $\mathrm{KW}=$ Islets of Langerhans
14. (6 OR7 OR 8 OR9 OR 10 OR11 OR 12 OR 13
15. (5 AND 14)
16. LIMIT 15 to $2007-2010$

\section{CINAHL}
1. LADA

2. SPIDDM

3. MH "Diabetes Mellitus+" [Cinahl Subject Heading - exploded]

4. diabet*

5. or/1-4

6. slowly progressive ${ }^{\star}$

7. islet antibody ${ }^{\star}$

8. islet cell antibody ${ }^{\star}$

9. (autoantibody ${ }^{\star}$ or auto-antibod ${ }^{\star}$ )

10. MH "Autoantibodies"

11. glutamic acid* decarboxylas*

12. IA-2

13. MH "Islets of Langerhans"

14. GAD.tw.

15. Glutamate Decarboxylase [Not a Cinahl Subject Heading]

16. or/6-15

17. (5 and 16)

18. Limit 17 to Publication Year 2007-2010

19. Limit 18 to Age Groups Adult 19+

\section{The Cochrane Library}
1. LADA
2. SPIDDM
3. MH "Diabetes Mellitus+" [MESH term - exploded]
4. diabet*
5. or/1-4 
(Continued)

6. slowly progressive*

7. islet antibody*

8. islet cell antibody ${ }^{\star}$

9. (autoantibody* or auto-antibod*)

10. MH "Autoantibodies+" [MESH term - exploded]

11. glutamic acid* decarboxylas*

12. IA-2

13. MH "Islets of Langerhans+" [MESH term - exploded]

14. GAD

15. MH "Glutamate Decarboxylase" [MESH term]

16. or/6-15

17. (5 and 16)

18. Limit 17 to Publication Year 2007-2010

\section{EMBASE}

1 LADA.tw.

2 SPIDDM.tw.

3 diabet\$.tw.

4 exp Diabetes Mellitus/

5 or $/ 1-4$

6. slowly progressiv\$.tw.

7 islet antibod\$.tw.

8 islet cell antibod\$.tw.

9 (autoantibod\$ or auto-antibod\$).tw.

10 exp Autoantibodies/

11 glutamic acid\$ decarboxylas\$.tw.

12 IA-2.tw

13 GAD.tw.

14 exp Glutamate Decarboxylase/

15 exp pancreas islet/

16 islet of langerhans.mp.

17 or/6-16

$18 \quad 5$ and 17

19 exp adult/

20 human/ 
(Continued)

$21 \quad 18$ and 19 and 20

22 LIMIT 2007-2010

NOTE - keywords were all searched in the TITLE, ABSTRACT, and KEYWORDS fields.

Appendix 2. Selection criteria for LADA

\begin{tabular}{|c|c|c|c|c|c|}
\hline Study & Age & Diagnosis & Antibody & Ketoacidosis & Comments \\
\hline $\begin{array}{l}\text { Agardh } \\
2005\end{array}$ & $30-70$ & Type 2 & GAD & Not specifically mentioned & $\begin{array}{l}\text { Diagnosed within past } 5 \text { years and not re- } \\
\text { quiring insulin }\end{array}$ \\
\hline \multicolumn{6}{|l|}{$\begin{array}{l}\text { Agardh } \\
2009\end{array}$} \\
\hline $\begin{array}{l}\text { Cabr- } \\
\text { era-Rode } \\
2002\end{array}$ & $\begin{array}{l}\text { None giv- } \\
\text { en }\end{array}$ & Type 2 & $\begin{array}{l}\text { GAD and } \\
\text { ICA }\end{array}$ & $\begin{array}{l}\text { No ketoacidosis in one } \\
\text { month treated with insulin } \\
\text { and sulphonylureas }\end{array}$ & $\begin{array}{l}\text { Divided into disease durations of up to } 3 \\
\text { years and } 3 \text { years + }\end{array}$ \\
\hline $\begin{array}{l}\text { Kobayashi } \\
1996\end{array}$ & $\begin{array}{l}\text { None giv- } \\
\text { en }\end{array}$ & Type 2 & ICA & $\begin{array}{l}\text { No ketoacidosis or initial } \\
\text { need for insulin }\end{array}$ & \\
\hline $\begin{array}{l}\text { Kobayashi } \\
2002\end{array}$ & $\begin{array}{l}\text { None giv- } \\
\text { en }\end{array}$ & $\begin{array}{l}\text { None in- } \\
\text { sulin de- } \\
\text { pendent di- } \\
\text { abetes }\end{array}$ & ICA & Not specifically mentioned & \\
\hline $\begin{array}{l}\text { Davis } \\
2005\end{array}$ & $25-65$ & $\begin{array}{l}\text { Type } 2 \text { dia- } \\
\text { betes }\end{array}$ & $\begin{array}{l}\text { GAD and/ } \\
\text { or ICA } \\
\text { and/or IA2 }\end{array}$ & No ketonuria & \\
\hline $\begin{array}{l}\text { L-Hallin } \\
1999\end{array}$ & $35-75$ & $\begin{array}{l}\text { Type } 2 \text { dia- } \\
\text { betes }\end{array}$ & GAD & Not specifically mentioned & $\begin{array}{l}\text { BMI } 22-32 \mathrm{~kg} / \mathrm{m} 2 \text {, previous successful re- } \\
\text { sponse to } \mathrm{SU} \text {, fasting blood glucose }>8 \\
\mathrm{mmol} / \mathrm{L} \text { and/or postprandial blood glu- } \\
\text { cose }>11 \mathrm{mmol} / \mathrm{L} \text { and/or HbA1c }>3 \% \text { above } \\
\text { normal per local standard, despite treat- } \\
\text { ment with maximal doses of SU for at least } 3 \\
\text { months. }\end{array}$ \\
\hline Li 2009 & $20+$ & $\begin{array}{l}\text { Type } 2 \text { dia- } \\
\text { betes }\end{array}$ & GAD & $\begin{array}{l}\text { No ketosis within the first } 6 \\
\text { months after diagnosis }\end{array}$ & $\begin{array}{l}\text { Disease duration less than } 5 \text { years, fasting } C \\
\text { peptide }>200 \mathrm{pmol} / \mathrm{l} \text { at entry. }\end{array}$ \\
\hline $\begin{array}{l}\text { Maruya- } \\
\text { ma } 2003\end{array}$ & $\begin{array}{l}\text { None giv- } \\
\text { en }\end{array}$ & $\begin{array}{l}\text { Diabetes } \\
\text { not treated } \\
\text { with insulin }\end{array}$ & GAD & No ketoacidosis & $\begin{array}{l}\text { Not treated with insulin for at least } 6 \text { months } \\
\text { after diagnosis. Disease duration less than } \\
10 \text { years. }\end{array}$ \\
\hline $\begin{array}{l}\text { Maruya- } \\
\text { ma } 2008\end{array}$ & $\begin{array}{l}\text { None giv- } \\
\text { en }\end{array}$ & $\begin{array}{l}\text { Diabetes } \\
\text { not treated } \\
\text { with insulin }\end{array}$ & GAD & No ketosis or ketoacidosis & $\begin{array}{l}\text { Patients should use SU agents to obtain } \\
\text { good glycemic control and the duration of } \\
\text { diabetes should be within } 5 \text { years form on- } \\
\text { set. }\end{array}$ \\
\hline
\end{tabular}

\begin{tabular}{lll}
\hline Xu $2008 \quad$ None giv- \\
en
\end{tabular}




\begin{tabular}{llllll}
$\begin{array}{l}\text { (Continued) } \\
\text { Yang 2009 }\end{array}$ & $25+$ & $\begin{array}{l}\text { Type 2 dia- } \\
\text { betes }\end{array}$ & GAD & $\begin{array}{l}\text { No ketosis within } 6 \text { months of } \\
\text { diagnosis }\end{array}$ & $\begin{array}{l}\text { Diseasea duration less than } 5 \text { years. Fast- } \\
\text { ing C-pepide level of } 0.2 \text { nmol/L or more, not } \\
\text { treated with diet alone. }\end{array}$ \\
\hline Zhou 2005 & $25+$ & Diabetes & GAD & $\begin{array}{l}\text { No ketoacidosis within } 6 \\
\text { months of diagnosis }\end{array}$ & $\begin{array}{l}\text { Disease duration less than } 5 \text { years. Fasting } \\
\text { C-peptide of } 0.3 \text { mmol/L or more. }\end{array}$ \\
\hline Zhu 2004 & $\begin{array}{l}\text { None giv- } \\
\text { en }\end{array}$ & $\begin{array}{l}\text { Type 2 dia- } \\
\text { betes }\end{array}$ & $\begin{array}{l}\text { GAD and } \\
\text { ICA }\end{array}$ & Not specifically mentioned & Not treated with insulin \\
\hline $\begin{array}{l}\text { Thunan- } \\
\text { der } 2010\end{array}$ & $\geq 30$ & Diabetes & $\begin{array}{l}\text { GADA } \\
\text { and/or } \\
\text { ICA }\end{array}$ & Not specifically mentioned & Non-insulin requiring. \\
\hline
\end{tabular}

\section{Footnotes}

GAD: glutamic acid decarboxylase; ICA: islet cells

\section{Appendix 3. Comparison of treatments - difference in means between groups at study end}




\begin{tabular}{|c|c|c|c|c|c|c|c|c|c|}
\hline Study & Comparison & Number & $\begin{array}{l}\text { HbA1c at } 0 \text { to } \\
12 \text { month }\end{array}$ & $\begin{array}{l}\text { HbAlc at } \\
13 \text { month } \\
+\end{array}$ & $\begin{array}{l}\text { FBG at } \\
0 \text { to } 12 \\
\text { month }\end{array}$ & $\begin{array}{l}\text { FBG } \\
\text { at } 13 \\
\text { months } \\
+\end{array}$ & $\begin{array}{l}\text { FCP at } \\
0 \text { to } 12 \\
\text { month }\end{array}$ & $\begin{array}{l}\text { FCP } \\
\text { at } 13 \\
\text { months } \\
+\end{array}$ & Comments \\
\hline $\begin{array}{l}\text { Kobayashi } \\
1996\end{array}$ & Insulin vs SU & 10 & - & $\begin{array}{l}-3.9 \% \\
(-2.5 \% \text { to }- \\
5.2 \%)\end{array}$ & - & $\begin{array}{l}-2.8(-0.9 \\
\text { to }-4.7)\end{array}$ & - & - & \\
\hline Zhu 2004 & Insulin vs SU & 64 & $\begin{array}{l}-0.7 \%(-0.3 \% \text { to } \\
1.7 \%)\end{array}$ & - & $\begin{array}{l}-0.7(-0.7 \\
\text { to } 2.1)\end{array}$ & - & - & - & \\
\hline Zhu 2004 & $\begin{array}{l}\text { Insulin vs insulin and Chi- } \\
\text { nese medicine }\end{array}$ & 64 & $\begin{array}{l}+0.5 \%(-0.46 \% \\
\text { to } 1.46)\end{array}$ & - & $\begin{array}{l}+0.7(-0.57 \\
\text { to } 1.97)\end{array}$ & - & - & - & \\
\hline Zhu 2004 & $\begin{array}{l}\text { SU vs insulin and Chinese } \\
\text { medicine }\end{array}$ & 51 & $\begin{array}{l}+1.2 \%(0.25 \% \text { to } \\
2.1 \%)^{\star}\end{array}$ & - & $\begin{array}{l}+1.4(0.03 \\
\text { to } 2.77)^{\star}\end{array}$ & - & - & - & \\
\hline $\begin{array}{l}\text { Cabrera-Rode } \\
2002\end{array}$ & Insulin vs insulin and SU & 14 & - & - & $\begin{array}{l}-6.9(-2.0 \\
\text { to }-11.7)^{\star}\end{array}$ & - & $\begin{array}{l}+0.08 \\
(-0.15 \text { to } \\
0.3)\end{array}$ & - & \\
\hline Zhou 2005 & $\begin{array}{l}\text { Insulin vs insulin and } \\
\text { rosiglitazone }\end{array}$ & 17 & $+1.2 \%$ & $+1.4 \%$ & - & - & -0.4 & -1.1 & $\begin{array}{l}\text { Estimates based on median } \\
\text { values }\end{array}$ \\
\hline Davis 2005 & $\begin{array}{l}\text { Insulin and SU (FPG } \\
<15 \mathrm{mmol} / \mathrm{L})\end{array}$ & 235 & - & $0.4 \%$ & - & - & - & - & $\begin{array}{l}\text { Confidence intervals can } \\
\text { not be calculated }\end{array}$ \\
\hline Davis 2005 & $\begin{array}{l}\text { Insulin and SU (FPG }<15 \\
\mathrm{mmol} / \mathrm{L})\end{array}$ & 153 & - & $0.7 \%$ & - & - & - & - & $\begin{array}{l}\text { Confidence intervals can } \\
\text { not be calculated }\end{array}$ \\
\hline Davis 2005 & $\begin{array}{l}\text { Conventional treatment } \\
\text { and SU }\end{array}$ & 240 & - & $1.2 \%$ & - & - & - & - & $\begin{array}{l}\text { Confidence intervals can } \\
\text { not be calculated }\end{array}$ \\
\hline Davis 2005 & $\begin{array}{l}\text { Insulin and conventional } \\
\text { treatment }\end{array}$ & 195 & - & $0.9 \%$ & - & - & - & - & $\begin{array}{l}\text { Confidence intervals can } \\
\text { not be calculated }\end{array}$ \\
\hline Agardh 2005 & $\begin{array}{l}\text { Diamyd (GADA) (20 ug } \\
\text { or } 100 \text { ug or } 500 \text { ug) and } \\
\text { placebo/4 ug Diamyd }\end{array}$ & 47 & $\begin{array}{l}0.08 \%(0.4 \% \text { to } \\
0.7 \%)\end{array}$ & - & $\begin{array}{l}0.29(1.28 \\
\text { to } 2.4)\end{array}$ & - & - & - & \\
\hline
\end{tabular}




\begin{tabular}{|c|c|c|c|c|c|c|c|c|c|c|}
\hline 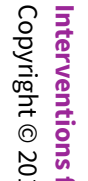 & $\begin{array}{l}\text { (Continued) } \\
\text { Maruyama } \\
2008\end{array}$ & Insulin vs SU & 60 & - & $\begin{array}{l}-0.5(-1.33 \\
\text { to } 0.33)\end{array}$ & - & $\begin{array}{l}-1.7 \\
(-3.59 \text { to } \\
0.19)\end{array}$ & - & - & \\
\hline 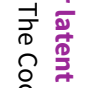 & Yang 2009 & SU or RSG & 29 & $\begin{array}{l}0.59(-0.18 \text { to } \\
1.36)\end{array}$ & $\begin{array}{l}1.43(-0.04 \\
\text { to } 2.9)\end{array}$ & - & - & - & - & \\
\hline 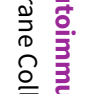 & Yang 2009 & $\begin{array}{l}\text { Insulin or Insulin+ rosigli- } \\
\text { tazone }\end{array}$ & 24 & $\begin{array}{l}2.01(0.15 \text { to } \\
3.87)\end{array}$ & $\begin{array}{l}0.48(-1.55 \\
\text { to } 2.51)\end{array}$ & - & - & - & - & \\
\hline 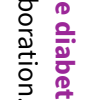 & Li 2009 & $\begin{array}{l}\text { Insulin vs insulin + Vitamin } \\
\text { D }\end{array}$ & 35 & - & - & - & - & $\begin{array}{l}100 \\
\mathrm{pmol} / \mathrm{L}\end{array}$ & - & $\begin{array}{l}\text { Confidence intervals can } \\
\text { not be calculated }\end{array}$ \\
\hline 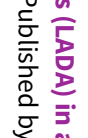 & Xu 2008 & Insulin vs insulin + TYK & 74 & $\begin{array}{l}0.06(-0.18 \text { to } \\
0.30)\end{array}$ & - & $\begin{array}{l}-0.18 \\
(-0.83 \text { to } \\
0.47)\end{array}$ & - & $\begin{array}{l}0.07 \\
(-0.05 \text { to } \\
0.19)\end{array}$ & - & $\begin{array}{l}\text { All measures at } 3 \text { months } \\
\text { follow-up }\end{array}$ \\
\hline 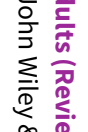 & $\begin{array}{l}\text { Thunander } \\
2010\end{array}$ & $\begin{array}{l}\text { Insulin vs conventional } \\
\text { treatment (diet } \pm \mathrm{OHA} \text {, } \\
\text { metformin, and/or SU) }\end{array}$ & 37 & $\begin{array}{l}0.4(-0.38 \text { to } \\
1.18)\end{array}$ & $\begin{array}{l}-0.3(-0.44 \\
\text { to } 1.04)\end{array}$ & - & - & - & - & $\begin{array}{l}\text { Stimulated C-peptide only } \\
\text { reported }\end{array}$ \\
\hline 告 & $\begin{array}{l}\text { Footnotes } \\
\text { FCP: fasting }\end{array}$ & ptide; FPG: fasting plasma g & $\lambda \cos \theta$ & : glycosylated & noglobin A1c & SU : sulph & lurea & & & \\
\hline
\end{tabular}




\section{WHAT'S NEW}

\begin{tabular}{lll}
\hline Date & Event & Description \\
\hline 30 March 2011 & $\begin{array}{l}\text { New citation required but conclusions } \\
\text { have not changed }\end{array}$ & Update of the review first published in issue 3,2007 \\
\hline 30 March 2011 & New search has been performed & $\begin{array}{l}\text { Six new manuscripts and meta-analysis for one outcome (HbA1c) } \\
\text { have been added. }\end{array}$ \\
\hline
\end{tabular}

\section{CONTRIBUTIONSOF AUTHORS}

SINEAD BROPHY, HELEN DAVIES, HUW BRUNT AND SOPNA MANNAN have contributed to the protocol development.

SINEAD BROPHY, and HELEN DAVIES have undertaken the trial selection (performed by two authors independently), data review, data entry and production of the final review for this update. HUW BRUNT AND SOPNA MANNAN contributed to data review and production of the first review in 2006

RHYS WILLIAMS has provided supervision, and contributed to protocol development, data review (as adjudicator), and production of the final review.

\section{DECLARATIONSOF INTEREST}

SB was lead investigator on an RCT in LADA examining insulin compared to tablet treatment. This trial is now terminated.

\section{SOURCES OF SUPPORT}

\section{Internal sources}

- Swansea University, UK.

\section{External sources}

- BUPA Foundation, UK.

- National Public Health Service, UK.

\section{DIFFERENCES BETWEEN PROTOCOL AND REVIEW}

\begin{tabular}{ll}
\hline Section & Changes \\
\hline Background & Addition of information on glutamic acid decarboxylase (GAD) testing. \\
\hline Objectives & "assess affects" removed. \\
\hline Type of studies & $\begin{array}{l}\text { Protocol stated we would consider longitudinal prospective designs. However, we have removed } \\
\text { this option in the review. }\end{array}$ \\
\hline Primary outcome measure & Time to insulin has been added in line with authors' comments. \\
\hline Conflict of interests & No declarations of conflict of interest \\
\hline
\end{tabular}

\section{NDEX TERMS}

\section{Medical Subject Headings (MeSH)}

Autoimmune Diseases [ ${ }^{\star}$ drug therapy] [immunology]; Diabetes Mellitus, Type 2 [ ${ }^{\star}$ drug therapy] [immunology]; Drugs, Chinese Herbal [therapeutic use]; Glutamate Decarboxylase [therapeutic use]; Glycated Hemoglobin A [metabolism]; Hypoglycemic Agents 
[*therapeutic use]; Insulin [therapeutic use]; Metformin [therapeutic use]; Randomized Controlled Trials as Topic; Sulfonylurea Compounds [therapeutic use]; Thiazolidinediones [therapeutic use]

\section{MeSH check words}

Adult; Humans 